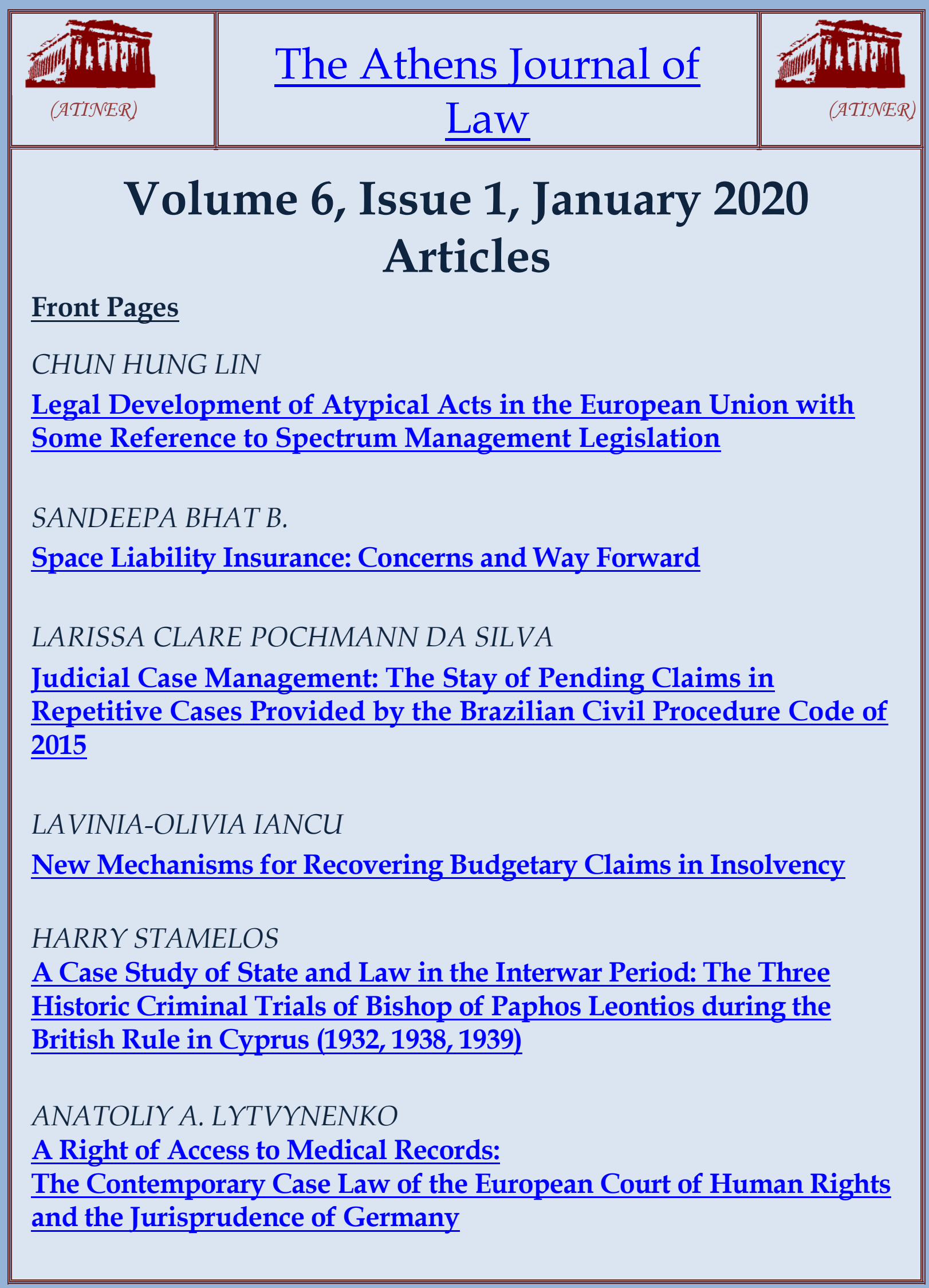




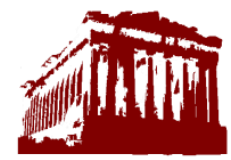

(ATINER)

\section{Mission}

ATINER is a World Non-Profit Association of Academics and Researchers based in Athens. ATINER is an independent Association with a Mission to become a forum where Academics and Researchers from all over the world can meet in Athens, exchange ideas on their research and discuss future developments in their disciplines, as well as engage with professionals from other fields. Athens was chosen because of its long history of academic gatherings, which go back thousands of years to Plato's Academy and Aristotle's Lyceum. Both these historic places are within walking distance from ATINER's downtown offices. Since antiquity, Athens was an open city. In the words of Pericles, Athens"... is open to the world, we never expel a foreigner from learning or seeing". ("Pericles' Funeral Oration", in Thucydides, The History of the Peloponnesian War). It is ATINER's mission to revive the glory of Ancient Athens by inviting the World Academic Community to the city, to learn from each other in an environment of freedom and respect for other people's opinions and beliefs. After all, the free expression of one's opinion formed the basis for the development of democracy, and Athens was its cradle. As it turned out, the Golden Age of Athens was in fact, the Golden Age of the Western Civilization. Education and (Re)searching for the 'truth' are the pillars of any free (democratic) society. This is the reason why Education and Research are the two core words in ATINER's name. 
The Athens Journal of Law

ISSN NUMBER: 2407-9685 - DOI: 10.30958/aj1

Volume 6, Issue 1, January 2020

Download the entire issue $(\underline{\mathrm{PDF}})$

Front Pages

i-viii

Legal Development of Atypical Acts in the European

9

Union with Some Reference to Spectrum Management Legislation

Chun Hung Lin

Space Liability Insurance: Concerns and Way Forward

Sandeepa Bhat B.

Judicial Case Management: The Stay of Pending

Claims in Repetitive Cases Provided by the Brazilian

Civil Procedure Code of $\mathbf{2 0 1 5}$

Larissa Clare Pochmann Da Silva

New Mechanisms for Recovering Budgetary Claims in

Insolvency

Lavinia-Olivia Iancu

A Case Study of State and Law in the Interwar Period:

The Three Historic Criminal Trials of Bishop of Paphos

Leontios during the British Rule in Cyprus $(1932,1938$, 1939)

Harry Stamelos

A Right of Access to Medical Records:

The Contemporary Case Law of the European Court of

Human Rights and the Jurisprudence of Germany

Anatoliy A. Lytoynenko 


\section{Athens Journal of Law Editorial and Reviewers' Board}

$\underline{\text { Editors }}$

- Dr. David A. Frenkel, LL.D., Adv., FRSPH(UK), Head, Law Research Unit, ATINER, Emeritus Professor, Law Area, Guilford Glazer Faculty of Business and Management, Ben-Gurion University of the Negev, BeerSheva, Israel.

- Dr. Michael P. Malloy, Director, Business and Law Research Division, ATINER \& Distinguished Professor \& Scholar, University of the Pacific, USA.

\section{Editorial Board}

- Dr. Viviane de Beaufort, Professor, ESSEC Business School, France.

- Dr. Dane Ally, Professor, Department of Law, Tshwane University of Technology, South Africa.

- Dr. Jagdeep Bhandari, Professor, Law department, Florida Coastal School of Law, USA.

- Dr. Mpfari Budeli, Professor, University of South Africa, South Africa.

- Dr. J. Kirkland Grant, Distinguished Visiting Professor of Law, Charleston School of Law, USA.

- Dr. Ronald Griffin, Academic Member, ATINER \& Professor, Washburn University, USA.

- Dr. Guofu Liu, Professor of Migration Law, Beijing Institute of Technology, China.

- Dr. Rafael de Oliveira Costa, Public Prosecutor, Researcher \& Professor, Ministério Público do Estado de São Paulo Institution, Brazil.

- Dr. Damian Ortiz, Prosecutor \& Professor, the John Marshall Law School, USA.

- Dr. Dwarakanath Sripathi, Professor of Law, Osmania University, India.

- Dr. Robert W. McGee, Associate Professor of Accounting, Fayetteville State University, USA.

- Dr. Nataša Tomić-Petrović, Associate Professor at Faculty of Transport and Traffic Engineering, University of Belgrade, Serbia.

- Dr. Emre Bayamlioğlu, Assistant Professor, Koç Universty, Faculty of Law, Turkey.

- Dr. Thomas Philip Corbin Jr., Assistant Professor, Department of Law, Prince Mohammad Bin Fahd University, Saudi Arabia.

- Dr. Mahfuz, Academic Member, ATINER \& Assistant Professor- Head, Department of Law, East West University, Bangladesh.

- Dr. Taslima Yasmin, Assistant Professor, Department of Law, University of Dhaka, UK.

- Dr. Margaret Carran, Senior Lecturer, City University London, UK.

- Dr. Maria Luisa Chiarella, Academic Member, ATINER \& Senior Lecturer, Magna Graecia University of Catanzaro, Italy.

- Dr. Anna Chronopoulou, Academic Member, ATINER \& Senior Lecturer, European College of Law, UK.

- Dr. Antoinette Marais, Senior Lecturer, Tshwane University of Technology, South Africa.

- Dr. Elfriede Sangkuhl, Senior Lecturer, University of Western Sydney, Australia.

- Dr. Demetra Arsalidou, Lecturer, Cardiff University, UK.

- Dr. Nicolette Butler, Lecturer in Law, University of Manchester, UK.

- Dr. Jurgita Malinauskaite, Lecturer in Law, Brunel University London \& Director of Research Degrees, Arts and Social Sciences Department of Politics-History and Law, College of Business, UK.

- Dr. Paulius Miliauskas, Lecturer, Private Law Department, Vilnius University, Lithuania.

- Dr. Jorge Emilio Núñez, Lecturer in Law, Manchester Law School, Manchester Metropolitan University, UK.

- Dr. Ibrahim Sule, Lecturer, University of Birmingham, UK.

- Dr. Isaac Igwe, Researcher, London University, UK.

- Regina M. Paulose, J.D, LLM International Crime and Justice.

- General Managing Editor of all ATINER's Publications: Ms. Afrodete Papanikou

- ICT Managing Editor of all ATINER's Publications: Mr. Kostas Spyropoulos

- Managing Editor of this Journal: Ms. Eirini Lentzou (bio)

\section{Reviewers' Board}

Click Here 


\section{President's Message}

All ATINER"s publications including the e-journals are open access without any costs (submission, processing, publishing, open access paid by authors, open access paid by readers etc) and are independent of the presentations made at any of the many small events (conferences, symposiums, forums, colloquiums, courses, roundtable discussions) organized by ATINER throughout the year. The intellectual property rights of the submitted papers remain with the author.

Before you submit, please make sure your paper meets some basic academic standards, which include proper English. Some articles will be selected from the numerous papers that have been presented at the various annual international academic conferences organized by the different divisions and units of the Athens Institute for Education and Research.

The plethora of papers presented every year will enable the editorial board of each journal to select the best ones, and in so doing, to produce a quality academic journal. In addition to papers presented, ATINER encourages the independent submission of papers to be evaluated for publication.

The current issue of the Athens Journal of Law (AJL) is the first issue of the sixth volume (2020).

Gregory T. Papanikos, President

Athens Institute for Education and Research 


\section{Athens Institute for Education and Research}

A World Association of Academics and Researchers

\section{$1^{\text {th }}$ Annual International Conference on Law \\ 13-16 July 2020, Athens, Greece}

The Law Unit of ATINER, will hold its 17th Annual International Conference on Law, 13-16 July 2020, Athens Greece sponsored by the Athens Journal of Law. The aim of the conference is to bring together academics and researchers from all areas of law and other related disciplines. You may participate as panel organizer, presenter of one paper, chair a session or observer. Please submit a proposal using the form available (https:/ / www.atiner.gr/2020/FORM-LAW.doc).

\section{Academic Members Responsible for the Conference}

- Dr. David A. Frenkel, LL.D., Head, Law Unit, ATINER \& Emeritus Professor, Law Area, Guilford Glazer Faculty of Business and Management, Ben-Gurion University of the Negev, Beer-Sheva, Israel.

- Dr. Michael P. Malloy, Director, Business, Economics and Law Division, ATINER \& Distinguished Professor \& Scholar, University of the Pacific, USA.

- Abstract Submission: 16 March 2020

\section{Important Dates}

- Acceptance of Abstract: 4 Weeks after Submission

- Submission of Paper: 15 Iune 2020

\section{Social and Educational Program}

The Social Program Emphasizes the Educational Aspect of the Academic Meetings of Atiner.

- Greek Night Entertainment (This is the official dinner of the conference)

- Athens Sightseeing: Old and New-An Educational Urban Walk

- Social Dinner

- Mycenae Visit

- Exploration of the Aegean Islands

- Delphi Visit

- Ancient Corinth and Cape Sounion

- More information can be found here: https://www.atiner.gr/social-program

\section{Conference Fees}

Conference fees vary from $400 €$ to $2000 €$

Details can be found at: https://www.atiner.gr/2019fees 


\section{Athens Institute for Education and Research}

\section{A World Association of Academics and Researchers}

\section{$7^{\text {th }}$ Annual International Conference on Business, Law \& Economics \\ 4-7 May 2020, Athens, Greece}

The Business, Economics and Law Division (BLRD) of ATINER is organizing its $7^{\text {th }}$ Annual International Conference on Business, Law \& Economics, 4-7 May 2020, Athens, Greece, sponsored by the Athens Journal of Business \& Economics and the Athens Journal of Law. In the past, the six units of BLRD have organized more than 45 annual international conferences on accounting, finance, management, marketing, law and economics. This annual international conference offers an opportunity for cross disciplinary presentations on all aspects of business, law and economics. This annual international conference offers an opportunity for cross disciplinary presentations on all aspects of business, law and economics. Please submit an abstract (email only) to: atiner@atiner.gr, using the abstract submission form (https://www.atiner.gr/2020/FORM-BLE.doc)

\section{Important Dates}

- Abstract Submission: 6 January 2020

- Acceptance of Abstract: 4 Weeks after Submission

- Submission of Paper: 6 April 2020

\section{Academic Member Responsible for the Conference}

- Dr. Gregory T. Papanikos, President, ATINER.

- Dr. Michael P. Malloy, Director, Business, Economics and Law Division, ATINER \& Distinguished Professor \& Scholar, University of the Pacific, USA.

- Dr. David A. Frenkel, LL.D., Head, Law Research Unit, ATINER \& Emeritus Professor, Law Area, Guilford Glazer Faculty of Business and Management, Ben-Gurion University of the Negev, Beer-Sheva, Israel.

\section{Social and Educational Program}

The Social Program Emphasizes the Educational Aspect of the Academic Meetings of Atiner.

- Greek Night Entertainment (This is the official dinner of the conference)

- Athens Sightseeing: Old and New-An Educational Urban Walk

- Social Dinner

- Mycenae Visit

- Exploration of the Aegean Islands

- Delphi Visit

- Ancient Corinth and Cape Sounion

More information can be found here: https://www.atiner.gr/social-program

\section{Conference Fees}

Conference fees vary from $400 €$ to $2000 €$

Details can be found at: https://www.atiner.gr/2019fees 


\title{
Legal Development of Atypical Acts in the European Union with Some Reference to Spectrum Management Legislation ${ }^{1}$
}

\author{
By Chun Hung Lin ${ }^{*}$
}

\begin{abstract}
The article focuses on the issue of Atypical Acts in the European Union. For facing internal and external challenges, the EU had to adjust its legal framework with a more flexible way but a binding nature. Meanwhile, atypical acts were a category of acts adopted by the European institutions. Since some standard legislative instruments could be lengthy and rigid, many EU institutions use non-standard instruments, atypical acts, as a way to obtain greater flexibility in the lead up to legislation or flanking legislative activity. This article will bring some references of spectrum management within the EU's internal legal order and its external relations to discuss the atypical acts of the $E U$.
\end{abstract}

Keywords: Atypical Acts; European Union; Spectrum Management; Treaty on the Functioning of the European Union; Transparency

\section{Introduction}

It had been a challenging time for the European Union (EU) because those internally, important, even fundamental decisions were on the agenda as its struggled with the Euro crisis and its underlying economic fissures since 2010. For facing those changes, the EU had to adjust its legal framework with a more flexible way but a binding nature. Meanwhile, atypical acts were a category of acts adopted by the European institutions. Because the adoption of the standard legislative instruments lay down in the Treaty on the Functioning of the European Union (TFEU) can prove lengthy and rigid, those EU institutions thus use nonstandard instruments, atypical acts, as a way to obtain greater flexibility in the lead up to legislation or flanking legislative activity. These acts are not part of legal acts provided for by the TFEU Arts. 288 to 292. Some atypical acts are provided for by other provisions of TFEU, while others have been developed by institutional practice. Atypical acts are differentiated by their application, which is generally political. Some of them are binding, but this remains limited to the EU's institutional framework.

Atypical acts may also relate to the EU internal organization or have a more general application on specific policy areas. Each of EU institutions has developed

\footnotetext{
*Professor of Law, Graduate Institute of Financial \& Economic Law, Feng Chia University, Taichung, Taiwan. Emails: chunhlin@fcu.edu.tw - and - jasonlin626@yahoo.com.tw.

${ }^{1}$ I would like to thank for the financial support from Institute of European and American Studies, Academia Sinica. Any errors remain solely mine.
} 
a series of instruments in the context of its own activity. These acts essentially express the institutions' opinion on certain European or international issues. They have general application but may not have binding effects. Atypical acts may also contribute significantly to the legislative and policy process and may yield additional beneficial effects like enhancement of information and transparency, or promotion of public functions. Atypical acts are also common in the external trade relations of the EU.

This article discusses atypical acts of the EU concerning spectrum management within the EU's internal legal order and its external relations. Due to the increase of spectrum demands and the shortage of radio frequencies, issues relating to the establishment of international arrangement of spectrum use have become one of the most important tasks in many countries. On the other hand, current legislations and legal enforcements are insufficient to fit the future legal demands for spectrum management and face difficult challenges. Therefore, how to speed up the legislation and utilise specific political norms to establish suitable regulations for spectrum management now enters a new century both technically and practically. The management and legislation of spectrum resources involves performing many different activities and develops into different models. Different spectrum management approaches are required to deal with the distinct needs of individual radio users and the time period that a frequency band may be open for administrative reviews. For this purpose, the EU had adopted some specific means for spectrum management.

Like more formal conduct of trade relations by means of international agreement. The less formal character of these acts often allows them to be more policy-driven and so makes it easier to address key political concerns relevant for EU external trade relations in a more flexible and current manner. While atypical acts are most commonly associated with internal EU legislation under TFEU, this research sets out to examine the functions and effects of atypical acts and its legal development in the EU. This research hopes to provide knowledge and concrete suggestions concerning the issue of atypical acts in EU. The troubles associated with the use of atypical acts were highlighted in particular by the multilateral negotiations and enforcement of spectrum management legislation. Based on the comparative analysis of the role of atypical acts in the EU's internal legislation and external action for spectrum management, this research explores possibilities of limiting the drawbacks while preserving the benefits of the use of atypical acts in external policies. The article is accordingly structured in some parts, the forms and functions of atypical acts in the EU's internal legislation and the rules governing the use of atypical acts or in the patterns of their practical use by the EU institutions. Based on the discussion of the role and legal development of atypical acts, this article then explores the drawbacks and benefits of the use of atypical acts in spectrum management and its future development. 


\section{Role of Atypical Acts in EU Law}

\section{Atypical Acts and Sources of European Union Law}

The European law, unlike some of its member states' legal systems, does not clearly distinguish between public and private law. The structures of EU law have developed in an evolutionary fashion which is most visible in the development of the different forms in EU law. ${ }^{2}$ Generally speaking, there are three sources of EU law: primary law, secondary law and supplementary law. The sources of primary law come mainly from the founding Treaties, TFEU. These Treaties set out the distribution of competences between the EU and its member states and establishes the legal frameworks and powers of the European institutions. Secondary sources are legal instruments also based on the Treaties and include unilateral acts as well as conventions and agreements. Supplementary sources are elements of law not provided for by the Treaties which includes Court of Justice case law, international law and general principles of law, etc.

As one of the secondary sources, unilateral acts can be divided into two categories including those listed in TFEU Art. 288, and not listed in TFEU Art. 288. Those listed in TFEU Art. 288 include regulations, directives, decisions, and opinions, etc. The other comprises so-called "atypical acts" such as communications, recommendations, as well as white and green papers, etc. Through unilateral acts, individual rights are conferred by the institutions acting in an entirely autonomous manner. Increasingly, the use of unilateral forms of act for the implementation of EU law is supplemented with forms of acts, which reflect nonhierarchical relations in the EU's network of "integrated administration." Moreover, the unilateral acts adopted by the European institutions are subject to be reviewed by the European Court of Justice. Along with conventions and agreements, they constitute the secondary legislation of the EU.

Under the terms of the principle of conferral, acts should have a legal basis in the TFEU corresponding to the field in which the European institutions wish to take action. However, TFEU Art. 289 establishes a distinction between legislative acts, namely those adopted following a legislative procedure, and acts which are, by default, non-legislative. The aim of non-legislative acts is to implement legislative acts or certain specific provisions from the Treaties effectively. For example, legislative acts must be published in the European Official Journal and parties to whom an act is addressed may also be informed, as is the case with decisions. As a rule, those acts enter into force on the day they are notified or published in the Official Journal. Exceptionally, non-legislative may enter into force on the 20th day following that of their publication. They may also provide for implementation on a date later than that of their entry into force.

For policy and economic purposes, the Treaties had designed the European institutions may choose the act that they deem most appropriate for implementing their policy and law. For example, where policies are designed to have an incentive effect, the Council or the Commission may opt for a recommendation.

\footnotetext{
${ }^{2}$ Hofmann (2006).

${ }^{3}$ Hofmann \& Türk (2006).
} 
For atypical acts, the EU institutions use this type of non-standard instruments as a way to obtain greater flexibility for legislation purpose or legislative activity. For example, some atypical acts are designed to cite the instruments conferring the power to adopt them in citations beginning with "having regard to" and to state the reasons on which they are based.

\section{Meaning of Atypical Acts}

As stated above, there has been great creativity in the development of forms of act for the implementation of law in different policy areas and in secondary law. ${ }^{4}$ Amongst these evolutionary developments is an increase in the use of atypical acts. Atypical acts are a category of act adopted by the European institutions and relate to EU's internal organization with a more general application on specific policy areas. Under the TFEU Art. 288, the institutions shall adopt regulations, directives, decisions, recommendations and opinions which might process under certain rules with some degrees of binding capacity. Those proceeding had shown that the adoption of the standard legislative instruments could be lengthy and rigid. However, unlike what this wording seems to suggest, the EU decision making is not limited to the types of acts expressly listed in TFEU Art. 288. ${ }^{5}$ Thus these acts are described as "atypical" because they are not part of the nomenclature of legal acts provided for by the TFEU Art. 288 to $292{ }^{6}$

The use by the European institutions of atypical acts that are legal instruments other than those provided for in the Treaty is a well-known practice. Their existence is recognised indirectly by the draft constitutional Treaty in its Art.I32(2) which states: "when considering proposals for legislative acts, the European Parliament and the Council of Ministers shall refrain from adopting acts not provided for by this Article in the area in question." Even in the event of such a limitation being accepted by the intergovernmental conference, however, there would be no consequences for the most well-known and widely studied form of atypical acts, a kind of communications of the Commission. ${ }^{7}$

There is a wide variety of atypical acts. Many of them are differentiated by their application, which are generally political or economic oriented ones. Some may be binding, but this remains limited to the EU's institutional framework. Some are provided for by other provisions of the EU founding treaties, while others have been developed by institutional practice. For example, they relate to resolutions, conclusions, communications, etc. These acts have a political application, but they may not be generally legally binding. The distinction between

\footnotetext{
${ }^{4}$ Hofmann (2006).

${ }^{5}$ See Case 22/70, Commission of the European Communities v. Council of the European Communities (1971); Case 59/75, Pubblico Ministero v. Flavia Manghera and others (1976) and Case 294/83, Parti écologiste 'Les Verts' v. European Parliament..

${ }^{6}$ See Lenaerts \&Van Nuffel (2005).See also Bieber \& Salomé (1996) at 921; Cairns (2002) at 79; Klabbers (1994) at 997.

${ }^{7}$ Snyder (1994).
} 
typical and atypical acts does not coincide with the issue of their character as legally binding or not, but both may in principle contain hard as well as soft law. ${ }^{8}$

These are forms of act which are not unilaterally set but which are the result of a negotiation between various parties. For example, they relate to the internal regulations of institutions, certain Council decisions, measures adopted by the Commission in the field of competition, telecommunication, consumer protection, etc. It is because the Commission uses atypical acts as legal steering instruments to provide legal instructions to firms, national authorities, or courts. The less formal and legal character of these acts often allows them to be more policy-driven and makes it easier to address key political concerns in a more flexible and current manner. ${ }^{9}$

\section{Types of Atypical Acts}

\section{Atypical Acts provided for by the Treaties}

In fact, the catalogue of decision making instruments available to EU institutions is open. There are certain acts other than those mentioned in TFEU Art. 288 are referred to in various sections of the Treaty. These acts are essentially intended to facilitate work and cooperation between the institutions. For example, in the context of the procedure for the adoption of international agreements, the Council must send negotiating guidelines to the Commission for the negotiation of the agreements. Under TFEU Art. 121(2), 148(2), 171(1), and 218(2), there are guidelines and guiding directives defined for the institutions used such as Guidelines on the application of Article 81 of the EU Treaty to technology transfer agreements, OJ (2004) C 101/2; Guidelines on Vertical Restraints, OJ (2000) C 291/1; Guidelines on the applicability of Article 81 of the EU Treaty to horizontal cooperation agreements, OJ (2001) C 3/2, etc.

The founding Treaties also provide for other types of act adopted in the context of political dialogue among EU institutions. Under TFEU Arts. 177, 287(3), and 295, the EU institutions may also go further by organizing their cooperation by means of inter-institutional agreements. The EU legislators including European Parliament, the Council and the Commission need to consult each other by common agreement and make arrangements for their cooperation and conclude inter-institutional agreements in compliance with the Treaties. ${ }^{10}$ These types of agreements are also atypical acts and may have binding effect, but only for the institutions which have signed the agreements. Under the Lisbon Treaty and TFEU Art. 295, however, it seems the Treaties did not explicitly encourage EU institutions to conclude inter-institutional agreements. ${ }^{11}$ In addition, rules of procedure are also one type of atypical acts, as the EU institutions' Rules of Procedure are atypical acts. The founding Treaties provide that EU institutions shall adopt their own Rules of Procedure under TFEU Art. 232, 240, 254, 256, 287

\footnotetext{
${ }^{8}$ Cosma \& Whish (2003). See also Thurer (1990) and Klabbers (1998).

${ }^{9}$ Ruse-Khan, Jaeger \& Kordic (2010).

${ }^{10}$ TFEU Article 295.

${ }^{11}$ Weiler (2010).
} 
and 306. ${ }^{12}$ The Rules of Procedure lay down the organization, operation and internal rules of procedure of the EU institutions. They have binding effects only for the institutions concerned. Some of these Treaty-based authorizations for action will in practice, however, be exercised in the form of a decision in the sense of TFEU Art. $288 .^{13}$

Under TFEU, there are some types of atypical acts aimed for economic or financial regulations, especially those acts request prompt and decisive responses. For example, Conclusions could be made by the Council on the broad guidelines of the economic policies for the EU; ${ }^{14}$ and also Incentive Measures, was regulated under the Parliament and the Council to encourage cooperation between member states and to support their action in the field of employment through initiatives aimed at developing exchanges of information and best practices. ${ }^{15}$ Under TFEU Arts 126(4), 127(4), 132(1), and 134(1), Opinions may be delivered by the European Central Bank or some specified committee at the request of the Council or of the Commission, or on its own initiative for submission to those institutions, to keep under review the economic and financial situation of the member states. ${ }^{16}$

\section{Atypical Acts not provided for by the Treaties}

Each of EU institutions has developed a series of instruments in the context of its own activity. For example, the European Parliament expresses some of its political positions at international level by means of resolutions or declarations. Similarly, the Council regularly adopts conclusions, resolutions or guidelines following its meetings. These acts essentially express the institutions' opinion on certain European or international issues. They have general application but do not have binding effects and may not be defined by the founding Treaties. Binding character concerning the substance of the atypical act has been confirmed in respect of codes of conduct, letters, or general communications issued by the legislators, the Commission and the Council. ${ }^{17}$ Some instruments including declarations, deliberations, resolutions, communications, codes of conduct, timetables, conclusions, notices ${ }^{18}$, etc. had developed into different norms as atypical acts.

Moreover, there are "White Papers" and "Green Papers" which aim to facilitate the adoption of subsequent legal instruments either by engendering

\footnotetext{
${ }^{12}$ TFEU Art. 15. (ex TEC Art. 255).

${ }^{13}$ See Lenaerts \& Van Nuffel (2005) at 17-140.

${ }^{14}$ TFEU Arts 121 and 148(1).

${ }^{15}$ TFEU Arts 19(2), 149, 165(4), 167(5), and 168(4)(c).

${ }^{16}$ Petit \& Rato (2008).

${ }^{17}$ See Case C-57/95, Commission v. France (1997); Case C-325/91, France v. Commission (1993) and see Case 22/70, Commission v. Council (1971).

${ }^{18}$ See Commission Notice on immunity from fines and reduction of fines in cartel cases; Commission Notice on Cooperation within the Network of Competition Authorities; Commission Notice on Cooperation between the Commission and the Courts of the EU Member States in the application of Articles 81 and 82 EC, OJ (2004) C 101/54; Commission Notice on Informal Guidance relating to Novel Questions concerning Articles 81 and 82 of the EU Treaty that arise in Individual Cases (Guidance Letters); Commission Notice on the Handling of Complaints by the Commission under Articles 81 and 82 of the EU Treaty.
} 
debate on the issues at stake or detailing the proposals of the Commission. The Commission adopts green papers which are intended to launch public consultations on certain European issues, such as telecommunication service, antitrust, ${ }^{19}$ consumer protection, ${ }^{20}$ etc. It uses these to gather the necessary information before drawing up a legislative proposal. The purpose of a Green Paper is to foster a debate on a special topic in which it aims to set out a number of issues connected with it and intends to launch a consultation on these issues. ${ }^{21}$ Green Papers usually start with an overview of the present situation and regulatory framework. Following the results of the green papers, the Commission sometimes adopts White Papers setting out detailed proposals for European action. ${ }^{22}$ White Papers constitute documents for discussion and also aim at laying down the main lines or strategy of action for the future. ${ }^{23}$ For detailed implementation and interpretation of Green and White papers, the EU legislators may also adopt some acts by way of Staff Working Papers, ${ }^{24}$ Consultation Papers, ${ }^{25}$ Documents, ${ }^{26}$ or even Letters. ${ }^{27}$ For spectrum management, there are some Staff Working Papers accompanying the Commission Communication on Scientific Information in the Digital Age: Access, Dissemination and Preservation. ${ }^{28}$ The European Commission publishes different documents in order to launch a debate on the need for Community action in a specific field, and Staff Working Papers analyse those issues in more depth, indicating the next steps that could be taken. ${ }^{29}$ By offering some options as a solution, as in Green Papers, Staff Working Documents show the viewpoints in favour of or against a certain measure of the interested parties in a specific field. ${ }^{30}$

\footnotetext{
${ }^{19}$ See Green Paper on damages actions for breach of the EU antitrust rules.

${ }^{20}$ See Green Paper on European Union Consumer Protection; See also Green Paper on the Review of the Consumer Acquits.

${ }^{21}$ Green Paper on Copyright in the Knowledge Economy; Green Paper on the Protection of Utility Models in the Single Market at II et seq.

${ }^{22}$ See White Paper on damages actions for breach of the EU antitrust rules; White Paper on the review of Regulation 4056/86, applying the EU competition rules to maritime transport; See also White Paper on the modernization of the rules implementing Articles 85 and 86 of the EU Treaty Commission Program No 99/027.

${ }^{23}$ See, e.g., the White Paper, Completing the Internal Market, which states its function as a followup at 117, to the Green Paper, on the establishment of the common market for broadcasting, especially by satellite and cable.

${ }^{24}$ Commission Staff Working Paper accompanying the White Paper on damages actions for breach of the EU antitrust rules.

${ }^{25}$ DG Competition discussion paper on the application of Article 82 of the Treaty to exclusionary abuses.

${ }^{26}$ See Explanatory brochure for Commission Regulation 1400/2002 of 31 July 2002.

${ }^{27}$ See Case C-313/90, Comité International de la Rayonne et des Fibres Synthétiques and others v. Commission of the European Communities (1993).

${ }^{28}$ See Staff working papers accompanying the Commission Communication on scientific information in the digital age: access, dissemination and preservation.

${ }^{29}$ Commission Staff Working Document, Media pluralism in the Member States of the European Union.

${ }^{30}$ See submissions by the music industry and interested parties in the Commission staff working document, Impact assessment reforming cross-border collective management of copyright and related rights for legitimate online music services.
} 
The Commission also adopts several atypical acts in the form of Communications for new policy programs. Some scholar had distinguished certain categories of Communications addressed to the EU Council, the European Parliament and more generally the other institutional actors. ${ }^{31}$ For examples, there are some Communications used for spectrum management such as the Commission Recommendation on Relevant Product and Service Markets within the Electronic Communications Sector susceptible to ex ante regulation in accordance with Directive 2002/21/EC of the European Parliament and of the Council on a common regulatory framework for electronic communications networks and services, $\operatorname{COM}(2007) 5406$ as well as the Report from the Commission to the Council and the European Parliament Evaluation Report on the application of the Council Regulation (EC) No 994/98 of 7 May 1998 regarding the application of Articles 87 and 88 (ex-Article 93) of the EU Treaty to certain categories of horizontal State aid, pursuant to Article 5 of this Regulation, $\operatorname{COM}(2006) 0831$ final.

Those Communications may function for different purposes. For example, there are "Informative Communications" which are produced in application of secondary legislation and aim to inform economic operators of an event likely to affect their situation. ${ }^{32}$ The Communications may also be termed "purely interpretative", as their aim is merely to express the Commission's interpretation of EU law. Such instruments are adopted in areas where the member states are in charge of the implementation of EU law, in order to help national administrations perform this task, but also in order to make natural and legal persons aware of their rights. ${ }^{33}$ This information shall assist administrative institutions as well as the public in assessing the scope, effects and implications of the EU law. Those Communications make explicit the policy of the Commission with regard to areas where it is empowered either by the treaty or by secondary legislation to decide on individual cases. ${ }^{34}$ Such instruments are adopted in areas for which the Commission has discretionary power in order to provide guidance to operators as to the way the Commission intends to use its discretion such as information technology and spectrum management, etc.

\section{Functions of Atypical Acts}

The type of atypical acts affords a relatively greater degree of flexibility as regards both the formal process for their adoption and the intensity of their legal effects. Particularly, for the Commission, the steering instruments show several regulatory advantages and thus are attractive for EU regulators.

\section{Steering Effect and Flexibility}

\footnotetext{
${ }^{31}$ Melchior (1979) at 248.

${ }^{32}$ Melchior (1979) at 244.

${ }^{33}$ Lefevre (2004).

${ }^{34}$ Meesen (1997) at 103.
} 
There is some non-binding or non decision-type of atypical acts which are not completely devoid of effects and are functioned for public consultations by the Commission over changes in enforcement policies in a given field; some are seeking the behavioural guidance as an alternative to formal legislation or informing third parties of how certain Treaty provisions will be interpreted and applied and how discretion will be used. ${ }^{35}$ As regards steering potential in particular, atypical acts allow for a carefully tailored differentiation of those effects on the part of the addressees, affording space for both the adopting institutions in terms of self-binding effect and intensity of enforcement and the addressees in terms of compliance. ${ }^{36}$ These steering effects in favour of prevention and enforcement cannot similarly be achieved by any of the classical legal instruments laid down in TFEU Art. 288 because of the defined legal effects characteristics associated with those explicit forms of actions. ${ }^{37}$ Therefore, atypical acts are one of an excellent instrument for institutions to prepare the launch of new policies and test their impact. ${ }^{38}$

Moreover, the advantages of atypical acts compared to standard TFEU Art. 288 instruments include the essentially greater flexibility by lowering the formal requirements and enhancing quality throughout the adoption process and in the differentiation of legal effects and enforcement and transparency. Some law instruments may even allow institutions an opportunity to act outside their statutory competences. Such an adoption typically requires only compliance with the internal procedures for decision making or the rules on official representation within the institution involved. In addition, they are not subject to mandatory publication in the Official Journal under TFEU Art. 297. ${ }^{39}$ Those advantages include reducing costs, speeding up decision making and reform, and reducing backlog. ${ }^{40}$

\section{Implementation of EU Law}

The uses of atypical acts are practically important and frequently used for implementation of EU law. If an institution wishes to act in the form of act provided by the Treaties, it will need to have the competence to act in the specific area. If a certain form of act is explicitly required in primary or secondary legislation, it will be obliged to use that type of act. In the absence of provisions specifying the necessary form of act, the institutions then have to decide whether to use the atypical acts. The EU institutions and member states as well as private actors then interact to create the methods for implementation of EU law and call for the development of flexible forms of acts to establish the new legal regime.

Even in the absence of a specific legal provision, EU law contains, implicitly or explicitly, rules and principles governing the use of certain forms of acts for

\footnotetext{
${ }^{35}$ Cosma \& Whish (2003) at 36.

${ }^{36}$ Rudloff \& Simons (2006) at 169.

${ }^{37}$ Petit \& Rato (2008).

${ }^{38}$ Cini (2000).

${ }^{39}$ See Cosma \& Whish (2003) at 34; See also Case C-322/88, Grimaldi (1991).

${ }^{40}$ See Cosma \& Whish (2003) at 32.
} 
implementation by EU institutions. These include the general rules and principles on the legal basis for concluding a single case agreement, the law applicable to an agreement, the criteria for legality under EU law as well as the provisions for amendments, termination and problems of performance of a contract. ${ }^{41}$ They further include the definition of matters, which can be addressed by contractual means as opposed to unilateral forms of act. Such instruments are important to ensure actual implementation of EU law by member states and individuals, but inversely, they also offer alternatives to hold administrations accountable by means other than hierarchical control through executive hierarchies. ${ }^{42}$ They are specifically important to regulate the relation between different actors in European system of integrated administration. Especially current political or economic issues demanded cross-departments cooperation, the development of European integrated administration has therefore increased the need for and the use of atypical acts for implementation of EU law.

\section{$\underline{\text { Pre- and Post-Regulation }}$}

For implementation of law, some categorization drawn between the preregulation and the post-regulation function of the act fill the role of atypical act before or after new legal provisions had been created. ${ }^{43}$ The pre-law function can be understood in two different ways. ${ }^{44}$ First, it can be considered to refer to the fact that a particular atypical act is adopted with the objective of elaborating and preparing future EU legislation and policies. Secondly, the pre-law function can also be understood in a more substantive way, in the sense that atypical acts have paved the way for the adoption of legislation in the future.

For pre-law functions, certain categories of atypical acts in spectrum management law can be distinguished. ${ }^{45}$ The major category encompasses preparatory instruments and these instruments are adopted in view of preparing future EU law and policies by providing information on community joint action. ${ }^{46}$ The other one includes the interpretative and decisional instruments aimed at providing guidance for the interpretation and application of the existing EU law. Finally, the last one covers what one could call steering instruments aimed at establishing or giving further effects to objectives and policies or related policy areas. $^{47}$

For spectrum management, atypical acts are used in pre- and post-regulation purposes or for soft guidance. Those flexibilities come at the cost of deficits in democratic legitimacy, legality, and legal certainty. Spectrum management legal preparatory instruments in the pre-law area encompass Green Papers and White Papers, which are used solely by the Commission, and action programs, which

\footnotetext{
${ }^{41}$ See Hofmann (2006).

${ }^{42}$ See Freeman (2000).

${ }^{43}$ Thürer (1990) at 133.

${ }^{44}$ See Ruse-Khan, Jaeger \& Kordic (2010).

${ }^{45}$ Senden (2004) at 10.

${ }^{46}$ See Senden (2004) at 118.

${ }^{47}$ See Senden (2004) at 119.
} 
may be adopted by the Council at a later stage. For the sake of efficiency, action plans refer to a limited number of priority initiatives to be launched at the EU level and include a number of schemes put into action for the purposes of informing people about future steps, the next measures to be taken by the Commission, or the promotion of standardization processes. ${ }^{48}$

They also enable an overall review of the legal system structure in the spectrum management field, identifying gaps within it, especially confirming that the disparities between the national systems having a harmful effect on the proper functioning of the internal market. ${ }^{49}$ Because action programs are quite often established or integrated on the basis of a principle in the TFEU, in the formal binding character of TFEU Art. 288, their adoption is much more formalised than that of Green and White Papers. ${ }^{50}$ Another atypical act which adopts a sort of preregulatory function is the Staff Working Paper. While the Commission uses atypical acts for the above purposes, atypical acts have an influence on future legislation in spectrum management field. This is due to the fact that resolutions consider a number of directives, Green Papers, and Staff Working Papers, among others, calling upon the Commission or member states to initiate new legislative incentives or promote clearer legislative solutions. ${ }^{51}$ The post-regulation function is fulfilled by instruments which are subsequently adapted to existing EU law with a view to implementing legislation or facilitating accurate interpretation and application. ${ }^{52}$ This type of atypical acts is the report from the Commission to the Parliament and to the Council have their source in legal acts themselves or in the resolutions of the Parliament. ${ }^{53}$

\section{Economic Demand and Policy Oriented}

The wave of using atypical acts in sensitive core economic areas such as energy, finances, and telecommunications saw the establishments of EU specialised agencies and dealing certain administrative ruling. Following their establishment, further EU legislation has granted powers to these bodies that had been reserved to the EU institutions proper. ${ }^{54}$ For instance, the European Securities

\footnotetext{
${ }^{48}$ See, e.g., Communication from the Commission to the Council and the European Parliament, Stimulating Technologies for Sustainable Development: An Environmental Technologies Action Plan for the European Union, at 4.1.3. The first action plan for innovation in Europe, Innovation for growth and employment at 5 .

${ }^{49}$ The first action plan for innovation in Europe, Innovation for growth and employment, at 2.4.

${ }^{50}$ See Annex in Dec. 2228/97/EC of the European Parliament and of the Council, of 13 Oct. 1997, establishing a Community action programme in the field of cultural heritage (the Raphael programme).

${ }^{51}$ European Parliament Resolution of 25 Sept. 2008 on collective cross-border management of copyright and related rights for legitimate online music services; European :European Resolution on the impact of new technologies upon the press in Europe; European Parliament resolution on the situation and role of artists in the EU.

${ }^{52}$ See Senden (2004) at 120.

${ }^{53}$ See, e.g., the Report from the Commission to the European Parliament and the Council, Development and implications of patent law in the field of biotechnology an genetic engineering.

${ }^{54}$ Chamon (2011).
} 
and Markets Authority's (ESMA's) power to impose fines under Regulation $648 / 2012$, or its powers that were contested in Short-selling. ${ }^{55}$

In some areas, the strengthening of existing agencies and the establishment of new ones seems to be the EU's favourite response to policy problems or crises such as the proposed establishment of the Single Resolution Mechanism (SRM) or the alteration of the European Railway Agency. ${ }^{56}$ From a legal perspective, some interesting issues have come under the spotlight, showing the problematic nature of the delegation to or conferral of power on these bodies. ${ }^{57}$ One issue relates to the use of TFEU Art.114 as a legal basis to empower EU agencies and the other relates to the limits to empowering these bodies. Although the debate on the limits to empowering agencies has mainly been discussed by academics, these developments have really brought the underlying issues to the political institutions and to the Court. ${ }^{58}$ The EU institutions can be vested with very significant powers, but this only highlights the fact that the framework governing their functioning is underdeveloped. ${ }^{59}$ The proposed inter-institutional agreement could have addressed some problems. In addition, the EU executive should take into account the EU's need to rely on those specialised institutions as well as the atypical acts which the Commission should play in this sphere. ${ }^{60}$

\section{$\underline{\text { Internal and External Relations }}$}

Atypical acts are common in the internal and external trade relationships of the EU. Due to complicated situations regarding EU external trade relations, it may require consensus among the contracting parties which seems increasingly difficult to obtain the agreements. Here, member states and other entities outside of the EU to some extent have moved to atypical acts along the lines of those examined above to pursue their policy goals. ${ }^{61}$ For this practice, the EU has successfully relied on atypical acts for raising enforcement concerns in various fora, providing technical assistance, conducting political dialogues, or preparing guidelines to further the agenda for stronger its enforcement region-wide. These acts have certainly contributed to the conclusion of legally binding obligations in the economic field, and the debate on spectrum management is one of the important subjects in trade negotiations.

\section{Some Arguments Regarding the Use of Atypical Acts}

The use of atypical acts may contribute significantly to the legislative and policy process for steering and flexible, and may yield additional beneficial effects

\footnotetext{
${ }^{55}$ See Regulation 648/2012 on OTC derivatives, central counterparties and trade repositories, and Case C-270/12 United Kingdom v Parliament and Council (Short-selling) (2014).

${ }^{56}$ See EU COM (2013)27 final; COM (2013)30 final and COM (2013)31Final.

${ }^{57}$ Chamon (2014a).

${ }^{58}$ Hofmann \& Morini (2012) and see also Griller \&. Orator (2010).

${ }^{59}$ Geradin (2004) at 9.

${ }^{60}$ See Chamon (2014a).

${ }^{61}$ See Ruse-Khan, Jaeger \& Kordic (2010).
} 
like enhancement of information and transparency. ${ }^{62}$ In turn, atypical acts may also associate with some drawbacks in terms of democratic legitimacy, legality, and legal certainty. ${ }^{63}$

\section{Administrative Control}

With the benefits of flexible and steering, the legislators have frequently used the atypical acts for the political and economic purposes and one of the convenient methods to strengthen the administrative control were through the creation of specialised agencies. It should be noted that the EU legislator not only increasingly relies on EU agencies, but also increasingly instructs member states to create independent agencies in their national legal orders. ${ }^{64}$ Meanwhile, the powers of the European legislators including Parliament, Commission and Council vis-à-vis EU agencies could be strengthened. ${ }^{65}$ It may be noted that during the Convention on the Future of Europe, the Parliament proposed to allow EU agencies to adopt implementing acts, with a scrutiny mechanism allowing the arms of the legislature and the Commission to repeal such acts. ${ }^{66}$

Some scholar suggested giving the Commission veto rights over agencies' decisions. ${ }^{67}$ Whether this would be workable is another question, as the information asymmetry between the Commission and agencies would probably relegate a veto option to a mere theoretical possibility. ${ }^{68}$ Enhancing the Commission's position through its representation on the agencies' boards is another possibility ${ }^{69}$ During the wave of agency creation, the Commission had indeed proposed to establish agencies' boards with parity between Council and Commission representatives, which the Commission had proposed this in its draft inter-institutional agreement. ${ }^{70}$ Some scholar had challenged that if the EU legislature adopts a number of harmonization measures in different instruments based on TFEU Art.114 and then complements this body of legislation with an act solely establishing an EU agency would be more effective than the other instruments. $^{71}$

With the use of TFEU Art.114 as a legal basis for agency creation was sanctioned by the Court in the ENISA case. ${ }^{72}$ In that case, the Court had to deal with two issues raised by the United Kingdom: whether the EU Agency for Network and Information Security's (ENISA) tasks could be qualified as

\footnotetext{
${ }^{62}$ Ruse-Khan, Jaeger \& Kordic (2010).

${ }^{63}$ See Ruse-Khan, Jaeger \& Kordic (2010).

${ }^{64}$ Ludwigs (2011) at 44-46.

${ }^{65}$ Griller \& Orator (2010) at 29.

${ }^{66}$ See Resolution 17, the European Parliament on the typology of acts and the hierarchy of legislation in the European Union [2002] OJ C31E/126.

${ }^{67}$ See Griller \& Orator (2010) at 29.

${ }^{68}$ See Chamon (2010).

${ }^{69}$ See Chamon (2010).

${ }^{70}$ See EU Commission, "Interinstitutional Agreement on the operating framework for the European regulatory agencies".

${ }^{71}$ See Chamon (2010).

${ }^{72}$ See ENISA (C-217/04) 44.
} 
"approximation measures;" and whether organizational arrangements, such as setting up a body, are possible under TFEU Art.114. However, ENISA is an atypical agency in that it is only established for a limited period, even if the institutions keep amending its founding regulation, extending that period every time. $^{73}$ The distinction on democratic grounds for using of atypical acts is not of a fundamental nature. One could take the Parliament's democratic scrutiny powers compared the Commission and mirror them in the acts laying down the statutes of EU institutions. EU institutions would find themselves in the same position as the Commission, except for the fact that the Parliament's scrutiny powers over the institutions would only be laid down in secondary law.

In addition, the contents of atypical acts may consist not only of the codification and explanation of the different sources of EU law, but may also include the Commission's own interpretation for EU law, which is not authoritative. Therefore, it is not always easy to distinguish between those aspects of different sources merely from the codification of the Court or the explanation of the Commission's interpretation. Since the atypical act is based on secondary legislation, it is likely to be an accurate reflection of the obligations of member states under the EU law and could be argued that the interpretation of Commission may not be regarded as authoritative. One way to reconcile the need for administrative interpretation with the need to ensure that the type of atypical acts does not alter the obligations of the member states under the EU law is to allow for judicial review over the content of such instruments.

For the scope of limitation in diverging interpretations at national level, the interpretation by the Commission is conducive to uniformity for the EU. Since the Commission has the supervisory responsibilities in spectrum management of EU, it should be aware of the difficulties linked with the implementation of EU law and the demands of the expertise for presentation the communications in a manner suitable for national administrations. Hence it should be concluded that administrative interpretation may be the most efficient means of ensuring greater transparency and information to uniformity for the EU. Obviously, as the aim of administrative aim is to interpret EU law they tend to fulfil a function that is reserved by the Treaty for the Court. It is important, therefore, that the Court be given opportunities to review the interpretation proposed by the Commission. It is not only the jurisdiction of the Court that is challenged, however, but also that of the member states.

One of the main areas of the proliferation of atypical acts was referred to above as being the network structures of EU administrative proceedings. Given the possibility of institutions to enter into force of EU laws, the question arises as to the relation between negotiated agreements between institutions and other parties and unilateral acts of institution's own. Although atypical acts were often used for implementation of certain legal practice, negotiated agreements were often concluded to allow for the implementation of a Commission decision. In this

${ }^{73} \operatorname{Vos}(2000)$ at 1122. 
respect, in the reality of EU administrative laws and proceedings, complex relations between Commission decisions and agreements arise. ${ }^{74}$

The non-conclusive typology of acts in EC Art.249 and acts according to Art. 12-15 and 34 does not contain references to agreements or acts. Also, the typology established by Constitutional Treaty Arts I-33 to I-38 does not contain any reference to the possibility of agreements for normative or single case use. However, Art.I-33(2) contains a sort of hidden opening clause for atypical acts by stating that the European Parliament and Council "when considering proposals for legislative acts" "shall refrain from adopting acts not provided for by this Article in the area in question." ${ }^{, 75}$ There is no such clause existing with respect to nonlegislative acts. This may lead to the conclusion that the restraint called for with respect to atypical acts for legislation is not required in implementing acts. ${ }^{76}$ Within these legal structures of networks in practice, administrative proceedings are established as composite proceedings.

\section{Legislative Remedies}

Following years of practice at atypical acts, a framework governing the use of atypical acts has still not been established in primary law. For a long time, the legal requirements of establishing agencies has been discussed and consented was that agency creation required recourse to TFEU Art.352 as a legal basis. ${ }^{77}$ The Court also confirmed the primary law, since the entry into force of the Lisbon Treaty, explicitly provides for legal remedies against the acts of EU institutions. It found that the power foreseen in the contested TFEU Art.28 does not correspond to any of the situations defined in TFEU Art. 290 and 291. As a result, the EU legislator, by inscribing Art.28 in Regulation 236/2012, did not undermine the system as set up under TFEU Art. 290 and 291.

In the EU legal order, the infringements the principles of legality and legal certainty in particular which may potentially ensue from atypical acts of the institutions are not acceptable. Consequently, general remedies must be found to forestall such infringements and enhance the positive effects of atypical acts. It suggests including in the Treaty a rule whereby the legislator should abstain from adopting non-standard acts on a subject when legislative proposals or initiatives on the same subject have been submitted to it. The use of non-standard acts in legislative areas may give the erroneous impression that the EU legislates through the adoption of non-standard instruments.

For the Treaty of Lisbon, these proposals were not implemented. Nonetheless, that Treaty shows a limited tendency to reduce the proliferation of atypical acts by aligning a few of them with standard instruments. ${ }^{78}$ By contrast, the remedies discussed in literature aim at the establishment of some forms of administrative

\footnotetext{
${ }^{74}$ Joined Cases T 369/84 \& 85/95, DIR International Film (1998); Case C-48/96 P, Windpark Groothusen (1998) and Case 56/77, Agence europeenne (1978).

${ }^{75}$ Hofmann (2003).

${ }^{76}$ See Hofmann (2003).

${ }^{77}$ Lauwaars (1979) at 376.

${ }^{78}$ See Lenaerts \& Van Nuffel (2005).
} 
rule making. ${ }^{79}$ The simplest suggestion in this regard extends to the amendment of TFEU Art. 288 to include at least the most commonly used instruments, the applicable procedures, and their legal effects. ${ }^{80}$ Likewise, it may be sufficient to distinguish clearly between the procedural and substantive aspects of atypical acts and to elaborate the procedural rules while continuing to allow for flexibility in terms of the differentiated application of substance. ${ }^{81}$

The other suggestion is to focus more on the link between procedural rules and legal quality of atypical acts with the delegation of a power for the Commission to issue formal implementing rules, which would be similar to block exemption regulations, and could potentially be coupled with control and participation mechanisms. ${ }^{82}$ It is argued that such formalization would also facilitate judicial control over such acts because such proposals significantly limit the procedural flexibility afforded for the adoption of atypical acts. ${ }^{83}$ In particular, formal implementing rules comparable to block exemption regulations would necessarily be generally applicable law, thus removing the possibility of pursuing steering effects and enforcement or testing policy changes. ${ }^{84}$ It may not seem beneficial to do away with those information and consultation documents in favour of a limited number of binding implementing rules. This solution therefore clearly goes too far in limiting the use of atypical acts.

The practice has shown that procedural flexibility in the adoption of atypical acts may decrease the number of institutional players involved in decision making and increase the hurdles in the way of interested parties getting involved in the decision making process. ${ }^{85}$ The wide variety of atypical acts and the range of policy areas concerned may render flawed an approach which sought to adopt onesize-fits-all approaches, thus imposing the same rules for all types of instruments over all policy areas. ${ }^{86}$ The assessment or balancing of positive versus negative effects associated with the use of soft atypical acts is therefore likely to differ for each type of act and the various policy areas. ${ }^{87}$ The probable need for a differentiated approach for atypical acts should not detract from the need to lay down a relevant set on the next occasion for European integration.

\section{Judicial Review}

Due to political and economic changes, EU institutions have to frequently use the atypical act to adjust themselves for both internal and external markets as well as speed up the policy process. Using such non-standard and non-binding acts under TFEU, the European Courts had to face and explicitly begin to address the questions of the nature of delegations and the positions of EU institutions in

\footnotetext{
${ }^{79}$ See Rudloff \& Simons (2006) at 178.

${ }^{80}$ See Bieber and Salomé (1996) at 924.

${ }^{81}$ See Cini (2000) at 24.

${ }^{82}$ See Rudloff \& Simons (2006) at 171 and 178.

${ }^{83}$ See Rudloff \& Simons (2006) at 175.

${ }^{84}$ See Ruse-Khan, Jaeger \& Kordic (2010).

${ }^{85}$ Christiansen \& Polak (2009); Peters (2004).

${ }^{86}$ See Ruse-Khan, Jaeger \& Kordic (2010).

${ }^{87}$ See Cini (2000) at 25.
} 
implementing EU policies in the absence of a clear constitutional mandate. ${ }^{88}$ It is the Court's obligation to review and interpret the meanings as well as effects of those acts while disagreement or disputes rising under circumstances.

TFEUArt.263 states that "The Court of Justice of the European Union shall review the legality of legislative acts, of acts of the Council, of the Commission and of the European Central Bank, other than recommendations and opinions, and of acts of the European Parliament and of the European Council intended to produce legal effects vis-à-vis third parties. It shall also review the legality of acts of bodies, offices or agencies of the Union intended to produce legal effects vis-àvis third parties" ${ }^{\prime 9}$ In the case of France v. Commission (1993), the Court states that "the principle of legal certainty, which is part of the Community legal order, requires Community legislation to be clear and its application to be foreseeable for all interested parties. As a result of that requirement, any act intended to have legal effects must derive its binding force from a provision of Community law which prescribes the legal form to be taken by that act and which must be expressly indicated therein as its legal basis, failing which the act in question will be null and void." 90

The Court has interpreted this formula as meaning that an action for annulment is possible "against any measures adopted by the institutions, whatever their nature or form, which are intended to have legal effects." ${ }^{91}$ In the Shortselling case, the Court had noted that a legislative act adopted on that legal basis must comprise measures for the approximation of the provisions laid down by law, regulation or administrative action in the member states and have as its object the establishment and functioning of the internal market. ${ }^{92}$ The problem is that such judicial review is not possible when the Commission remains within the realm of interpretation. In other words, as long as the Commission's interpretation of EU law does not impose further obligations on the member states, there is no possibility for the Court to review the compatibility of this interpretation with its own case law on the subject through a direct action for annulment. Although the Court seemed to have a conceptual difficulty with the idea of assessing the validity of non-binding acts, it did so nevertheless by comparing the directions for interpretation included in the notice with its own appraisal of EU law.

The Court has delivered an important ruling, sanctioning future use of atypical acts but without, however, setting limits to the further development of this process. The Court found TFEU Art.114 to be a suitable legal basis to empower the legality of a number of other institutions. Using TFEU Art.352 rather than TFEU Art.114 would have put a serious brake on future creation of specialised agencies and use of atypical acts, since every member state would have gained a veto power and it would have been doubtful whether TFEU Art.114 could have been used. In other words, the Court had rejected the use of TFEU Art.114 to

\footnotetext{
${ }^{88}$ Hofmann \& Morini (2012).

${ }^{89}$ TFEU Art. 263 (ex Art. 230 TEC).

${ }^{90}$ See Case C-325/91, France v. Commission (1993).

${ }^{91}$ Case 22/70, Commission v. Council, (European Agreement on Road Transport) (1971).

${ }^{92}$ See Case C-270/12, United Kingdom v Parliament and Council (Short-selling) (2014) 100.
} 
establish a new legal form for a cooperative society that would exist alongside the existing national legal forms and found there was no "approximation.""93

In certain cases, the Court scrutinises acts adopted by the institutions on the merits of their substance, not their form or denomination. ${ }^{94}$ The test here is whether the decision maker actually intended the instrument to have legal effects, even if its form prima facie indicates a non-binding nature. ${ }^{95}$ Where an act of whatever form or denomination is assessed as essentially constituting a decision or regulation in the meaning of TFEU Art. 288, that act is to be judged by the same standards. ${ }^{96}$ For such quasi-decisional, binding acts, the Court therefore exercises strict control of legality in the sense that they must not infringe or alter the rules established by the Treaty. ${ }^{97}$

In theory, the monopoly of the Court over the interpretation of EU law seems fairly well-protected against the risk of encroachment on the part of the Commission. However, in order to review the interpretation of the Commission, the Court depends on other actors, particularly the member states themselves, to initiate procedures. Although the legislative process of setting up and empowering institutions would have partly diminished the role of the European Parliament, the Court's ruling had supported on this point, even if the EU's legitimacy would benefit from reducing the emphasis on the legislator's large discretion and emphasizing, instead, the legislator's duty to elaborate on why powers should, exceptionally, be vested in certain institutions. ${ }^{98}$ Adding to these uncertainties is the fact that the Courts are not bound by the interpretation of norms suggested by the Commission in a steering document, ${ }^{99}$ so that individuals cannot be fully certain to act in conformity with the law even when complying with such an instrument. $^{100}$

With the concern of allowing the EU to fulfil its objectives and the involvement of EU institutions, the Court's ruling appears much more like a simplification exercise. The Court has sanctioned the use of atypical acts, since the institutions have resorted to such acts already for a certain period, but that the Court has ruled that it is perfectly possible for atypical EU bodies, rather than the institutions, to adopt equally atypical acts. ${ }^{101}$

\footnotetext{
${ }^{93}$ See Case C-436/03, European Cooperative Society [2006] E.C.R. I-3733, 44.

${ }^{94}$ See Case 60/81, IBM v. Commission (1981); Joined Cases T-125 and 127/97, Coca-Cola Co and Coca Cola Enterprises Inc. v. Commission (2000).

${ }^{95}$ See Case C-57/95, Commission v. France (1997); Case C-325/91, France v. Commission (1993).

${ }^{96}$ See Case C-57/95, Commission v. France (1997). See also Case C-325/91, France v. Commission (1993).

${ }^{97}$ See Ruse-Khan, Jaeger \& Kordic (2010).

${ }^{98}$ Vos (2003).

${ }^{99}$ See Case C-313/90, CIRFS v. Commission (1993); Case C-311/94, IJssel-Vliet Combinatie BV v. Minister van Economische Zaken (1996); Case C-382/99, Netherlands v. Commission (2002).

${ }^{100}$ See Cosma and Whish (2003) at 34.

${ }^{101}$ See Chamon (2014) at 159.
} 


\section{Publication and Lack of Transparency}

The EU legislation has stipulated a comprehensive principle of transparency for many institutions, not least with the aim of promoting the public involvement in the legislative process to promote better governance and ensure the public participation, - EU institutions, bodies, and offices thus should conduct their work as openly as possible. ${ }^{102}$ However, the negotiations of law making process in the EU had long time suffering from lack of transparency, the scope of the negotiations and draft documents are typically not publicly accessible. Interested parties cannot voice their concerns during negotiations, but are confronted with the negotiation outcome. ${ }^{103}$

Since atypical acts are not subject to mandatory publication in the Official Journal, it may become more difficult for potential addressees to become aware of policy changes affecting them. Because atypical acts are not binding on individual parties, parties affected merely by the steering effect resulting from such acts cannot attack them before the Courts. Due to its difficult to access, ambiguous in language, of unclear normative status, certain atypical acts may result in a decrease in intra-institutional as well as third-party transparency. The wide variety of atypical acts used in practice thus has been criticised for its systemic complexity and unclear status, entailing a lack of legislative and administrative transparency vis-à-vis third parties. ${ }^{104}$ Because remedies towards a better balancing of the positive and negative effects, the recourse to atypical acts can be envisaged on the basis of the existing framework of primary law for confidentiality and access to documents. It was shown that some atypical acts, like Green Papers, pursue precisely the effect of involving a broad range of interested parties in the decision making process via public consultations, so that the negative effects on transparency cannot be deemed to exist generally in relation to those atypical acts. ${ }^{105}$

For the area of spectrum management, recourse to atypical acts in the prenegotiation and negotiation processes should incorporate minimum standards of third-party transparency and public consultation and establish clear rules for negotiation stages which are to be publicised as compared to information that is to be kept secret. This means that whatever a given instrument is formally designated as, the examination of its substance may lead to the conclusion that it essentially constitutes a decision or regulation in the meaning of TFEU Art. $288 .{ }^{106}$

Clearly, the function of public information and enhancement of transparency is particularly important in practice for private individuals seeking to anticipate policies and actions. ${ }^{107}$ With impacts on the behaviour in economic and normative compliance terms, the public information function presented by an institution to third parties may also be seen from the point of view of its steering aspect. The

\footnotetext{
${ }^{102}$ TFEU Art.15(1).

${ }^{103}$ See Ruse-Khan, Jaeger \& Kordic (2010).

${ }^{104}$ See Cosma \& Whish (2003) at 25.

${ }^{105}$ See Ruse-Khan, Jaeger \& Kordic (2010).

${ }^{106}$ Ruse-Khan, Jaeger \& Kordic (2010).

${ }^{107}$ See Case C-310/99, Italy v. Commission (2002); Case C-387/97, Commission v. Greece (2000).
} 
recourse to atypical acts has accordingly and rightly been described as a form of regulation by information or publication. ${ }^{108}$ Atypical acts may contribute significantly to the legislative and policy process in terms of soft steering and may yield additional beneficial effects like the enhancement of information and transparency.

\section{Internal Members and Third Party Effects}

The European Court has recognised two aspects of indirect steering effects of atypical acts which carry legal significance for third parties in terms of the creation of enforceable obligations. ${ }^{109}$ First, the Court obliges national courts to take nonbinding instruments into account to comply with their obligation to interpret national law in conformity with EU law or where those instruments are designed to supplement binding EU law provisions. ${ }^{110}$ Second, the EU legal order protects the legitimate expectations of parties that the institution deliberately issuing information on its policy or position in a given context will adhere to that policy line. ${ }^{111}$ In other words, even atypical acts incapable of formally binding third parties bear a certain self-binding effect on the issuing authority. If the self-binding character is not respected, any discrepancies between the policy announcement in the atypical act and a subsequent binding individual decision can be attacked in the course of an action for annulment of that later decision. ${ }^{112}$

Although the type of atypical acts may not be binding on the member states, it may encroach upon the member states' areas of competence. Because atypical acts are a useful source for administrative means, such acts are likely to influence the application of the EU law by the national administrations. Consequently, it appears that there should be some form of control by the member states over such instruments. The substantial flexibility afforded by atypical acts in terms of differentiation of their legal effects may also give rise to uncertainties in the determination of the addressees and even of legal effects on a scale ranging from no binding effect to self-binding effects to full third-party binding effect.

The less formal and legal character of these acts often allows them to be more policy-driven, and so makes it easier to address key political concerns relevant for EU in a more flexible and current manner. On the EU's response to the Euro crisis, this style of function is at a time when the coherence of the EU legal order under pressures. ${ }^{13}$ For example, some acts have tended to focus strongly on the enforcement of spectrum management in particular. Apart from entering into binding agreements among member states which include specific additional obligations to enforce the regulations of spectrum management, the EU uses various flexible tools which can be considered as atypical acts within EU.

\footnotetext{
${ }^{108}$ See Rudloff \& Simons (2006) at 153, 164, and 169.

${ }^{109}$ See Ruse-Khan, Jaeger \& Kordic (2010).

${ }^{110}$ See Case C-322/88, Salvatore Grimaldi v. Fonds des Maladies Professionnelles (1991); Case C207/01, Altair Chimica SpA v. ENEL Distribuzione SpA (2003)..

${ }^{111}$ See Case C-313/90, CIRFS v. Commission (1993); Case C-409/00, Spain v. Commission (2003); Case C-91/01, Italy v. Commission.

${ }^{112}$ See Case C-443/97, Spain v. Commission (2000).

${ }^{113}$ Dawson \& de Witte (2013) at 818.
} 
It is not surprising that the EU is pursuing a policy agenda which demands effective operation, and especially the policy enforcement for spectrum management. For the types of atypical acts, one is for systematically raising enforcement concerns of spectrum management in multilateral, regional, and bilateral contexts. The EU plans to monitor the compliance of national enforcement legislation, in particular in the priority countries. Bilaterally and regionally, the emphasis is placed on extending and clarifying enforcement provisions in agreements. The other is for technical assistance, realizing that improving the enforcement involves not primarily drafting legislation but training professionals, police forces, and customs officials and setting up relevant task forces and agencies. The EU wants to focus its technical assistance accordingly and the enforcement assistance will focus on identified priority countries or move away from being merely demand driven to integrate specific EU concerns.

In addition, the atypical acts are designed for political dialogue, institutional cooperation, raising public awareness, and creating public-private partnerships. The EU strategy includes several other elements such as a political dialogue should strongly convey the message that the EU is willing to assist member states in raising the level of enforcement, but also that it will not refrain from using the instruments at its disposal in cases where deficient enforcement is harming its right-holders. ${ }^{114}$

For external relationship, the EU's strategy comprises a comprehensive action plan to facilitate the enforcement of spectrum management in third countries from technical assistance and utilizing multilateral, regional, and bilateral fora for bringing dispute settlement cases and related sanctions. It involves mainly soft law mechanisms such as surveying and monitoring the enforcement in third countries, initiatives for negotiating stronger enforcement provisions, providing tailored technical assistance, conducting political dialogues, or preparing guidelines. ${ }^{115}$ Most of these actions or acts are of a merely political nature with no direct legal effect. In this regard, they are flexible tools for responses of the EU's objective of spectrum management.

\section{Conclusion}

For policy demands and economic integrations, the EU legal system have developed into an evolutionary fashion and one of these evolutionary developments is an increase in the use of atypical acts. These are forms of act which are non-standard legislative instruments and non-listed legal acts under TFEU Art. 288 to 292. For steering legislation purpose and implementing the policy and law, EU institutions increasingly choose this type of non-standard instruments to obtain greater flexibility. In particular, the uses of atypical acts are common in the sensitive core economic areas such as telecommunications sector and proved by the establishments of EU specialised agencies to deal with certain

\footnotetext{
${ }^{114}$ European Commission - DG Trade, Strategy for the Enforcement of Intellectual Property Rights in Third Countries (2005).

${ }^{115}$ See Ruse-Khan, Jaeger \& Kordic (2010).
} 
administrative ruling. However, the use of atypical acts may also associate with some drawbacks including lack of transparency, shortage of legal certainty and legitimacy, etc.

For examples, the Commission has used atypical acts as legal steering instruments to provide legal instructions to firms, national authorities, or courts for the purpose of spectrum management. Such instruments are adopted in areas for which the Commission has discretionary power in order to provide the guidance to operators as to the way the Commission intends to use its discretion in the areas of information technology and spectrum management. The less formal and legal character of these acts often allows them to be more policy-driven and makes it easier to address key political concerns in a more flexible and current manner especially the high-speed changing information technology. Therefore, atypical acts are an excellent instrument for institutions to prepare the launch of new policies and test their impacts. While atypical acts are most commonly associated with internal EU legislation under TFEU Art. 288, the article then tried to examine atypical acts of the EU concerning spectrum management in the EU's legal order and its development.

Since the Commission has the supervisory responsibilities in spectrum management, the administrative interpretation may be the most efficient means of ensuring greater transparency and publication for the EU itself and member states. However, the Commission's own interpretation for EU law may not be authoritative. Thus, there are some proposals for remedies in literature aimed at the establishment of some forms of administrative rule making. One suggestion is making the amendment of TFEU Art. 288 to include at least the most commonly used instruments, procedures, and effects; the other suggestion is to focus on the link between procedural rules and legal quality of atypical acts to block exemption regulations. However, the wide variety of atypical acts and the range of policy areas concerned may lower the possibility for seeking to adopt one-size-fits-all approaches or imposing the same rules for all types of instruments over all policy areas.

In the other way, due to the Court's obligation to review and interpret the meanings as well as effects of atypical acts, the European Court may be given the opportunities to review the interpretation proposed by the Commission. Reviewing such non-standard and non-binding acts under TFEU, the Courts had to face and address the questions of the nature of delegations and the positions of EU institutions in implementing EU policies in the absence of a clear Treaties definition. The other issue is that such judicial review is not possible when the Commission remains within the realm of interpretation or without imposing further obligations on the member states. Thus the Court's review may be limited to case-by-case basis but not on general applicable rules. Additionally, because atypical acts are not binding on individual parties, parties affected merely by the steering effect resulting from such acts cannot attack them before the Courts. The wide variety of atypical acts used in practice thus has been criticied for its systemic complexity and unclear status.

For the area of spectrum management, the function of public information and enhancement of transparency is particularly important in practice. Because the 
spectrum is one of the natural resources shared by the whole community, the use of atypical acts may contribute significantly to the legislative and policy process in terms of soft steering and for private individuals seeking to anticipate policies and actions. On the other hand, since the spectrum resource covers areas of military, aviation, maritime, business, and emergency uses, recourse to atypical acts should keep minimum standards of third-party transparency and public consultation and establish clear rules for negotiation stages in the pre-negotiation and negotiation processes.

Atypical acts are also common in the internal and external trade relationships of the EU. For EU internal members, although the type of atypical acts may not be binding on the member states, it may encroach upon the member states' areas of competence. Because atypical acts are a useful source for administrative means, such acts are likely to influence the application of the EU law by the national administrations. Under this article, the comparative analysis shows that whereas atypical acts in the internal context are generally used to enhance decision making transparency and the public involvement and to achieve better enforcement or post-regulatory guidance, virtually few of those effects can be associated with atypical acts. For external relationship, due to its complicated situations between the EU and its major trade partners, it may require consensus among the contracting parties which seems increasingly difficult to achieve the agreement. Therefore, how to upgrading effective operations in spectrum management and balancing the drawbacks and benefits of the use of atypical acts would be a challenging task for the EU itself and member states.

\section{References}

Bieber, A. \& I. Salomé (1996). 'Hierarchy or Norms in European Law' in C.M.L.Rev 33:907-930.

Cairns, W. (2002). Introduction to European Union Law. 2nd ed.

Chamon, M. (2010). 'EU Agencies: Does the Meroni Doctrine Make Sense?' in Maastricht J. Eur. Comp. Law 17(3):281-305.

Chamon, M. (2011). 'EU Agencies between 'Meroni' and 'Romano' or the Devil and the Deep Blue Sea' in C.M.L. Rev. 48:1055-1056.

Chamon, M. (2014). 'Le recours à la soft law comme moyen d'éluder les obstacles constitutionnels au développement des agences de l'UE' in RUE 576:152-160.

Chamon. M. (2014a). 'The empowerment of agencies under the Meroni doctrine and article 114 TFEU: comment on United Kingdom v Parliament and Council (Shortselling) and the proposed Single Resolution Mechanism' in E.L. Rev. 39(3):380-403.

Christiansen, T. \& J.J.C. Polak (2009). 'Comitology between Political Decision-Making and Technocratic Governance: Regulating GMOs in the European Union' in Eipascope 1:5-11.

Cini, M. (2000).'From Soft Law to Hard Law? Discretion and Rulemaking in the Commission's State Aid Regime' in European University Institute Working Paper 35:4-19.

Cosma, H.A. \& R. Whish (2003). 'Soft Law in the Field of Competition Policy' in European Bus. L. Rev. 14(1): 25-26. 
Dawson, M. \& F. de Witte (2013). 'Constitutional Balance in the EU after the Euro-Crisis' in Modern L. Rev. 76(5):817-644.

Freeman, J. (2000). 'The Private Role in Public Governance' in N.Y.U. Law Rev. 75:543675.

Geradin , D. (2004). 'The Development of European Regulatory Agencies: What the EU should Learn from the American Experience' in C.J.E.U.L. 11:1-52.

Griller, S. \& A. Orator (2010). 'Everything under Control?' in Eur.L. Rev. 35(1):3-35.

Hofmann, H.C.H. (2003). 'A Critical Analysis of the New Typology of Acts in the Draft Treaty Establishing a Constitution for Europe' in European Integration Online Papers (EIOP) 7:1-46.

Hofmann, H.C.H. (2006). 'Agreements in EU law' Eur.L. Rev. 31(6):800-820.

Hofmann, H.C.H. \& A. Morini (2012). 'Constitutional Aspects of the Pluralisation of the EU Executive through Agencification in Eur.L. Rev. 36:419-443.

Hofmann, H.C.H. \& A.H. Türk (2006). 'Explaining Implementation - the Internal and The external point of view; in H.C.H. Hofmann \& A. Türk (eds.) (2006) EU Administrative Governance. London: Edward Elgar Publishing, at 74-89.

Rudloff B. \& J. Simons (2006). European Governance of Food Safety; in H.C.H. Hofmann \& A. Türk (eds.) (2006) EU Administrative Governance. London: Edward Elgar Publishing, at 146-184.

Klabbers, J. (1994). 'Informal Instruments before the European Court of Justice' in 31 C.M.L.Rev. 31(5):997-1023.

Klabbers, J. (1998). 'The Undesirability of Soft Law' in 67 Nordic J. Int'l L. 67:381-391.

Lauwaars, R.H. (1979). 'Auxiliary Organs and Agencies in the E.E.C' in C.M.L.Rev. 16:365-387.

Lefevre, S. (2004). 'Interpretative Communications and the Implementation of Community Law at National Level' in E.L. Rev. 29(6):808-822.

Lenaerts, K. \& P. Van Nuffel (2005). Constitutional Law of the European Union. 2nd ed. London: Sweet \& Maxwell.

Ludwigs, M. (2011). 'Die Bundesnetzagentur auf dem Weg zur Independent Agency?' Europarechtliche Anstöße und verfassungsrechtliche Grenzen' in Die Verwaltung 44:41-74.

Meesen. K. M. (1997).'Administrative Guidelines and Judicial Control: Comments on the Law and Practice of Germany and the European Union' in Administrative discretion and problems of accountability: proceedings, 25th Colloquy on European Law, Oxford (United Kingdom), 27-29 September 1995 at 103.

Melchior, M. (1979). 'Les communications de la commission, contribution à l'étude des actes communautaires non prévus par les traits' in M.F. Dehousse (1979) La Construction européenne, Vol.2. Paris: Nathan; Brussels: Labor at pp. 243-258.

Peters, A. (2004). 'European Democracy After the 2003 Convention' in CMLRev 41:3785.

Petit, N. \& M. Rato (2008). 'From Hard to Soft Enforcement of EU Competition Law - A Bestiary of "Sunshine" Enforcement Instruments' in Alternative Enforcement Techniques in EC Competition Law, pp. 183-220.

Ruse-Khan, H.G., Jaeger, T. \& R. Kordic (2010). 'The Role of Atypical Acts in EU External Trade and Intellectual Property Policy' in European Journal of International Law 21(4):901-939.

Senden, L. (2004). Soft Law in European Community Law. Portland: Hart Publishing.

Snyder, F. (1994). 'Soft Law and The Institutional Practice in The European Community' in (ed.) S. Martin (1994) The Construction of Europe, Essays in Honour of Emile Noël. Netherlands: Springer, at 197-225. 
Thurer, D. (1990) "The Role of Soft Law in the Actual Process of European Integration," in O. Jacot-Guillarmod \& P. Pescatore (eds.) L'avenir du libre-échange en Europe: vers un espace économique européen? Zurich: Schultess Polygraphischen Verlag, at 132-133.

Vos. E. (2000). 'Reforming the European Commission: What Role to play for EU Agencies?' in C.M.L Rev. 37:1113-1134.

Vos, E. (2003). 'Agencies and the European Union' in T. Zwart and L. Verhey (eds), Agencies in European and Comparative Perspective, Antwerpen: Intersentia, at 128129.

Weiler. J.H.H. (2010). 'Dispatch from the Euro Titanic: and the Orchestra Played on' in E.J.I.L. 21(4):805-813.

\section{European Court Reports}

Case 22/70, Commission of the European Communities v. Council of the European Communities (1971) ECR 263.

Case 59/75, Pubblico Ministero v. Flavia Manghera and others (1976) ECR 91.

Case 56/77, Agence europeenne (1978) ECR 2215,

Case 60/81, IBM v. Commission (1981) ECR 2639.

Case 294/83, Parti écologiste 'Les Verts' v. European Parliament (1986) ECR 1339.

Case C-322/88, Salvatore Grimaldi v. Fonds des Maladies Professionnelles (1991) ECR 4407.

Case C-313/90, Comité International de la Rayonne et des Fibres Synthétiques and others (CIRFS) v. Commission of the European Communities (1993) ECR I-1125.

Case C-325/91, France v. Commission (1993) ECR I-3283.

Case C-311/94, IJssel-Vliet Combinatie BV v. Minister van Economische Zaken (1996) ECR I-5023.

Case C-57/95, Commission v. France (1997) ECR I-1627.

Case C-48/96, P, Windpark Groothusen (1998) EC. I-2873.

Case C-387/97, Commission v. Greece (2000) ECR I-5047.

Case C-443/97, Spain v. Commission (2000) ECR I-2415.

Case C-310/99, Italy v. Commission (2002) ECR I-2289.

Case C-382/99, Netherlands v. Commission (2002) ECR I-5163

Case C-409/00, Spain v. Commission (2003) ECR I-1487

Case C-91/01, Italy v. Commission (2004) ECR I-4355.

Case C-207/01, Altair Chimica SpA v. ENEL Distribuzione SpA (2003) ECR I-8875.

Case C-436/03, European Cooperative Society [2006] ECR I-3733, 44.

Case C-270/12, United Kingdom v Parliament and Council (Short-selling) January 22, 2014

Cases T 369/84 \& 85/95, DIR International Film (1998) ECR II-357, 55

Cases T-125 \& 127/97, Coca-Cola Co and Coca Cola Enterprises Inc. v. Commission (2000) ECR II-1733.

\section{Legal Instruments}

Annex in Dec. 2228/97/EC of the European Parliament and of the Council, of 13 Oct. 1997, establishing a Community action programme in the field of cultural heritage (the Raphael programme), OJ (1997) L 305/31.

Commission Notice on Cooperation between the Commission and the Courts of the EU Member States in the application of Articles 81 and 82 EC, OJ (2004) C 101/54. 
Commission Notice on Cooperation within the Network of Competition Authorities, OJ (2004) C 101/43.

Commission Notice on immunity from fines and reduction of fines in cartel cases, OJ (2002) C 45/3.

Commission Notice on Informal Guidance relating to Novel Questions concerning Articles 81 and 82 of the EU Treaty that arise in Individual Cases (Guidance Letters), OJ (2004) C 101/78.

Commission Notice on the Handling of Complaints by the Commission under Articles 81 and 82 of the EU Treaty, OJ (2004) C 101/65.

Commission staff Working Document, Impact assessment reforming cross-border collective management of copyright and related rights for legitimate online music services, SEC(2005)1254, 11 Oct. 2005.

Commission Staff Working Document, Media pluralism in the Member States of the European Union, SEC (2007)32, 16 Jan. 2007.

Commission Staff Working Paper accompanying the White Paper on damages actions for breach of the EU antitrust rules SEC (2008)404 Final.

Communication from the Commission to the Council and the European Parliament, Stimulating Technologies for Sustainable Development: An Environmental Technologies Action Plan for the European Union, $\operatorname{COM}(2004) 38$, at 4.1.3. The first action plan for innovation in Europe, Innovation for growth and employment, $\operatorname{COM}(96) 589$, at 5.

DG Competition discussion paper on the application of Article 82 of the Treaty to exclusionary abuses, Dec. 2005.

EU COM (2013)27 final, COM (2013)30 final and COM (2013)31Final.

EU Commission "Draft Interinstitutional Agreement on the operating framework for the European regulatory agencies" COM (2005) 59 final, 7.

European Commission - DG Trade, Strategy for the Enforcement of Intellectual Property Rights in Third Countries (12 Apr. 2005).

European Parliament Resolution of 25 Sept. 2008 on collective cross-border management of copyright and related rights for legitimate online music services, OJ (2010) C $8 \mathrm{E} / 105$.

European Parliament Resolution on the impact of new technologies upon the press in Europe OJ (1997) C 339/415.

European Parliament Resolution on the situation and role of artists in the EU, OJ (1999) C $175 / 42$.

Explanatory brochure for Commission Regulation 1400/2002 of 31 July 2002 on the application of Article 81(3) of the Treaty to categories of vertical agreements and concerted practices in the motor vehicle sector.

Green Paper on Copyright in the Knowledge Economy, COM (2008)466, July 2008.

Green Paper on damages actions for breach of the EU antitrust rules, COM (2005)672 Final.

Green Paper on European Union Consumer Protection, COM (2001)531 Final.

Green Paper on the establishment of the common market for broadcasting, especially by satellite and cable, COM (84)300, May 1984.

Green Paper on The Protection of Utility Models in the Single Market, COM (95)370, July 1995.

Green Paper on the Review of the Consumer Acquits, COM (2006)744 Final.

Regulation 648/2012 on OTC derivatives, central counterparties and trade repositories [2012] OJ L201/1. 
Report from the Commission to the European Parliament and the Council, Development and implications of patent law in the field of biotechnology an genetic engineering, COM (2002) 545 final, 7 Oct. 2002.

Resolution 17 of the European Parliament on the typology of acts and the hierarchy of legislation in the European Union [2002] OJ C31E/126.

Staff working papers accompanying the Commission Communication on scientific information in the digital age: access, dissemination and preservation COM (2007)56 Final.

White Paper on damages actions for breach of the EU antitrust rules, COM (2008)165 Final.

White Paper on the modernization of the rules implementing Articles 85 and 86 of the EU Treaty Commission Program No 99/027.

White Paper on the review of Regulation 4056/86, applying the EU competition rules to maritime transport, COM (2004)675 Final.

White Paper, Completing the Internal Market. White Paper from the Commission to the European Council (Milan, 28-29 June 1985). COM (85) 310 final, 14 June 1985. 



\title{
Space Liability Insurance: Concerns and Way Forward
}

\author{
By Sandeepa Bhat B.
}

\begin{abstract}
With the enormous increase in private space activities, the States across the globe have found difficulties in regulating them and protecting common interest in outer space. As the existing international space law imposes liability for any damage caused by private space activities to respective launching State/s, one of the moot questions before the States at present; is how to meet with such everincreasing risk of liability? Space insurance, despite all its drawbacks, is considered as the major mechanism available for discharging liability arising out of space disasters. Hence, space liability insurance as a requirement for grant of licence is found in almost all existing national space legislation. However, this paper argues against it, and looks into the feasibility of establishing space liability fund as an alternative to strike balance between the interests of different stakeholders.
\end{abstract}

Keywords: Insured; Insurer; Risk; Space liability fund; Subrogation.

\section{Introduction}

Space era started with the State oriented scientific activities and subsequently, shifted to private sector oriented commercial activities. However, the five major international treaties governing the outer space ${ }^{1}$ are entered during 1960s and $70 \mathrm{~s}$, which was the era of State oriented space activities. Hence, the norms of liability in these treaties focus on the liability of 'launching State/s' for any damage caused by space activities. This situation continued to exist even after the entry of private sector into the realm of space activities, since the progressive development of space law in the international level halted after the 1979 Moon Agreement. $^{2}$ Therefore, the crucial question for consideration is; how far it is justified to allow the private sector to reap the benefits of space activities and

\footnotetext{
"LL.M., Ph.D. Professor of Law, Coordinator - Society for Studies in Outer Space Law, The WB National University of Juridical Sciences, Salt Lake, Kolkata, India. Member, International Institute of Space Law (IISL), France. Email: sandeep_nls@yahoo.com.

${ }^{1}$ Treaty on Principles Governing the Activities of States in the Exploration and Use of Outer Space, including the Moon and Other Celestial Bodies, 27 January, 1967 (hereinafter Outer Space Treaty); Agreement on the Rescue of Astronauts, the Return of Astronauts and the Return of Objects Launched into Outer Space, 22 April 1968 (hereinafter Rescue Agreement); Convention on International Liability for Damage Caused by Space Objects, 29 March 1972 (hereinafter Liability Convention); Convention on Registration of Objects Launched into Outer Space, 14 January 1975 (hereinafter Registration Convention); Agreement Governing the Activities of States on the Moon and Other Celestial Bodies, 18 December 1979 (hereinafter Moon Agreement).

${ }^{2}$ See generally Tronchetti (2010). See also Davis \& Lee (1999).
} 
ultimately shift the burden of liability on the State/s for damage caused by its space activities?

In light of the above concern, the States have started to insist for insurance coverage to shoulder the burden of liability for damage caused by the private space activities. The initial refusal of insurers to shoulder enormous risk associated with the space activities has been overcome with coinsurance and reinsurance techniques. However, neither coinsurance nor reinsurance works smoothly, since both bank on the cooperation between multiple profit-oriented commercial entities, which are hard to find in practical terms.

Apart from the problems between the insurance providers, the issues arising out of conflicting interests of insurers and insured are standing as impediments in the way of hassle-free space insurance. In the present era of competition driven space industry, every space operator is keen on cutting down his cost of operation to remain competitive in the market. So the operator would be in search of insurance coverage with lower premiums but at the same time not something less effective to cater to his needs. Insurer, on the other hand, would face difficulty in providing such cost effective insurance coverage due to enormous risk involved in space activities. Catastrophic damage is a matter of seconds in the space activities. The disasters in 1980s and Columbia disaster in the twenty first century have got chilling effects on space insurance. It is also to be noted that space insurance has a close nexus with the catastrophic disasters (like 9/11) in the aviation sector. ${ }^{3}$ With every such incident, the space insurance market is structurally changing to meet fresh challenges, thereby affecting the relative position of insurer and insured.

In light of the above aspects, the present paper first delves into the issue of liability for private space activities. Then it goes on to outline the current position of space insurance as a requirement in different countries. The specific problems faced by both the insurers and insured in the space sector are discussed in the next part. Finally, the paper concludes with suggestions to achieve a balanced regime of space insurance, which can take care of the interests of all stakeholders. An attempt is also made to find out the viability of creating a space liability fund as an alternative/supplementary aspect to space insurance.

\section{Liability for Private Space Activities}

Outer Space Treaty 1967, though entered five decades back, still stands as the magna carta of space law. ${ }^{4}$ While Article VI of the Outer Space Treaty attributes responsibility on the concerned States for all types of space activities (whether public or private), Article VII imposes liability for damage caused by space activities on respective launching State/s. Principle of liability under Article VII of the Outer Space Treaty is further supplemented by the Liability Convention 1972. Under the Liability Convention, the launching State/s is absolutely liable to pay compensation for any damage caused on the surface of the earth as well as to the

\footnotetext{
${ }^{3}$ Petras (2007) at 323

${ }^{4}$ Qizhi (1997) at 93.
} 
aircraft in flight. ${ }^{5}$ Similarly, if the damage is caused elsewhere than on the surface of the earth by a space object of one State to a space object or to persons or property on board such space object of another State, the liability for damage between two States involved is determined on the basis of fault. ${ }^{6}$

The Convention also attributes joint and several liability on multiple launching States in two circumstances: First, where there is a collision between the space objects of two or more launching States, which ultimately cause damage to person or property of yet another State ${ }^{7}$; and second, when two or more States have jointly launched the space object that has caused damage to another State ${ }^{8}$. A launching State that has paid full compensation under joint and several liability principles is entitled to receive reimbursement/indemnification from other launching States on the basis of extent of their fault, or on the basis of prior existing agreement on apportionment of liability. ${ }^{9}$

Thus, the space treaties speak solely about the liability of launching State/s and not about the private players. The definition of launching State provided under the Liability Convention ${ }^{10}$ is also wide enough to attribute one or more launching State/s with respect to each private space launch. This leads to the obvious conclusion that for any damage caused by the private space activities, launching State/s would be liable to pay compensation. Moreover, under Article VI of the Outer Space Treaty, the State/s would also shoulder the burden of international responsibility for private space activities. Added to this, neither State responsibility nor international liability under the space treaties can be avoided by the States even in case of absence of their wrongfulness. ${ }^{11}$ These attributes of State responsibility and international liability for private space activities have posed difficulties to the States in the present era of increasing private space investments.

Imposition of liability on the States for damage caused by the private space activities would mean that the public money would be used for payment of compensation for damage arising out of private activities. This goes against the principles of justice and equity especially in light of the fact that the private players would solely reap benefits out of their space activities and point towards their States when the question of liability arises for any damage caused by their space activities. As we know, one of the well-established tenets of equity is that one who reaps benefits must also incur burden. ${ }^{12}$ Failure to adhere to this principle results in compromising the public good for furthering the private interest in space activities. In order to set right this conundrum that has arisen out of the exponential growth of private space activities, States across the globe have insisted the private

\footnotetext{
${ }^{5}$ Liability Convention, art. II.

${ }^{6}$ Liability Convention, art. III.

${ }^{7}$ Liability Convention, art. IV.

${ }^{8}$ Liability Convention, art. V.

${ }^{9}$ Liability Convention, art. IV (2) \& V (2) respectively.

${ }^{10}$ Art. I (c) states: The term "launching State" means: (i) A State which launches or procures the launching of a space object; and (ii) A State from whose territory or facility a space object is launched.

${ }^{11}$ Hermida (1997) at 62.

${ }^{12}$ Bhat \& Bhat (2010)) at 146.
} 
space actors to procure minimum insurance coverage to meet with the liability for damage caused by their activities.

\section{Space Liability Insurance and its Current Position}

Space insurance as a mechanism to shoulder the liability originated in 1965 catering to the third party liability and damage to satellites. ${ }^{13}$ It gained prominence during early 1980s when the commercial satellite industry increasingly resorted to space insurance. However, the United States proclamation of Strategic Defense Initiative in $1983^{14}$, and satellite disasters in mid $1980 \mathrm{~s}^{15}$ have resulted in the collapse of space insurance industry. ${ }^{16}$ This has significantly reduced the number of space insurance providers and increased the premiums by manifold. Subsequently in 1990s, attempts were made to reconstruct the space insurance industry and to restore competition. These efforts were quite successful with the cooperation of insurance companies and resulted in the restoration of healthy competition. Consequently, insurance premiums were reduced to make it affordable to private space actors.

High risk involved in space activities was negotiated by adopting coinsurance and reinsurance techniques especially through the pooling arrangements. While coinsurance involves the joining of several insurance providers to proportionately cover the risk according to their affordability ${ }^{17}$, reinsurance involves the spreading of the burden of coverage provided by one insurer to several other players by way of insurer going for further insurance of his interests with other insurers ${ }^{18}$. Such cooperation between the insurance providers not only resulted in providing space liability insurance coverage but also in satellite insurance and launch vehicle insurance. ${ }^{19}$

Requirement of insurance coverage for shouldering the first tier of liability for private space activities can commonly be seen in the existing national space legislation. The United States laws require maximum $\$ 500$ million insurance coverage for third party liability and $\$ 100$ million insurance coverage to meet claims from government for damage caused to it by private space activities. ${ }^{20}$ In case of any liability, this first tier of compensation by the insurance provider would be exhausted before proceeding to the second tier of payment by United States government subject to a limit of $\$ 1.5$ billion. Australia insists for an

\footnotetext{
${ }^{13}$ van Reeth (1984) at 127.

${ }^{14}$ Popularly known as Star War programme, is designed to develop a space-based anti-ballistic missile system. For details see Reiss (1992).

${ }^{15}$ Destruction of Cosmos 1402 in 1983 and Challenger in 1986 are two examples of such disasters. Added to this, Palapa B2, Westar VI and Intelsat IV missions were lost during the same period. See Manikowski \& Weiss (2007).

${ }^{16}$ Hermida (2010) at 112.

${ }^{17}$ See Rokas (2008) at 54. See also Ratliff \& Tupper (1990).

${ }^{18}$ See Wehrhahn (2009). See also Carranza-Kopper (2010) at 227.

${ }^{19}$ Satellite insurance and launch vehicle insurance are again divided into pre-launch, launch and satellite/launch vehicle life insurance.

${ }^{20} 51$ U.S.C. $\$ 50914(\mathrm{a})(3)(\mathrm{A})$.
} 
insurance coverage of not less than the lesser amount of $\$ 750$ million and maximum probable loss determined as per the regulations. ${ }^{21}$ Austria insists for a minimum insurance coverage of Euro 60 million. ${ }^{22}$ South Korea caps the limit of liability of private space actors at 200 billion Won, which can be subject to insurance coverage. $^{23}$

States like United Kingdom, France, Netherlands, Russia, China, Japan, Singapore and Hong Kong have also come out with the liability insurance requirements. However, they have not specified the amount of insurance coverage to be procured by the space actors in their legislation. ${ }^{24}$ In the absence of specifications, the licensing authorities established under the laws are having the discretion to prescribe the requirement of insurance coverage in specific space activities. United Kingdom ${ }^{25}$ and French authorities have set the insurance coverage limit of Euro 60 million. ${ }^{26}$ Japan, Hong Kong and Singapore require an insurance coverage of $\$ 100$ million. $^{27}$

It is pertinent to note that some of the States have also attempted to ensure that the insurance companies would not try to escape from liability after assuring the coverage. This is very significant because the usual tendency of insurance providers is to ensure coverage at the time of entering into the contract of insurance, and subsequently, when the question of liability arises, they try to avoid it by invoking certain escape clauses. This stands as a serious problem in case of space liability especially because of the possibility of catastrophic damage affecting large number of people. With the legislative or administrative control over insurance companies, such kind of possible misuses can be prevented. Russia, for example, requires the insurance coverage to be obtained either by transmitting insurance premiums to Russian Space Fund or other insurance companies which have obtained licence for space insurance. ${ }^{28}$

\section{Areas of Concerns in Space Liability Insurance}

Even though the world community seems to embrace insurance to offset the risk of space liability, it cannot be considered as the best and infallible mechanism. There are many practical concerns in the space liability insurance. One of the most significant problems faced by the insurance industry is the lack of expertise in the risk evaluation for space activities. Every insurance coverage is dependent on the evaluation and balancing of risk and return factors. ${ }^{29}$ While the high premiums charged for space insurance undoubtedly yield high returns, uncertainties

\footnotetext{
${ }^{21}$ Space Activities Act $1998 \S 48(3)$.

${ }^{22}$ Austrian Outer Space Act $2011 \S 4(4)$.

${ }^{23}$ Space Liability Act 2008 art's 5 \& 6. See Dempsey (2016) at 31.

${ }^{24}$ See for example Outer Space Act 1986 (UK) § 5(2)(f).

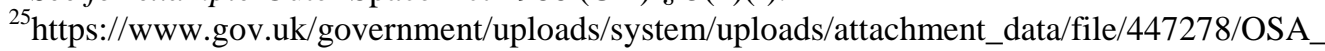
reform_guidance_text_2_.pdf

${ }^{26}$ Gaubert (2012).

${ }^{27}$ Ibid.

${ }^{28}$ Law of Russian Federation about Space Activity 1993, art. 25.

${ }^{29}$ See Bingham (2011).
} 
associated with the risks posed by space activities stand as impediments in providing space insurance. Undoubtedly, a successful space venture is capable of earning huge amount of profits to the space actor, and thereby, the insurance provider would also be in an advantageous position. However, the line of distinction between the success and failure in space activities is very thin, which is reflected in the fact that even a pioneer space agency like NASA has lost its missions. ${ }^{30}$ Moreover, the failed missions are capable of ruining the business of not only the space actors but also that of the insurance providers due to their potentiality to cause catastrophic damage. Hence, the insurers would always face dilemma in providing insurance coverage to space industry, which floats on shaky foundations of risks.

The evaluation of risk for providing insurance coverage to space activities is also hampered by the difficulties in discharging the duty to disclose information by the insurance seeker. Duty to disclose in good faith all material information that would be essential for the insurance provider to underwrite the risk is a bedrock principle of contract of insurance. ${ }^{31}$ However, the space activities involve various high-end technologies, which the space actor would like to sacrosanct protect from disclosure. In the absence of such disclosure, the insurance provider can never fully assess the safety of space venture that is sought to be covered by the insurance. A general estimation of risk would also not be possible due to the fact that each space activities are different in nature and operation, and thus, the risks involved in those activities also differ. Added to this, the magnitude of risk is also dependent on another variable, that is, the space capability of the operator concerned.

Despite the resort to coinsurance and reinsurance techniques, the magnitude of risk of damage involved in space activities still stand as deterrent factor for underwriting space liability insurance. Though we are yet to evidence a catastrophic space disaster in terms of third party liability, Cosmos 954 incident has provided us sufficient insight on such a possibility. ${ }^{32}$ The $9 / 11$ incident has further demonstrated the possibility of damage much beyond what can reasonably be expected by the insurance industry to absorb. ${ }^{33}$ In addition, more frequent use of nuclear power sources in space missions have also scaled up the magnitude of risk in space activities. These factors, especially in the absence of reliable mechanism of safety assessment and risk evaluation, have got serious prejudicial effects on space insurance providers.

Space liability insurance seekers also face several difficulties in protecting their interests with insurance coverage. One of the major concerns of insurance seekers is the effect of exclusion clauses that are imposed on them by the insurance providers while underwriting the insurance. Even though there is a requirement of disclosure of exclusion clauses in good faith ${ }^{34}$, often the insurance companies devise the exclusion clauses in such a clever manner that the insurance

\footnotetext{
${ }^{30}$ See generally Lafleur (2010).

${ }^{31}$ Lowry (2009) at 98.

${ }^{32}$ See Cohen (1984) at 85 and 86.

${ }^{33}$ Jerry II (2002) at 101.

${ }^{34}$ Schwartz (2008) at 105.
} 
seekers would not be able to realise the wide range of operation of exclusion clauses. While the defence of material misrepresentation by the insured is invoked quite frequently during the settlement of claims, war risk and nuclear risk exclusion are commonly found inscribed expressly in most insurance policies. ${ }^{35} \mathrm{In}$ addition, certain grounds of exclusion of coverage found in aviation and other related sectors, like exclusion in case of fault inherent in the project, exclusion of environmental damage, conversion exception ${ }^{36}$ may also be found in space liability insurance.

Insurance contract confers the right of recoupment to insurers under the doctrine of subrogation. ${ }^{37}$ Therefore, a space liability insurance provider may proceed against the insured after the payment of compensation to the victims of accidents. There is also a possibility of the insurer asserting his rights over the space object that has caused damage while exercising the right of recoupment, especially in the circumstances wherein the insurance coverage is obtained for damage to space object as well as third party liability together. This would be detrimental to the interests of the insured, since space objects - whether active or defunct - possess high-end technology and intellectual property rights. Handing over such space object to the insurer would mean free transfer of technology and intellectual property rights, which no reasonable space actor would prefer.

Added to above concerns of insurer and insured, problems may also be faced in the context of duty to mitigate damage, which is one of the essential elements of insurance contracts ${ }^{38}$. This duty, when read in the context of relationship between the insurer and insured, imposes an obligation on the insured to take all reasonable measures to avoid the aggravation of damage arising out of his activities. Upon failure of the insured to take such reasonable measures to mitigate damage, the insurer's liability to pay compensation would be reduced. ${ }^{39}$ Though the onus of proving the failure of insured to take reasonable measures to mitigate damage is on the insurer ${ }^{40}$, it is often found that the insurers have invoked it especially in the cases involving payment of hefty compensation. ${ }^{41}$

As mentioned by Ken Cooper-Stephenson, the defendant needs to prove three factors for a successful claim of mitigation. ${ }^{42}$ When we import these factors to the space liability insurance, the insurer has to establish: (a) steps the insured might have taken to avoid the loss; (b) that it would have been reasonable for the insured

\footnotetext{
${ }^{35}$ Abeyratne (2003) at 201.

${ }^{36}$ Riddle (2005) at 419 . Though the author referred herein has highlighted the conversion exclusion in light of using aircrafts for unlawful purposes, the same principle may be applicable to those cases wherein the insured alters the status or functions of space object without the consent of insurer.

${ }^{37}$ Tye (1952) at 386.

${ }^{38}$ See Darbishire v. Warran [1963] 3 All ER 310; see also Lombard North Central Plc. v. Automobile World (UK) Ltd. [2010] EWCA Civ. 20.

${ }^{39}$ Fischer (2013) at 90.

${ }^{40}$ See Red Deer College v. Michaels [1976] 2 S.C.R. 324; see also Janiak v. Ippolito [1985] 1 S.C.R. 146.

${ }^{41}$ See for example, Lombard North Central Plc. v. Automobile World (UK) Ltd. [2010] EWCA Civ. 20; Gordon Chem. Co. v. Aetna Cas. \& Sur. Co., 358 Mass. 632, 266 N.E.2d 653 (1971); Northwestern State Portland Cement Co. v. Hartford Fire Ins. Co. 360 F.2d 531 (8th Cir. 1966); and Baxter Inter., Inc. v. American Guarantee and Liability Ins. Co. 861 N.E. $2 d 263$ ( $1^{\text {st }}$ Dist. 2d 2006).

${ }^{42}$ See Cooper-Stephenson (1996) at 868.
} 
to take such action; and (c) the extent to which the loss would have been reduced if the steps had been taken. ${ }^{43}$ Since the duty to mitigate damage banks on the reasonableness standard, critical problems would arise in space insurance. While reasonableness varies from person to person ${ }^{44}$, repetitive practices are referred by the courts to arrive at conclusions on reasonableness ${ }^{45}$. However, in space activities, such repetitive practices are not found due to the differences in nature and conduct of each space ventures. ${ }^{46}$ Hence, the determination of reasonable measures that could have been taken by the insured to mitigate damage is ultimately dependant on the court's findings on the basis of factors best known to the individual judges concerned. Leaving such an amount of discretion to judges in deciding issues under space insurance, which usually involve high-stakes, would be detrimental to the interests of different stakeholders. It is pertinent to note here that in space liability insurance, the stakeholders involved are not only the insured and the insurer, but also the victims of space accidents. Therefore, allowing the insurer to take the defence of failure of insured to mitigate damage would in turn mean the depravation of rights of third party victims in getting compensation. Moreover, the subjectivity involved in testing the reasonable measures to mitigate damage in space accidents may also take away the essential element of predictability in the process of decision-making, which hits the very basis of justice delivery system. ${ }^{47}$

\section{Conclusion and the Way Forward}

Despite the developments in technology, space activities pose significant risk of damage to those involved in space activities as well as others, who might become third party victims of mishaps. The space treaties, being drafted in the era of State-oriented space activities, impose liability only on States for causing any damage by their space activities. However, with the development of private space activities, applying the same principle of liability to hold the States liable for the misdeeds of private players does not hold well in terms of justice and equity. Without any doubt there is a requirement of reliving States from such unjustifiable burden of liability to prevent the sacrifice of common interest in the zeal of promoting individual interest of private players.

Devising the requirement of space insurance as a mechanism to shift such State liability has been found useful in the recent past. However, it is not certain to work in the long run due to the above discussed concerns in the space insurance. As of now, these problems are not in the limelight due to the absence of any major space disaster. With the increase in space activities and unabated increase in debris creation, the risk of collision in outer space is increasing by

\footnotetext{
${ }^{43}$ Ibid.

${ }^{44}$ Moore \& Gaudreau (2013).

${ }^{45}$ Hevia (2013) at 82.

${ }^{46}$ Dembling (1970) at 88 .

${ }^{47}$ Predictability of judgements as a principle is strongly rooted in common law. See generally Atiyah (1992).
} 
manifold. Moreover, the use of nuclear power sources in space activities adds on to the concerns of risk of damage that may be caused by space activities. If the unfortunate event of catastrophe happens in the future, the insurance companies concerned would certainly try their best to avoid payment of compensation to the victims by misusing the grey areas of space insurance.

In a high risk venture like space activities, balancing of interests of different stakeholders attains greater significance. Interests of the insurer, insured and third party victims need to be balanced in the space insurance. Given the limited number of space insurance providers, the insurers seem to have an upper hand in tailoring the space insurance policies. The space actors (insured) would in most circumstances have no option but to accept the terms and conditions of insurer. This may not only compromise their interests but also that of third party victims. Hence, in the current scenario, State regulation of space insurance industry is essential to negate the relatively advantageous position of insurers and strike a balance between conflicting interests of stakeholders.

For a long term solution to the space liability concerns, gradual move towards the creation of space liability fund is advisable. Such a fund may operate at both national and international levels. At the national level, analogy can be drawn with the working model of nuclear liability fund created in the United States. PriceAnderson fund created under the Price-Anderson Act 1957 has grown big enough to meet with liability needs arising out of any nuclear disaster in the United States. ${ }^{48}$ Similar attempt has also been done in India under the Civil Liability for Nuclear Damage Act 2010. ${ }^{49}$ In the field of space activities, Russian Federation has already brought in the requirement of establishing Russian Space Fund under its national space legislation. ${ }^{50}$ This Fund may be utilised for payment of compensation in case of damage caused by space activities. ${ }^{51}$ Again in the international level, creation of liability funds can be seen in the nuclear liability regime. Convention on Supplementary Compensation 1997 and Brussels Supplementary Convention 1963 as amended by 2004 Protocol are two major examples of creating international liability fund.

The proposed space liability fund can be created by way of contributions from each space actor, which may be fixed as a certain percentage of profits made out of their space activities. In comparison to space insurance, the space liability fund has its own advantages: First, it would be a permanent fund unlike space insurance, which lapses and has to be obtained separately for each space activity. Second, the space liability fund would be ever-growing with continuing contributions from space actors. In contrast, the space insurance premiums are forfeited after the lapse of insurance period, and therefore, no corpus is created in space insurance. Third, the space liability fund operates on the basis of collective responsibility of space

\footnotetext{
${ }^{48}$ See Elizabeth \& Bergan (2011) at 279.

${ }^{49}$ Civil Liability for Nuclear Damage Act $2010 \S 7$ (2) states; "For the purpose of meeting part of its liability under clause (a) or clause (c) of sub-section (1), the Central Government may establish a fund to be called the Nuclear Liability Fund by charging such amount of levy from the operators, in such manner, as may be prescribed."

${ }^{50}$ Law of Russian Federation about Space Activity 1993, art. 13.

${ }^{51}$ Law of Russian Federation about Space Activity 1993, art. 25.
} 
industry to make good the loss caused by individual space activities, which helps in sharing of burden. However, the space insurance is based on individual responsibility of space actor to procure adequate insurance coverage to compensate damage. Fourth, as a logical extension of the above point, the victims of space disasters are better assured of compensation in the space liability fund model when compared to space insurance model. This is due to the fact that neither the space actor nor the insurance provider, acting individually, would be capable of compensating catastrophic damage. Even if the insurance companies are adopting the coinsurance and reinsurance techniques, they would not be able to match with the enormous potentiality of space liability fund to absorb liability. A key factor of distinction that may be noted in this regard is that the coinsurance and reinsurance essentially involve many profit-oriented insurance companies and the space liability fund is free from them. Thus, when the element of profit is excluded in the compensation regime, the fund available for compensation would invariably be more.

Finally, the author finds that the space liability fund provides a better protection to victims of space disaster, and also helps the States to shift their onerous burden of liability for private space activities. At the same time, the space actor would not be subject to any additional burden, since the amount that he should have paid as insurance premium might just have to be contributed to the space liability fund. Thus, the space liability fund stands as an interesting option available for rebalancing the interests of different stakeholders in the existing imbalanced space liability regime.

\section{References}

Abeyratne, R. (2003). 'Synergies and Problems in Outer Space Insurance and Air Transport Insurance' in Transp. L.J. 30:189-211.

Atiyah, P. S. (1992). 'Justice and Predictability in the Common Law' in Unsw L.J. 15:448461.

Bhat, B.S. \& Bhat, P.I. (2010). 'Legal Framework of State Responsibility and Liability for Private Space Activities' in Bhat B.S. (ed.) (2010) Space Law in the Era of Commercialisation. Lucknow: Eastern Book Company, at 131-149.

Bingham, R.E. (2011). 'Risk and Return: Underwriting, Investment and Leverage . Probability of Surplus Drawdown and Pricing for Underwriting and Investment Risk'. Available at http://www.casact.org/library/00pcas/bingham.pdf

Carranza-Kopper, E. (2010). 'Fronting Arrangements: Industry Practices and Regulatory Concerns' in Conn. Ins. L.J. 17: 227-252.

Cohen, A.F. (1984). 'Cosmos 954 and the International Law of Satellite Accidents' in Yale J. Int'l L. 10:78-91.

Cooper-Stephenson, K. (1996). Personal Injury Damages in Canada. $2^{\text {nd }}$ ed. Scarborough: Carswell.

Davis, M. \& R.J. Lee (1999). 'Twenty Years after the Moon Agreement and its Legal Controversies" in 1999 Austl. Int'l L.J. 9-32.

Dembling, P.G. (1970). 'Establishing Liability for Outer Space Activities' in Proceedings of the Thirteenth Colloquium on the Law of Outer Space (Constance, Germany, October 4-10, 1970). William S. Hein, Incorporated, 1971, at 87-97. 
Dempsey, P.S. (2016). 'National Laws Governing Commercial Space Activities: Legislation, Regulation \& Enforcemen' in Nw. J. Int'l L. \& Bus. 36:1-44.

Fischer, J.M. (2013). 'Does an Insured have a Duty to Mitigate Damages When the Insurer Breaches?' in Conn. Ins. L.J. 20:89-117.

Gaubert, C. (2012). 'Can space insurance offer workable solutions for outer space sustainability', available at http://iislweb.org/docs/2012_Gaubert.pdf

Hermida, J. (1997). Commercial Space Law: International, National and Contractual Aspects. Buenos Aires: Ediciones Depalma..

Hermida, J. (2010). 'Space Insurance' in Bhat B.S. (ed.) (2010) Space Law in the Era of Commercialisation. Lucknow: Eastern Book Company, at 111-130.

Hevia, M. (2013). Reasonableness and Responsibility: A Theory of Contract Law. Dordtrecht: Springer.

Jerry II, R.H. (2002). 'Insurance, Terrorism, and 9/11: Reflections on Three Threshold Questions' in Conn. Ins. L.J. 9: 95-120.

Lafleur, C. (2010). 'Spacecraft stats and insights' in The Space Review. (Apr. 5, 2010). Available at http://www.thespacereview.com/article/1598/1.

Lowry, J. (2009). 'Whither the Duty of Good Faith in UK Insurance Contracts' in Conn. Ins. L.J. 16: 97-156..

Manikowski, P. \& M.A.Weiss (2007). The Satellite Insurance Market and Underwriting Cycles. Available at http://www.aria.org/meetings/2007papers/IIIB\%20-\%202\%20$\% 20$ Mani kowski.pdf.

Moore, S.R. \& S. Gaudreau (2013). 'Mitigation in Personal Injury Cases', http://www.bla ney.com/files/MitigationPersonalInjuryCases_SMoore_SGaudreau_2013.pdf

Petras, C. M. (2007). 'An Alternative Proposal to Modernize the Liability Regime for Surface Damage Caused by Aircraft to Address Damage Resulting from Hijackings or Other Unlawful Interference' in Gonz. J. Int'l L. 10:315-339.

Qizhi, H. (1997). 'The Outer Space Treaty in Perspective' in J. Space L. 25:93-100.

Ratliff, J. \& S. Tupper (1990). 'Competition Law and Insurance: Recent Developments in the European Community' in Int'l Bus. Law 18:352-358.

van Reeth, G. (1984). 'Space and Insurance' in Int'l Bus. Law 12:127-131.

Reiss, E. (1992). The Strategic Defense Initiative. Cambridge: Cambridge University Press,

Riddle, G. H. (2005). 'Aviation Insurance Coverage Issues Beware the Renter Pilot' in $J$. Air L. \& Com. 70:407-428.

Rokas, I. (2008). 'Multi-Jurisdictional Issues - Dealing with Uncertainty in the Insurance Field' in Ins. L.R. 3:54-55.

Schwartz, D. (2008). 'Interpretation and Disclosure in Insurance Contracts' in Loy. Consumer L. Rev. 21:105-154.

Tronchetti, F. (2010). 'The Moon Agreement in the $21^{\text {st }}$ Century: Addressing Its Potential Role in the Era of Commercial Exploitation of the Natural Resources of the Moon and Other Celestial Bodies' in J. Space L. 36:489-524.

Tye, C.W. (1952). 'Salvage and Subrogation Problems' in Ins. L. J. (ii) 386-388.

Wehrhahn, R. (2009). 'Introduction to Reinsurance' in Premier Series on Insurance.2:1-2. http://siteresources.worldbank.org/EXTFINANCIALSECTOR/Resources/2828841242281415644/Introduction_to_Reinsurance.pdf.

Wilson, E. J. \& S Bergan (2011). 'Managing Liability: Comparing Radioactive Waste Disposal and Carbon Dioxide Storage' in Toth, F. L. (ed.) (2011) Geological Disposal of Carbon Dioxide and Radioactive Waste: A Comparative Assessment. Dortrecht: Springer, at 263-294.

http://space.stackexchange.com/questions/1659/what-is-the-success-rate-of-nasa-launches 


\section{Treaties}

Agreement Governing the Activities of States on the Moon and Other Celestial Bodies: Dec. 18, 1979 (= Moon Agreement), 18 ILM 1434, 1363 U.N.T.S 3.

Agreement on the Rescue of Astronauts, the Return of Astronauts and the Return of Objects Launched into Outer Space: Apr. 22, 1968 (= Rescue Agreement), 19 U.S.T. 7570, 672 U.N.T.S. 119.

Convention on International Liability for Damage Caused by Space Objects: Mar. 29, 1972 (=Liability Convention), 24 U.S.T. 2389, 961 U.N.T.S. 187.

Convention on Registration of Objects Launched into Outer Space: Jan. 14, 1975 (=Registration Convention), 28 U.S.T. 695, 1023 U.N.T.S. 15.

Treaty on Principles Governing the Activities of States in the Exploration and Use of Outer Space, including the Moon and Other Celestial Bodies: Jan. 27, 1967 (=Outer Space Treaty), 18 U.S.T. 2410, 610 U.N.T.S. 205.

\section{Legislation}

\section{Australia}

Space Activities Act 1998

\section{Austria}

Austrian Outer Space Act 2011

\section{India}

Civil Liability for Nuclear Damage Act 2010

\section{Republic of Korea}

Space Liability Act 2008

\section{$\underline{\text { Russia }}$}

Law of Russian Federation about Space Activity 1993

$\underline{\text { UK }}$

Outer Space Act 1986

\section{USA}

51 U.S.C. $\S 50914(\mathrm{a})(3)(\mathrm{A})$.

\section{Cases}

\section{USA}

Baxter Inter., Inc. v. American Guarantee and Liability Ins. Co., 861 N.E. $2 d 263$ ( $1^{\text {st }}$ Dist. 2d 2006)

Gordon Chem. Co. v. Aetna Cas. \& Sur. Co., 358 Mass. 632, 266 N.E.2d 653 (1971)

Northwestern State Portland Cement Co. v. Hartford Fire Ins. Co. 360 F.2d 531 (8th Cir. 1966) 


\section{$\underline{\mathrm{UK}}$}

Darbishire v Warran [1963] 3 All ER 310

Lombard North Central Plc. v Automobile World (UK) Ltd. [2010] EWCA Civ. 20

\section{Canada}

Janiak v Ippolito [1985] 1 S.C.R. 146

Red Deer College v Michaels [1976] 2 S.C.R. 324 



\title{
Judicial Case Management: The Stay of Pending Claims in Repetitive Cases Provided by the Brazilian Civil Procedure Code of 2015
}

\author{
By Larissa Clare Pochmann Da Silva*
}

\begin{abstract}
This paper analyses the judicial case management from the determination of stay of pending claims on the occasion of the trial of repetitive cases in Brazil. To this end, it begins by highlighting the relevance of judicial case management in enhancing civil justice. It then explains the meaning of repetitive claims before going into the study of the stay of pending claims. After examining the topic, it observes that the stay of pending claims is a mechanism that, in the medium and long term, may be relevant both to the improvement of the jurisdictional performance, avoiding contradictory decisions, and ensuring speed, allowing, after fixing the thesis, the Judiciary can focus on non-repetitive cases.
\end{abstract}

Keywords: Judicial Case Management; Brazilian Civil Procedure Code of 2015; Stay of Pending Claims; Repetitive Claims

\section{Introduction}

The present paper analysis of the powers of the judge in view of the provision of the Brazilian Civil Procedure Code of 2015 of the stay of pending claims in the trial of repetitive cases, focusing on two questions in the Brazilian's procedural law scene: i) which are the power of judges in pending claims; ii) how do they work.

For this, through a qualitative approach, the work begins highlighting the relevance of judicial case management in the context of the improvement of civil justice. Then, it is mentioned the concept of judgment of repetitive cases and, finally, the powers of the judge are approached in the perspective of the stay of pending claims.

\section{Judicial Case Management in the Context of the Improvement of Civil Justice}

In 1975, Mauro Cappelletti dealt with a real revolution in the Judiciary, with the gradual abandonment of essentially individualist and liberal paradigms for the

\footnotetext{
*Post-doctoral Researcher in Procedural Law at Rio de Janeiro State University (UERJ). LLD and Master Degree in Law from Estácio de Sá University (UNESA). Professor of Civil Procedure at Candido Mendes University (UCAM) and Estácio de Sá University (UNESA). Lawyer. Email: larissacpsilva@gmail.com.
} 
adequacy of procedure to social transformations, whose manifestations would be both in the improvement of the individual claims and the development of the collective actions ${ }^{1}$.

After more than 40 years of this prediction, the revolution treated by Cappelletti was not able to generate a true metamorphosis of civil justice, but it is undeniable that some transformations have occurred over the years ${ }^{2}$. These transformations are mainly focused on a major dilemma of civil justice ${ }^{3}$, which is the pursuit of balance between efficiency and quality of conflict resolution.

To balance efficiency and quality, the procedural reforms have sought, in essence, not only accelerate, but also improve the procedural rules ${ }^{4}$. For this, in addition to legislative changes, even with a view to summarizing the procedure, some countries began to worry about the availability of official empirical data referring to the judiciary, in order to monitor their results. The follow-up occurs, depending on the region treated, with greater or lesser detail, but can be exemplified, within the European Union, by the studies developed by the European Commission for the Efficiency of Justice (CEPEJ) ${ }^{5}$; in the United States, by the studies developed by Federal Judicial Center ${ }^{6}$ and Uscourts $^{7}$ and in Brazil, through the data available by the National Council of Justice $(\mathrm{CNJ})^{8}$.

In turn, there is also a greater concern with the system of conflict resolution, recognised as imbued with extreme complexity, formalism and costs. The aim is to encourage alternative forms of conflict resolution, so that the judicial process does not show the only way to solve conflicts.

Judicial case management is only one of the strategies that were adopted, both in national courts and in international courts, for the improvement of civil justice. During the history, the rules were developed to provide power to the judges to manage the formalities of judicial proceedings, regulating the progress of disputes, in order to reduce the length and increase the quality of the trial.

It should be emphasised that what is understood as judicial case management does not involve the adoption of a single technique, consisting of different and often combined methods ${ }^{9}$. These techniques can be exemplified as the determination and supervision of the deadlines established for the practice of procedural acts in order to reduce the length of the procedure; the adoption of techniques for summarizing the procedure; techniques to interrogate witnesses; recording of evidence; alternative dispute resolution mechanisms and valuing precedents.

Nowadays, there are several judicial case management records in national and international courts. References to judicial case management are common in the

\footnotetext{
${ }^{1}$ Cappelletti (1975) at 571-572.

${ }^{2}$ Uzelac \& Van Rhee (2018) at 4.

${ }^{3}$ The expression "civil justice" is addressed in this text as the non-criminal sphere and without covering labour justice.

${ }^{4}$ Uzelac \& Van Rhee (2008) at 1.

${ }^{5}$ Dynamic database of European judicial systems.

${ }^{6}$ Database of American judicial systems.

${ }^{7}$ Statistics and Reports.

${ }^{8}$ Statistics and Reports.

${ }^{9}$ Schwarzer (2006) at 1
} 
English Model ${ }^{10}$ and in the North American Model ${ }^{11}$. Within the framework of the European Union, the adoption of judicial case management has been recommended as one of the best practices for higher courts ${ }^{12}$ and the reference to the theme in Latin America grows ${ }^{13}$.

In Brazil, the judicial case management was not inaugurated with the advent of the Code of Civil procedure of 2015, deserving the following powers of the judge foreseen in the Code of Civil Procedure of 1973: I) stay of pending proceedings; II) powers to decide about their own competence; III) try to reconcile the parties at all times of the procedural march; IV) apply fines; (v) anticipate the effects of the decision; VI) decide on the production of evidence, as well as actively participating in its production ${ }^{14}$. However, it was from March $18^{\text {th }}, 2016$, with the entry into force of the new Civil Procedure Code, that the subject had a clear emphasis. It can be mentioned, as an example, the cooperation provided for in article 6 of the Code of Civil Procedure; the possibility of putting claims together to prevent contradictory decisions; the power of the judge provided for article 139, including to carry out its provisions by means of atypical measures and to change the order of proof; the powers of the judge in winding-up proceedings, as provided for article 375; the decision of redistributing the burden of proof, provided by article $373, \S 1$, in addition to the performance of the judge in the distinction of the cases in which they will render a decision before legal theses fixed in repetitive cases, under the terms of article 489, VI, and 1,037, paragraph 9 , as well as the analysis and determination of suspension or not of the processes from the judgment of repetitive cases.

In the present work, the analysis will be delimited to the powers of the judge in view of the stay of pending claims in the trial of repetitive cases.

\section{The Trial of Repetitive Cases in Brazil}

Article 928 of the Civil Procedure Code mentions that repetitive cases are the instruments of the incident of resolution of repetitive demands (IRDR) and repetitive appeals, mechanisms that the decision of material or procedural common questions are binding.

Article 927, section III, of the Civil Procedure Code remembers its binding effect that should be observed by judges and courts in the territorial boundaries in which they were fixed.

According to the lessons of Luiz Guilherme Marinoni, Sérgio Cruz Arenhart and Daniel Mitidiero

Rigorously, the judgment of any and all questions could be repeated, by the mere fact that the questions may be repeated - albeit in different cases. Hence, the incident of

\footnotetext{
${ }^{10}$ Rules 3.1 to 3.21 of Civil Procedure Rules.

${ }^{11}$ Rule 16 of Civil Procedure Rules. See Schwarzer (2006) at 2.

${ }^{12}$ Dusséaux (2017).

${ }^{13}$ Odgers \& Madurera (2019). See also Silva (2010); Ballesteros (2018); and Cabral (2018).

${ }^{14}$ Silva (2010) at 116.
} 
resolving repetitive demands cannot have the same object of repetitive resources: while the incident aims to solve repetitive cases, the special resource aims to form precedents. They are projections of the different functions that each of the cuts, charged with their judgments, takes effect.

That is why we need to resize the scopes of each of the institutes mentioned by art. 928, CPC. The incident of resolving repetitive demands aims to solve cases marked by individual homogeneous rights. Repetitive appeals - such as any extraordinary or special appeals - are aimed at resolving issues for the formation of precedents. ${ }^{15}$

On the incident of resolution of repetitive demands, specifically dealt with in articles 976 to 987 of the Civil Procedure Code, comments Professor Aluisio Gonçalves de Castro Mendes that

The IRDR is returned, mainly, for the rationalisation of judgments, from the solution of common legal issues that are repeated in countless claims and which are thoroughly appreciated by judges, who often arrive at several conclusions. ${ }^{16}$

In turn, the repetitive appeals are provided by articles 1,036 to 1,041 of the Code of Civil procedure. Professor Cassio Scarpinella Bueno comments that:

With the aforementioned multiplicity of extraordinary or special appeals on the basis of the same question of law - the same thesis of constitutional law or federal legal law to focus on concrete cases equal in essence-it is fitting that some appeals are selected and decided by the STF or the STJ, with the remainder of all others, in the expectation that the solution given in cases judged by those courts is applied and observed by all other courts. ${ }^{17}$

Thus, the stay of pending claims will be addressed both in the incident of resolution of repetitive demands and repetitive appeals.

\section{The Application of Judicial Case Management to the Stay of Pending Claims in the Trial of Repetitive Cases}

At this time, the judicial case management in relation to the stay of pending claims will be first analysed in relation to the repetitive appeal procedure and then in the procedure of the incident of resolution of repetitive demands.

\section{The Stay of pending Claims in the proceeding of Repetitive Appeals}

In the context of repetitive appeals, the Civil Procedure Code of 2015 provides in two moments the stay of pending claims: i) one, determined by the court in which the multiplicity of appeals was identified and selected and II)

\footnotetext{
${ }^{15}$ Marinoni, Arenhart \& Mitidiero (2016) at 208.

${ }^{16}$ Mendes (2017) at 10.

${ }^{17}$ Bueno (2019) at 763 .
} 
another at the time of the decision to affect, as determined by the Judge of the Superior Court or the Supreme Court.

In the first, by identifying and selecting appeals for judgment as repetitive in the Superior Court of Justice or the Supreme Court, the president or vice-president of the Court of origin (State Court or Federal Court) will determine the stay of all pending claims, individual or collective, which is in the state or region according to the provisions of article $1,036, \S 1$ of the Code of Civil Procedure.

The second paragraph of article 1,036 provides that, from that first determination of the stay of the claims, claimants can require the president or the vice-president of the Court to exclude special appeal or the extraordinary appeal that has been interposed after the deadline. Although it does not provide an express deadline for such an application, the claimant will have a period of five (5) days to manifest on that application, it is better to interpret that the deadline for formulating the application will also be five (5) days from the science of the decision of the stay of the claims, according to the provision of article $218, \S 3$ of the Civil Procedure Code, as for the realisation of the equality.

In the second stage, article 1,037, II, of the Civil Procedure Code stipulates that the judge in the Superior or in the Supreme Court shall determine the stay of all pending, individual or collective proceedings, on the same issue on the national territory. The admission of the procedure would thus increase the stay of pending claims for the entire country, not encompassing the completeness of the process involving other issues, including because there is a provision on the code of the partial judgment of the merit ${ }^{18}$.

The stay of pending claims, pursuant to article $1,037, \S 4$, shall endure for a maximum period of up to one (1) year until the appeal is judged. If there is no trial within this period, the provision of article $1,037, \S 5$, which provided for the automatic cessation of the stay of the claims pending, after the expiry of the period of 1 year for the judgment of the representative appeal of the dispute, has been revoked. However, considering the provisions of article 5, section LXXVIII, of the Federal Constitution, on the reasonable duration of the proceeding, it seems appropriate that, if there is no express decision of the judge of the Supreme Court or the Superior Court of Justice extending the period, all the claims in the country will continue ${ }^{19}$.

According to article 982, $\S 2$ of the Civil Procedure Code, the requirement of urgent measures will be to the judge of the pending claim.

Pursuant to article 1,037, $\S 8$ of the Civil Procedure Code, parties must be summoned from the stay of their proceedings, by the judge of the first instance or by the Court, depending on the stage of the proceeding, by virtue of the determination contained in the decision to affect.

\footnotetext{
${ }^{18}$ See Arruda Alvim (2019).

${ }^{19}$ Based on the principle of the reasonable duration of the proceeding, the Superior Court of Justice has already admitted the continuation of a proceeding, with the judgment of the special appeal pending, after the exhaustion of the suspension period marked under Of the Federal Supreme Court. See STJ. EDcl method in Resp N ${ }^{\circ}$ 1269617/MS. Min. Paulo de Tarso Sanseverino. Judgment: September, 26, 2014.
} 
Paragraphs ninth to thirteen of the same law bring an important prediction: the distinguish of the case in relation to what will be decided in the repetitive proceeding. This provision (article $1,037, \S 10$ ) will be to the judge to whom the claim is.

Whereas paragraph 11 provides that the other claimants shall have the period of 5 (five), the deadline for formulating the distinguish shall be five (5) days from the science of the suspension. It will then be decided and that decision (article $1,037, \S 13$ ) is appealed by an interlocutory appeal if the case is at the first instance or internal interlocutory appeal if the decision was rendered by a judge in Court, the rapporteur. If the distinction is recognised (article 1,037, $\S 12$ ), the judge or rapporteur will continue the proceedings.

However, it should be noted that the stay of pending claims provided by the legislator is not always mandatory. The Superior Court of Justice has determined the stay of pending claims only can be applied if the decision is later than March $18^{\text {th }}, 2016$, date of entry into force of the Civil Procedure Code of 2015. When the affectation was previous, the stay of only appeals was determined, as can be inferred from the themes of repetitive appeals numbers 313, 949, 950 and 951. In issue number 953, Minister Marco Buzzi, in a decision delivered on May $11^{\text {th }}$, 2016, determined just the remaining of special appeals.

Moreover, the Special Court of the Superior Court of Justice, in the judgment of the Resp 1,202,071-SP, of the Rapporteur of the Minister Herman Benjamin, on February $1^{\text {st }}, 2019$, when analyzing the stay of pending appeals recognised that:

The overthrow of the processing of hundreds or thousands of deeds nationwide, for an indefinite time, does not match the Principles of efficiency and access to the judiciary, especially when there is a possibility for the rapporteur to suspend the achievements in which progress can cause legal uncertainty.

This is the recognition that the stay of pending claims will not always be adequate, especially when the issue is about procedural law that usually involves different claims.

The Stay of pending Claims in the Proceeding of Incident of Resolution of Repetitive Demands

Article 982, paragraph I, of the Civil Procedure Code provides that, if the incident is admitted, the judge in Court shall suspend the pending, individual or collective proceedings, which are in the State or in the region. Initially, the stay of pending claims is only in the court that will judge the incident of resolution of repetitive demands.

The determination of stay o pending claims comes from the judge that is the rapporteur of the incident of resolution of repetitive demands, but it is up to the court to communicate to the competent courts (article $982, \S 1$ ), so that each judge will make the stay of the pending claims in their area. 
Although the law only foretell the stay of pending claims, as analysed by Professor Aluisio Gonçalves de Castro Mendes ${ }^{20}$ :

A deeper reflection on the cogent character should be coincidental with the need for concrete analysis, at the end of the adequacy and eventual limits for the stay of pending claims about the resolution of the common question submitted to the incident of resolution of repetitive demands, even if, as a rule, the legislator has foreseen the stay of pending claims, pursuant to article 982, item I, of the Code of Civil Procedure. Reasons may exist, however, for the non-adoption of the concrete situation.

As analysed in repetitive appeals, here, the stay of pending claims could also be partial.

Article 980 expressly stipulates that the period of stay of pending claims shall be 1 (one) year, which shall be counted from the publication of the decision determining the stay of the claims. After this period, the stay of pending claims shall cease, unless the rapporteur decides to postpone the claims pending. The legislator did not foresee a deadline for this extension, but it should not, however, represent an affront to the reasonable length of the proceedings.

In the provisions on the incident of resolution of repetitive demands, there was no express the possibility to distinguish the repetitive case of the case that is being analysed. Thus, they apply to the incident of resolution of repetitive demands the prediction of article 1,037, $\$ 9$ to 13 of the Code of Civil procedure, regarding the distinguish. ${ }^{21}$

The stay of pending claims under the court also states that who has standing according to sections II and III of article 977, i.e. parties, public prosecution or public defender, may require the superior court to stay of all pending proceedings, individual or collective, which refer to the subject matter of the incident already established, and are underway in the national territory, in accordance with article $982, \S 3$ to $\S 5$. It does not depend, for this application, on the location of the national territory in which the issue is being discussed.

In order for this measure to be required, the incident must already have been admitted, not only that it has been raised.

The national stay of pending claims was measured by the legislator in favour of legal certainty, in accordance with article 982, $\S 3$, but it also seeks the procedural economy, since, from a single incident of resolution of demands it will be possible to standardise the issue at national level.

However, Luiz Guilherme Marinoni, Sergio Cruz Arenhart and Daniel Mitidiero mentions that

Only decision would be indispensable to legal certainty, but this could be achieved in spite of the litigants, who, in the logic of the legislator, regardless of the place of the country in which they are located, may have the exercise of their constitutional rights of action suspended without any appropriate representative being called to act on his behalf. $^{22}$

\footnotetext{
${ }^{20}$ Mendes (2017) at 185 .

${ }^{21}$ Mendes (2017) at 193.

${ }^{22}$ Marinoni, Arenhart \& Mitidiero (2016b) at 97.
} 
It complements article $1,029, \S 4$, which will be for the Superior or the Supreme Court, when deciding to extend the suspension to the national level, if: I) is relevant for legal certainty; II) exceptional social interest and not many stays of the pending claims have been extended to the whole country.

If the suspension is given to the national level, after the incident is judged by the court, who has standing will appeal to the Superior or the Supreme Court to decide the matter for the whole country. If there is no appeal until the deadline, claims will continue.

The Stay of pending Claims from the Perspective of the Improvement of Civil Justice

The stay of pending proceedings due to the judgment of repetitive cases involves the judicial management of proceedings both in relation to the judges of the repetitive trial, as in relation to the judges of each case that is pending.

The judge of the repetitive trial may decide, by affecting the judgment, not to stay the pending proceedings, but also if the determination of stay of the proceedings has occurred and there is no trial within one (1) year, if it would be necessary to extension of the decision, by weighing the relevance that pending proceedings await another time, to avoid contradictory decisions, and the reasonable duration of the proceedings.

In turn, in relation to the judges of each pending case, there is the fulfilment of the determination rendered, through the evaluation of which processes discuss the same question to be decided or which situations are different it means, the distinguish.

After the trial of the repetitive case, all other claims will return to the procedure, with the application of the legal thesis, as preceded by article 985 of the Code of Civil procedure for the incident of resolution of repetitive demands and 1,040 and 1,041 for the repetitive appeals.

If, initially, the stay of pending claims may compromise the reasonable length of the procedure, because the claim would have a longer length while awaiting the decision of the legal thesis, of binding efficacy, according to article 927, III of Civil Procedure Code, after its definition the improvement of the judicial provision is expected.

After the judgment of repetitive claims, all the judges will apply or distinguish the claim and the procedural that was judged by the Court, based on article $489, \S$ 1, paragraph VI of the Civil Procedure Code. This decision don't need to obey the chronological order of judgment (article 12, § 2, item II) and can apply the institutes of the preliminary judgment of dismissal (article 332) and the evidence measure (article 311), so it`s possible to the Judiciary to concentrate on the judgment of non-repetitive issues. 


\section{Conclusion}

The judicial case management was one of the measures adopted in several countries to seek the improvement of civil justice, trying to bring the balance between efficiency and celerity. However, it is worth noting that what is called judicial case management is a set of techniques, which can encompass both the procedure and other forms of conflict resolution.

In Brazil, the theme did not emerge with the advent of the Civil Procedure Code of 2015, but from it had a clear emphasis. The work ended up limited to the judicial case management of repetitive cases, more precisely on the stay of pending cases due to the trial of repetitive claims. To do this, before entering the analysis of the stay of pending claims itself, it is possible to delimit that the repetitive case judgments cover both the incident of resolution of repetitive demands and repetitive appeals.

The determination of stay of pending claims, although foreseen by the legislation, is not mandatory, and there are also cases in decisions given in the context of the Superior Court of Justice or the Supreme Court of Justice. The decision to stay claims pending or not be rendered by the judge of the incident resolving repetitive appeals. In a systematic interpretation of the provision of repetitive appeals and in favour of the reasonable length of the claims, that the prediction of the deadline of up to 1 (one) year for the stay of the proceedings due to the pending judgment planned for the incident of resolution of repetitive demands. Thus, after this period, without the judgment being delivered, unless the rapporteur expressly decides, the stay of pending claims would cease.

The enforcement of the decision is made by each judge and the stay of pending claims may also be partial. It is up to each judge to assess whether the case of his/her rapporteurs has a question identical or not to what will be appreciated in the repetitive trial, with the interested parties within five (5) days of the science of the suspension, from distinction provided for in article $1,037, \S 9$ to $\S 13$.

Although there are still issues related to the stay of pending proceedings, the measure may be able, in the medium and long term, to bring the improvement of civil justice, insofar as, despite an initial increase in the length of the claims, from a possible stay decision, after the decision of the repetitive case, with bind effect, each judge will follow or distinguish the specific case in relation to the repetitive judgment.

Moreover, after the judgment of the repetitive mechanisms by a Court, the judgment of repetitive cases will be faster, so that the Judiciary can concentrate on the judgment of non-repetitive issues.

\section{References}

Arruda Alvim, T. (2017). 'CPC abre debate sobre alcance de suspensão de ações em repetitivos', at https://www.conjur.com.br/2017-jun-11/teresa-alvim-cpc-abre-debatesuspensao-acoes-repetitivos 
Ballesteros, P.R. (coordinator) (2018). La gestión judicial de los nuevos tribunales civiles. Santiago, Chile: CEJA-JSCA.

Bueno, C.S. (2019). Manual de Direito Processual Civil. 4. ed. São Paulo: Saraiva.

Brazilian National Council of Justice at https://www.cnj.jus.br/pesquisas-judiciarias/jus ticaemnumeros/2016-10-21-13-13-04/pj-justica-em-numeros

Cabral, A. (2018). 'New trends and perspectives on case management: Proposals on contract procedure and case assignment management' in Peking University Law Journal 6(1):1:5-54, at https://doi.org/10.1080/20517483.2018.1603636

Cappelletti, M. (1975). 'La protection d'intérêts collectifs et de groupe dans le procès civil (Métamorphoses de la procédure civile)' in Revue internationale de droit compare, 27(3): 571-597.

Dusséaux, A. (2017). 'Best practice guide for managing Supreme Courts' at http://at.gov. lv/files/uploads/files/2_Par_Augstako_tiesu/Starptautiska_sadarbiba/BEST\%20PRA CTICE\%20GUIDE.pdf

Dynamic database of European judicial systems, at https://www.coe.int/en/web/cepej/dy namic-database-of-european-judicial-systems

Marinoni, L.G., Arenhart, S.C. \& D. Mitidiero (2016a). Comentários ao Código de Processo Civil. Vol. XV. São Paulo: RT,

Marinoni, L.G., Arenhart, S.C. \& D. Mitidiero (2016b). Comentários ao Código de Processo Civil. Vol. XVI. São Paulo: RT,

Mendes, A.G. (2017). Incidente de resolução de demandas repetitivas. Sistematização, análise e interpretação do novo instituto processual. Rio de Janeiro: Forense.

Odgers, R.G. \& C.F. Madurera (2019). Framing court system for case management: Chilean report, at https://ucsc-chile.academia.edu/RamonGarc\%C3\%ADaOdgers.

Schwarzer, W.W. \& A. Hirsch (2006). The Elements of Case Management: A Pocket Guide for Judges, $2^{\text {nd }}$ ed. Washington, D.C.: Federal Judicial Center.

Silva, P.E.A.da. (2010). Gerenciamento de Processos Judiciais. São Paulo: Saraiva.

Statistics and Reports, at https://www.uscourts.gov/statistics-reports/analysis-report

Uzelac, A. \& Van Rhee, C.H. (Remco) (eds.) (2008). 'Introduction' in Uzelac, A. \& Van Rhee, C.H. (Remco) (eds.) Civil Justice between Efficiency and Quality: From Ius Commune to the CEPEJ. Cambridge: Intersentia, pp. 1-2.

Uzelac, A. \& Van Rhee, C.H. (Remco) (eds.) (2018). 'The Metamorphoses of Civil Justice and Civil Procedure: The Challenges of New Paradigms-Unity and Diversity' in Uzelac, A. \& Van Rhee, C.H. (Remco) (eds.) Transformation of Civil Justice: Unity and Diversity. Cham, Switzerland: Springer, pp. 3-21. 


\title{
New Mechanisms for Recovering Budgetary Claims in Insolvency
}

\author{
By Lavinia-Olivia Iancu*
}

\begin{abstract}
The Emergency Ordinance No. 88/2018, on the amendment and supplement of several regulatory documents in the field of insolvency, was adopted in accordance with the objectives of the 2018-2202 Romanian Government program, which targets economic growth, the improvement of the business environment and the increase of the budgetary income collection level. Certainly, streamlining the insolvency procedures while consequently improving and protecting the creditors' rights should contribute substantially to the improvement of the business climate, creating the conditions for the rectification of viable businesses and a faster recovery of claims. However, an analysis of the amendments brought to the Insolvency Law leads to the conclusion that they do not target the creditors' protection in general, but focus strictly on the budgetary creditors. Although the idea of increasing the amounts collected to the state budget from insolvent companies is a coherent idea of any government, it often contradicts the principles that govern insolvency in Romania, rendering its practical implementation difficult, or even impossible.
\end{abstract}

Keywords: Insolvency; Budgetary claims; Principles.

\section{Introduction}

At the end of 2018, the Romanian Government determined ${ }^{1}$ that the insolvency regulations, Law No. $85 / 2014^{2}$, must be amended, as the recovery process of tax receivables from insolvent companies had to be streamlined in observance with one of the main aims of the insolvency process, that insolvent businesses have the opportunity to rectify themselves and recover.

The legislative amendment was intended to be implemented at the same time as the realisation of Romania's Governing Program for the 2018-2020, which included plans for economic growth and the improvement of the business environment, but also the increase of the tax receivables collection level. Within this context, by means of the Emergency Ordinance No. 88/2018 a series of amendments were brought to the insolvency regulations. Two of these amendments were considered to have a major impact, affecting the very principles of the insolvency procedure.

\footnotetext{
"Dr. of Law, Lecturer, Faculty of Economics, Tibiscus University of Timişoara, Romania. Email: relicons@yahoo.com.

${ }^{1}$ The substantiation note of the Government Emergency Ordinance (OUG) No. 88/2018 can be found on the Romanian Government website: http://gov.ro/ro/guvernul/procesul-legislativ/no te-de-fundamentare/nota-de-fundamentare-oug-nr-88-27-09-2018\&page $=14$

${ }^{2}$ Law no. 85/2014 for the Procedures of Preventing Insolvency is also known as the New Code of Insolvency. ${ }^{2}$
} 
With the justification of the desideratum to expand the tax receivables collection level within the insolvency procedure, the legal framework was created in order to activate the forced execution of the insolvency procedure and compel the debtor to submit an insolvency procedure initiation request when the tax receivables exceed $50 \%$ of the total value of the receivables. However, reinforcing the position of the budgetary creditor in the insolvency procedure, so as to require the debtors to respect the payments assumed for the budgetary claims, cannot lead to an unfair treatment of the other categories of creditors and must not violate the very established principles of the Insolvency Law.

\section{Insolvency Law in Romania}

The New Code of Insolvency establishes in Article 4 the fundamental principles guiding and regulating the entire procedure. The following principles are most relevant to the proposed analysis:

- Maximising the rate of asset selling and receivable recovery.

- Providing the debtors the opportunity to efficiently and effectively redress the business.

- Providing equal treatment of creditors with similar ranking.

- Acknowledging the existing rights of creditors and observing the priority order of receivables, based on a set of clearly determined and uniformly applicable rules.

The judicial doctrine ${ }^{3}$ was constant in outlining the features of the insolvency procedure: a judicial, collective, uniform and general procedure.

In recent years, the insolvency regulations have become a priority for the Romanian lawmaker, who constantly observed the correlation of the legal provisions with the economic reality in order to support the business environment. Naturally, the protection of the insolvent debtors is correlated with the protection of their creditor's rights.

Within the insolvency procedure, it is important to balance between the debtor's rights and the rights of their creditors. On the one hand, the legal regulation must allow the debtor to access the procedure with the first signs of financial imbalance and protect him for a certain period, within which he will have the opportunity to reorganise his business and pay both unsettled and current debts. From the standpoint of the creditor, who has to recover money within the insolvency procedure, this regulation allows the debtor's reorganisation only if the creditor's rights are protected. The very principles of the insolvency procedure guarantee equal treatment of creditors with similar ranking, acknowledge the creditors' rights and ensure the receivables' payment priority order based on clear rules.

${ }^{3}$ Bufan (2001) at 49-52; Deli-Diaconescu (2019) at 69. 


\section{Intervention}

Debtor's Interdiction to submit the Insolvency Procedure Initiation Request when the Tax Receivables Exceed 50\% of the Value of Receivables

Access to the insolvency procedure is available to any debtor in financial difficulty, whose debts are older than 60 days and amounting to no less than 40,000 Romanian Lei (approximately 8,700 euro).

Insolvency is defined as the asset state characterised by the insufficiency of available funds for the payment of certain, liquid and exigible debts. ${ }^{4}$ The debtor's insolvency is presumed when, after 60 days from the due date, the debtor has not paid his debt to the creditor. Insolvency is imminent when it is proven that the debtor will not pay the debts that he has accrued with the available funds on the due date. The threshold value $\mathrm{e}^{5}$ is the minimum amount of the receivables required so as to submit the insolvency procedure initiation request, 40,000 Romanian Lei, both for the creditor and for the debtor.

Article 1 para. 1 of Emergency Ordinance 88/2018 integrates the conditions that a debtor must fulfil when intending to submit the insolvency initiation request as follows: when the insolvency procedure initiation request is submitted by the debtor, the tax receivable quantum must be lower than $50 \%$ of the stated total of debtor's receivables.

This additional requirement, instituted as a mandatory condition for the debtor undergoing financial difficulties, contradicts the very purpose for which the insolvency law was amended, and the principles that guide the insolvency law.

Article 2 of Law No. 85/2014 clearly states the purpose of the insolvency procedure, i.e. instituting a collective insolvency procedure to cover the debtor's liabilities by providing, when possible, a chance for the redressal of his activity. The creation of a legal framework favourable to the reorganisation of a business going through difficulties has been a desideratum of the Romanian lawmaker since the adoption of Law No. 85/2014, when a series of legal amendments were made in order to encourage the debtor to get early access to the insolvency procedure and encourage a successful reorganisation. The amendment, brought by OUG 88/ 2018, seems to oppose this concept, favouring the tax creditor in an impermissible fashion.

According to the amendment, if a debtor's tax receivables exceed $50 \%$ of the total debts towards the tax creditor, the former will be prohibited from initiating the insolvency procedure and may be subject to forced execution. It is important to note that one of the main effects of initiating the insolvency procedure is the "automatic stay" granted to debtors, i.e. the rightful suspension of all judicial, extrajudicial actions or forced execution measures implemented in order to collect the receivables against the debtor's assets. Thus, it becomes obvious that in the absence of an "automatic stay" effect - specific to the insolvency procedure, the tax creditor's way to forced executions is open.

\footnotetext{
${ }^{4}$ Article 5 para. 29 of Law No. 85/2014.

${ }^{5}$ Ibid.
} 
To stress the importance that the Romanian lawmaker granted in 2014 to the early reorganisation concept, note the provisions of Article 66 para. 11 of Law No. 85/2014, which give the syndic judge the option to waive, in emergency cases, the temporary suspension of any procedure of forced execution of the debtor's assets before the settlement of the insolvency procedure initiation request. Thus, the debtor's protection from forced execution disappears in accordance with the current regulation if the debtor's receivables are greater than $50 \%$ of the total receivables towards the tax creditor.

Romanian law is not alone in this approach. European ${ }^{6}$ and other international ${ }^{7}$ judicial systems tend to facilitate the debtor's early access to the insolvency procedure, in a preventative manner, at the first signs of financial difficulty, when the business may be saved by reorganisation. All the international reference documents, such as the UNCITRAL Guide and the European Insolvency Regulation, promote the equal treatment of creditors with similar ranking and the prevention of the institution of exceptions for certain types of creditors, as the insolvency procedure is a collective one and the creditors must have the same judicial treatment.

This concept is particularly fundamental given that the debtor is perceived as a commercial partner, provider, services user, client, employer and tax payer, and his failure will have a negative impact on all the people and businesses he is interconnected with through his business.

In conclusion, it seems that the described amendment has a major negative impact, representing a step backwards on the path to modernisation of the insolvency law in Romania. In addition, it constitutes a treatment that favours the tax creditor in an unfair fashion, as compared to the other creditors participating in the insolvency procedure.

\section{Starting Forced Execution for the Collection of Current Tax Receivables}

The lawmaker created a special judicial procedure for receivables created during the insolvency procedure, also known as "current receivables": nonpayment thereof gives the creditor the right to demand the initiation of the bankruptcy procedure against the debtor.

Article 75 para. 4 of Law No. 85/2014 determines that the holder of a current, certain, liquid and exigible receivable that was recognised by the official receiver or in relation to which the latter omitted to issue a decision within 10 days from the submission of the payment request or recognised by the syndic judge, in cases where the receivable amount exceeds the threshold value, may request, during reorganisation period, the initiation of the debtor's bankruptcy procedure. This is relevant only in cases where such receivables are not paid within 60 days from the date on which the official receiver takes the measure of admission or omits to issue a decision on the payment request or of the law court decision.

\footnotetext{
${ }^{6}$ The UNCITRAL legislative Guide on the insolvency law issued in 2004

${ }^{7}$ The 848/2015 Regulation of the European Parliament and of the Council on the insolvency procedures; Proposal of Directive of the European Parliament and of the Council on the preventive restructuring frameworks, second chance and measures to increase the efficiency of restructuring, insolvency and discharge procedures and to amend Directive 2012/30/UES, Strasbourg, 22.11.2016.
} 
In addition, the amendment brought by OUG 88/2018 to Article 143 of Law No. 85/2014 states that forced execution may be initiated for debts accumulated within the insolvency procedure period, which are older than 60 days.

Thus, although the insolvency law had a sanction in place for debtors who accumulated current receivables within the procedure by not respecting the payment due dates, allowing the debtor to submit the bankruptcy request, the option of forced execution was added to the law.

This is not the first time that the Romanian legislation has attempted to introduce forced execution for current receivables. A similar amendment was the object of OUG 92/2013, yet its noncompliance with the constitution was acknowledged by Decision No. 447/2013 of the Constitutional Court of Romania.

In its report ${ }^{8}$ on the insolvency law in Romania, the World Bank stated that the elimination of the text of OUG 91/2013 is commendable; no exceptions may be allowed to enable some creditors to initiate the forced execution procedure, as such exceptions tend to reduce the debtor's reorganisation chances, violate the rights of other creditors participating in the insolvency procedure, and, most of all, violate the fundamental principle of insolvency - collectiveness and equitableness.

The conclusions of the World Bank are in full agreement with the Principles for an Efficient Insolvency promulgated by the World Bank in 2015, which in principle C5.2 establishes that once the insolvency procedure has been initiated, it is prohibited to dispose of the debtor's assets and all the actions taken by creditors in order to realise their rights on the debtors' assets must be suspended.

At present, Romania does have insolvency procedures where a significant amount of current receivables are not paid by the debtor, by increasing the amounts of money to be paid to the creditors in bankruptcy. However, the possibility of activating individual forced execution, as it is regulated at present, is incompatible with the insolvency procedure.

The insolvency procedure is a procedure of collective forced execution, ensuring that no creditor is allowed to act individually to recover receivables. As already shown, the main effect of the initiation of the insolvency procedure is an automatic stay, i.e. the interdiction for any creditor to enforce the receivable against the debtor's assets. Two of the fundamental features of the insolvency procedure, equal treatment and the collective nature of the insolvency procedure, are violated when certain creditors are allowed to carry out forced executions.

Allowing chaotic forced executions of the debtor's assets for the purpose of collecting current receivables may profoundly affect any of the debtor's attempts to reorganise the business or sell it. Thus it can cause a situation where creditors in the reorganisation procedure or the current creditors who do not hold an enforceable title will force the initiation of the bankruptcy procedure so as to prevent a current creditor the opportunity to initiate a forced execution and reduce or deplete the debtor's assets, which would considerably reduce the chances of recovering the receivables.

\footnotetext{
${ }^{8}$ Report on the observance of the standards and the codes of judicial regime of insolvency and of the creditors/debtors' rights, World Bank, April 2014 available on the World Bank website: https://www.worldbank.org/content/dam/Worldbank/document/eca/romania/rosc/Romania\%20 ICR\%20ROSC\%20Final-April\%202014\%20COMPLET_clean_ro.pdf
} 
On the other hand, we may not ignore any possible fraudulent attempts by the debtor to extract certain assets from the insolvency procedure at modest prices specific to forced execution, by making fraudulent agreements with their current creditors.

In other words, the current situation can and does result in a conflict between the collective insolvency procedure - insolvency based on clear rules and derogatory from the general jurisdiction - and individual insolvency procedures, which exist according to the general jurisdiction rules.

There does not seem to be any solution for the concrete fashion in which the judicial or tax executor must proceed, given that he is compelled to notify the creditors who benefit from bases of priority, whereas they suspended the right to forced execution as per Article 75 para. 1 of Law No. 85/2014. In the event that the judicial executor ignores such an imperative provision and allows the creditors involved in the insolvency procedure to participate in the forced execution as per the general jurisdiction, a new problem will arise regarding the distribution of the money obtained. The Insolvency Law, the Civil Procedure Code and the Tax Procedure Code contain different rules for the distribution of monies obtained from selling the debtor's assets. By further following the analysed hypothesis, we may presume that the execution will be challenged, an action which will not fall within the competence of the syndic judge, but will be settled before the tax litigation court or the court of general jurisdiction. Such courts will most probably not be aware of the insolvency procedure, the amounts of money collected by the creditors within the procedure and the list of creditors. All these elements are capable of deeply affecting the fragile balance that must be provided between the protection of the debtor's rights and the protection of the creditors' rights.

Forced execution does not only mean pursuing or selling assets that belong to the debtor, but also pursuing the amounts of money due to the debtor. The management of access and operation of the insolvency account is clearly regulated by the Insolvency Law, meaning that even if the debtor's administration right is not withdrawn, any payment requires the approval of the insolvency practitioner; if the debtor's administration right is withdrawn, all the payments shall be made solely by the insolvency practitioner. According to the provisions of Article 163 para. 3 of Law No. 85/2014, it is strictly prohibited to freeze the insolvency account: "the insolvency account may not be frozen by any criminal, civil or administrative measure disposed by the criminal investigation bodies, by the administrative bodies or by the courts of law."

Despite this, in such cases two contradictory measures may exist - on the one hand, it is possible to force the execution of the debtor's income for failure to pay current receivables by garnishment of the account, while, on the other hand, it is prohibited to freeze the insolvency account.

As long as the automatic stay principle is violated by establishing exceptions for a certain category of creditors, the insolvency foundation is affected in its inner elements, its mechanisms thus becoming completely non-functional. ${ }^{9}$

\footnotetext{
${ }^{9}$ Miloș \& Deli-Diaconescu (2018) at 8.
} 


\section{Practice "Corrects" the Legal Text}

As far as the initiation of the insolvency procedure is concerned, some accountants have found a way to circumvent the limitations put in place when the tax receivables exceed $50 \%$ of the total debts: the debtor who intends to open the insolvency procedure is instructed to submit an intentionally erroneous debt statement to the tax authority and request the initiation of the insolvency procedure based on these accounting documents. Once the insolvency procedure initiation decision has become final, the debtor will submit amended statements to the tax authority.

It is particularly difficult to check whether this device to avoid the legal restrictions has been put into practice. At present, there is no documentation indicating that decisions to open the insolvency procedure were cancelled based on the fact that the submitted accounting documents were falsified for the sole purpose of initiating the insolvency procedure.

Forced executions are a different matter. The tax creditor has already initiated these procedures by issuing enforceable titles, demands for payment and institutions of garnishments on the accounts opened within the insolvency procedure. In response, several legal alternatives have been attempted, all with the purpose of blocking the individual forced execution. Thus, it is possible to find in the recent jurisprudence challenges of the execution procedure, requests for annulment, requests for presiding judge orders and requests for suspension of the forced execution.

Although the existing practice in the matter of individual forced execution pursuant to Article 143 of Law 85/2014 has been relatively low as of the current date, jurisprudential opinions have already crystallised:

1. Forced execution may only be applied to procedures opened under Law No. 85/2014, not to procedures opened under Law No. 85/2006.

The Insolvency Law No. 85/2014 was published in the Official Journal of Romania No. 466 of June 25th 2018. At the same time, Law No. 85/2006 on the insolvency procedure was also abrogated, yet insolvency procedures initiated before this date are still subject to Law No. 85/2006. ${ }^{10}$ Thus, even at present the Romanian law courts have on their dockets insolvency procedures governed by Law 85/2006, while those opened before June 24, 2014 are governed by Law No. $85 / 2014$.

Some tax creditors initiated forced executions against the debtors who owed them current receivables without taking into account which Law, No. 85/2006 or Law No. 85/2014, applied to them. Decision No. 242/01.02.2019 of Pascani Court, for example, established that: "forced execution indicated in Article 143 para. 1 of Law No. 05/2014, as amended by OUG 88/2018, is only allowed in the insolvency proceedings initiated after October 2, 2018 according to Law No. 85/2014, and not according to Law No. 85/2006." A Civil Sentence No.

\footnotetext{
${ }^{10}$ Article 343 of Law No. 85/2014.
} 
415/13.05.2019 of the Salaj Court established that: "The reference by the tax creditor to the provisions of OUG No. 88/2018 may not be received in this case because it amends Law No. 85/2014 and not the old law No. 85/2006, so that the legislative amendments that allow the tax creditor to initiate the forced execution actions for current tax receivables at the same time as the collective procedure are not applicable in the cases which are judged according to the old law of insolvency and may not be opposed so as to antagonise the suspension of the forced execution measures provided by the law."

To the same end, Civil Sentence No. 2711/27.02.2019 of the Timisoara Court, determined that: "the insolvency procedure against the debtor claimant was opened according to Law No. 85/2006, which does not have similar provisions as the new Law of insolvency No. 85/2014. Since according to Article 343 of Law No. $85 / 2014$ the lawsuits were initiated before this law entered into force they remain subject to the law applicable before such date, therefore the legal provisions invoked in the statement of defence are not applicable to the case"

The syndic judge at the Civil Sentence No. 945/19.12.2018 of the Sebes Court considered that "the Insolvency procedure was initiated in relation to the claimant in accordance with Law No. 85/2006, therefore the provisions of Article $36^{11}$ are applicable, consequently the forced execution initiated by the respondent is subsequent to the initiation of the insolvency procedure against the debtor and has the same purpose as any other actions or measures of forced execution, and respectively it will be suspended as of right, as a natural consequence of the initiation of the insolvency procedure against the debtor."

Thus, a first important aspect clarified by the courts of law is that individual forced execution may not be initiated by the current creditors against debtors against whom the insolvency procedure regulated by Law No. 85/2006 was initiated, but only against debtors to whom Law No. 85/2014 applies, i.e. debtors in relation to whom the insolvency procedure was initiated before June 25, 2014.

\section{Forced execution applies only to the insolvency procedures opened starting on 2 nd October 2018 and which are in the reorganisation stage}

While forced execution may not be initiated against debtors to whom Law No. 85/2006 applies, in practice it is unclear whether all the debtors in relation to whom the initiation of the insolvency procedure was disposed according to Law $85 / 2014$ may be subjected to such measures. In order to examine this matter, following are a number of examples where OUG 88/2018 was applied to procedures initiated after its entry into force, October 2nd 2018, or OUG 88/2018 was applied to all the procedures initiated according to Law No. 85/2014.

In sentence No. 71/11.03.2019, the Dambovita Court established that: "the extension of the application of Article 143 of Law No. 85/2014 to the lawsuits initiated before OUG 88/2018 was entered into force is not permitted. Article 143 para. 1 of OUG 88/2018 finds its reason only in the case of lawsuits initiated

\footnotetext{
${ }^{11}$ Article 36 of Law No. 85/2006 states that starting from the date of initiation of the procedure, all judicial, extrajudicial actions or forced execution measures are suspended as of right for the collection of the receivables from the debtor or his assets
} 
before OUG 88/2018 was entered into force, while an exception from the rule of non-retroactive application of the law must be strictly specified, interpreted and applied."

The Medias Court, in Conclusion No. 607/18.04.2019, reached a similar conclusion: "As far as the fashion of recovery by the creditors of the debts accumulated after the initiation of the insolvency procedure, the court acknowledges that the general principle of non-retroactive application of the civil law applies, as stated in Article 6 of the Romanian Civil Code, while the new provisions will apply to the procedures initiated after the date of entry into force of the amending law, October 2, 2018. The claimant entered insolvency in accordance with Law No, 85.2014, a normative act containing a set of regulations that guide the activity of the company subjected to the procedure, and therefore must be characterised by clarity and predictability and essential amendments may not be accepted, such as the one introduced in Article 143 of Law No. 85/2014, which denatures the collective meaning of the procedure in its entirety and changes the entire meaning of the procedure in existence when the claimant entered insolvency. Hence, the court acknowledges that in relation to the current receivables appearing against the claimant after entering insolvency, for the recovery thereof, the creditors do not have at their disposal the option of individual forced execution."

The Pascani Court considered in Decision No. 242/01.02.2019 that: "forced execution is only allowed in insolvency proceedings (calculated from the date of registration of the procedure initiation request) initiated as of October 2, 2018".

As may be concluded from the aforementioned examples, it seems that the new regulation, which allows individual forced execution, is significantly restricted in scope, and, more precisely, refers strictly to debtors whose insolvency was opened after October 2, 2018.

In the absence of a clear legal text, the jurisprudence intervention was required in order to establish the legal scope of application of individual forced execution in insolvency cases.

3. The requests referring to the forced executions initiated in accordance with Article 143 para. 1 of Law No. 85/2014 fall within the competence of the syndic judge

Once the law was in place, various requests were submitted for the annulment or suspension of forced execution measures to various courts: the general jurisdiction court when the Civil Procedure Code provisions were targeted, and the court specialising in administrative-tax litigation when the execution was carried out based on enforceable titles issued by the tax creditor or the court specialising in insolvency procedure.

In cases where the exception for lack of material jurisdiction of the syndic judge was invoked, decisions were handed down clarifying which court holds material jurisdiction so as to judge the actions based upon Article 143 para. 1 of Law No. 85/2014.

According to Civil Decision No. 42/R/23.01.2019 of the Court of Appeal of Brasov, "the rules established by the Civil Procedure Code on the jurisdiction of 
the execution court are not applicable considering the special character of the provisions of Law No. 85/2014." To the same end, Sentence No. 59/27.02.2019 of the Dambovita Court also stated that: "the acceptance of the material jurisdiction of resolution in favour of the execution court would lead to a severe impact on the collective and equitable nature of the insolvency procedure inasmuch as the protection granted to the debtor from the date of initiation of the insolvency procedure is also granted to all the creditors in competition, with respect to a possible bias or preferential treatment of one of them to the detriment of all the others."

In Sentence No. 145/14.05.2019, the Caras Severin Court also rejected the exception of lack of material jurisdiction of the syndic judge, although Article 714 and Article 615 of the Civil Procedure Code, referring to the appeal against the enforcement of execution, both establish that the district court as execution court has the jurisdiction to settle these type of cases. In the abovementioned matter, the forced execution was initiated by a tax creditor according to Article 143 para. 1 of Law No. 85/2014, representing the attempt of a creditor to individually recover the receivables after the date of initiation of the insolvency procedure of the debtor. Thus, the legality of the measures taken by this creditor from the standpoint of the Insolvency Law was unclear. Consequently, the jurisdiction of settlement belongs to the syndic judge.

\section{No garnishment may be imposed on the unique insolvency account}

Even though it is clear that OUG 88/2018 applies strictly to the insolvency procedures opened after October 2, 2018, it is still important to clarify how these forced executions will be carried out.

The simplest method of recovering current receivables for the tax creditor is the imposition of garnishment on the account. Yet any company in the insolvency procedure may carry out its collection and payment operations through a single account, entitled "the insolvency account", which is overseen by the insolvency practitioner, i.e. all the payments are made with his approval.

As already indicated, according to the provisions of Article 163 para. 3 of Law No. 85/2014, it is strictly prohibited to freeze the insolvency account: "the insolvency account may not be frozen by any criminal, civil or administrative measure disposed by the criminal investigation bodies, by the administrative bodies or by the courts of law." Nonetheless, the tax creditor may impose garnishments on the insolvency accounts of the debtors, while the courts may cancel such forced execution measures.

According to Decision No. 47/07.02.2019, the Commercial Court of Mures established that: "In the absence of a suspension of the measure of imposition of garnishment on the insolvency collection account, the debtor company may no longer make any payments, neither for current receivables resulting from current commercial relations occurring during the performance of the reorganisation plan confirmed by the creditors, nor for the receivables registered in the payment schedule of the confirmed reorganisation plan, which would create imminent 
damage both to the debtor company and to its creditors by the company failing to achieve its reorganisation plan and going bankrupt."

A much more elaborate justification, supporting the prohibition of freezing the insolvency account, can be found in the Civil Sentence No. 1/03.01.2019, pronounced by the Salaj Court: "The insolvency procedure is itself an executional procedure with strict applicability rules, so that the concrete fashion in which the forced execution of the tax creditor will be carried out must be detailed, given that the conditions under which the text of Article 163 para. 3 of Law No. 85/2014 were not amended, and it therefore completely prohibits any measure of freezing the debtor's insolvency account." From this point of view, it is impossible to approve a garnishment of the insolvent debtor's available funds and the current creditor has yet to activate other forms of forced execution other than the garnishment, such as the personal and real forced execution of the debtor's assets or the forced execution of third parties from which the debtor is to receive amounts of money. Even these latter modalities of forced execution must be carried out in accordance with the specific instructions of the insolvency procedure, under the conditions where the same assets or income may be assigned to bases of priority in favour of pre-existing creditors. Creditors registered to the list of creditors having previous receivables must comply with a de jure suspension on their right to request the forced execution on the insolvent debtor's assets.

Close scrutiny of the first wave of practice in the six months prior to the activation of OUG $88 / 2018$, shows that the jurisprudence had a decisive role in diminishing the visibly negative effects of the legal provisions which allow the current creditor in the insolvency procedure to initiate the individual forced execution. Forced execution is allowed only with respect to the debtors who entered insolvency after November 2, 2018, and the legal control of the application of the forced execution measures falls within the material jurisdiction of the syndic judge who manages the insolvency procedure. In addition, the account containing the debtor's assets may not be garnished.

What, therefore, can the current creditor enforce from the insolvent debtor's assets? Without identifying the doctrine or the jurisprudence in the matter of personal (with the exception of garnishment) or real individual forced execution in insolvency, it seems that forced execution will only be permissible regarding the personal/real assets which do not have a basis of priority, are not necessary for the performance of the current activity of the debtor and are not essential for a successful reorganisation. If a tax creditor takes such aspects, which are not legislatively established, into account, in theory the creditor could carry out an individual forced execution for the recovery of current receivables. However, for such forced execution not to hinder the performance of the insolvency procedure, there must be a suitable collaboration between the insolvency practitioner and the judicial executor. 


\section{Conclusion}

Before the amendment of the Insolvency Law by OUG 88/2018, the legal text granted a series of advantages to the budgetary creditor in general, but, above all, to the tax creditor. Thus, the tax creditor is informed about the insolvency procedure initiation request submitted by the debtor, as the proof of notification to the tax body with respect to the debtor's intention to enter insolvency is a mandatory document for the admissibility of the debtor's request. However, it is important to note that all the creditors have a time limit, established by the syndic judge, for the submission of the statements of receivables in relation to the debts preceding the initiation of the insolvency procedure. The tax creditor is exempt from this limit, and may submit by waiver a supplement of receivables following a tax inspection carried out within sixty days from the date upon which the Insolvency Procedures Bulletin published the notification referring to the initiation of the insolvency procedure.

Even if the aforementioned provisions, existing in the insolvency law, established a special system for the tax creditor, they were not received as an "unequitable treatment with respect to the other creditors participating in the insolvency procedure". This is because the large workload of such creditors was taken into account and, once informed of the debtor's intention to open the insolvency procedure, creditors were assigned a generous time limit for the performance of the tax inspection, as compared to the remaining creditors.

OUG 88/2018 is considered a step backwards in the matter of insolvency, as it prevents the debtors from accessing the procedure if a percentage greater than $50 \%$ of the total debts are budgetary, but, above all, allows the current creditor to initiate an individual forced execution within the framework of a collective forced execution.

The declared purpose of OUG 88/2018 may not be reached by provisions which, at a first glance, tend to determine an increase of the recoveries of budgetary receivables within the insolvency procedure. Yet, after a deep analysis, it is clear that these provisions affect the very concept of insolvency, by protecting the debtor going through financial difficulty and granting him a chance of redressal.

The simple introduction of a legal text allowing the activation of individual forced execution by the current creditor is of such that it confuses the collective insolvency procedure. If the lawmaker maintains its idea to allow individual forced executions within a collective procedure, it will have to regulate the concrete modality of performance thereof. As already indicated, the correction of an ambiguous and interpretable legal text was made by jurisprudence, but this is not the norm. The intention of jurisprudence to stop a "problematic" legal text from affecting the performance of an insolvency procedure is welcome, but this is not the role of law courts.

In my opinion, the introduction of an individual forced execution within a collective forced execution will raise difficulties which the lawmaker is not prepared to answer, while the responsibility for finding balance between the 
protection of the debtor's rights and the protection of the creditors' rights lies entirely with the court of law.

There are no solutions for this situation. If we accept that by introducing a single sentence into the legal text, stating that "for the debts accumulated within the insolvency procedure period which are older than 60 days, forced execution may be initiated", the principles promulgated in the matter of insolvency were violated, compromising the purpose of the insolvency procedure which grants the debtor a chance of reorganisation, the this sentence must be eliminated. If the lawmaker intends to allow the option of individual forced execution by the current creditors in the insolvency procedure, it must be regulated in detail, starting from the scope of application, material jurisdiction, measures of forced execution that may be taken, and categories of assets that may be subjected to forced execution. All these aspects that must be taken into account by the judicial executor, so as not to damage the adequate performance of the insolvency procedure.

The insolvency law in Romania was commended at a European level for its modernism and for the fact that it corresponded to the European principles that stress the reorganisation opportunity given to the debtor, "the second chance" and the equal and equitable treatment of the creditors within the insolvency procedure. The " 3 rows of legal text" introduced by OUG 88/2018 have deprived it of this characterisation, and therefore an urgent intervention of the Romanian lawmaker is required.

\section{References}

Bufan, R. (2001). Reorganizarea judiciară și falimentul. București: Ed. Lumina Lex.

Deli-Diaconescu, A. (2019). Problema de compatibilitate dintre procedura insolvenței și Codul de procedură civilă. București: Ed. Universul Juridic.

Miloş, S.M. \& A. Deli-Diaconscu (2018). 'Analiza aspectelor de noutate aduse de OUG nr. 88/2018 la Codul insolvenței', in Revista de insolvență Phoenix nr. 66 octombriedecembrie 2018. București: Ed. Universul Juridic. 



\title{
A Case Study of State and Law in the Interwar Period: The Three Historic Criminal Trials of Bishop of Paphos Leontios during the British Rule in Cyprus $(1932,1938,1939)$
}

\author{
By Harry Stamelos*
}

\begin{abstract}
In 1932, 1938 and 1939 three criminal trials of Bishop of Paphos Leontios took place in Cyprus. There were not just three trials. There were the outcomes of a wide movement of Greek Cypriots against the British Rule. At first, we shortly refer to the 4.000 years history of Cyprus, the biographical elements of Bishop Leontios with a short notice on the three trials, and in detail the historic and political context of the Interwar Period in Cyprus. Then, we will analyse the three historical criminal trials of Bishop of Paphos Leontios.
\end{abstract}

Keywords: British Cyprus; Interwar Period; Bishop Leontios; Criminal trials

\section{Introduction: Cyprus from $2^{\text {nd }}$ Millennium BC to the $21^{\text {st }}$ Century}

Cyprus is an island country in the Eastern Mediterranean located south of Turkey, west of Lebanon, northwest of Israel, north of Egypt, and southeast of Greece.

Cyprus was settled by Mycenaean Greeks in two waves in the 2nd millennium BC who established twelve Ancient Cypriot Kingdoms ${ }^{1}$ after the Trojan War. Cypriot Kings paid taxes to the heads of the empires of the Assyrians, Egyptians and Persians, from whom the island was seized in 323 BC by Alexander the Great. Subsequent rule by Ptolemaic Egypt, the Classical and Eastern Roman Empire (30 BC-323), the Byzantine Empire (324-1191), the French Lusignan dynasty (1192-1489) and the Venetians (1489-1571), was followed by over three centuries of Ottoman rule between 1571 and 1878 (de jure until 1914).

Cyprus was placed under the UK's administration based on the Cyprus Convention in 1878 (Berlin, June 4) and was formally annexed by the UK in 1914 (as a British Protectorate) and unilaterally annexed military occupation (19141922). From 1922 to 1960 Cyprus was a British Crown Colony. While Turkish Cypriots made up $18 \%$ of the population, the majority Greek Cypriot population and its Greek Orthodox Church had been pursuing Union with Greece (called 'Enosis'), which became a Greek national policy in the 1930s, 1940s, and 1950s. Following riots and armed revolutionary acts of the Greek Cypriots in the 1950s (under the Cypriot Organization called 'EOKA'), Cyprus was granted indepen-

*LL.B., LL.M. (EU law), LL.M. (History of the Law), PhD Scientific Collaborator, School of Law, European University Cyprus, Engomi, Nicosia, Cyprus. E-mail: charalamposstamelos@ gmail.com. ${ }^{1}$ Stamelos (2019) at 121. 
dence in 1960. On 15 July 1974, a coup d'état was staged by Greek Cypriot nationalists and elements of the Greek military junta in an attempt at Enosis, the incorporation of Cyprus into Greece. This action precipitated the Turkish invasion of Cyprus on 20 July 1974, which led to the illegal invasion and illegal capture of the present-day territory of Northern Cyprus in the following month, after a ceasefire collapsed, and the displacement of over 150,000 Greek Cypriots and 50,000 Turkish Cypriots. A separate Turkish Cypriot state in the north was illegally established by unilateral declaration in 1983; the move was condemned by the international community, with Turkey alone recognizing the new state. These events and the resulting political situation are matters of a continuing dispute.

The Republic of Cyprus has de jure sovereignty over the entire island, including its territorial waters and exclusive economic zone, with the exception of the UK Sovereign Base Areas of Akrotiri and Dhekelia, which remain today under the UK's control according to the London and Zürich Agreements. However, the Republic of Cyprus is de facto partitioned into two main parts: the area under the effective control of the Republic, located in the south and west, and comprising about $59 \%$ of the island's area; and the north, administered by the self-declared illegal and not recognized Turkish Republic of Northern Cyprus, covering about $36 \%$ of the island's area. Another nearly $4 \%$ of the island's area is covered by the UN buffer zone. The international community considers the northern part of the island as territory of the Republic of Cyprus occupied by Turkish forces. The occupation is viewed as illegal under international law, amounting to illegal occupation of EU territory since Cyprus became a member of the European Union.

The Republic of Cyprus has been a member of the Commonwealth since 1961 and joined the European Union on 1 May 2004. On 1 January 2008, the Republic of Cyprus joined the Eurozone.

\section{Bishop of Paphos Leontios (1896-1947) and a Short Introduction on His Three Trials}

Before we examine the historic facts of the era of the three criminal trials of Bishop Leontios $^{2}(1932,1938$, and 1939) and the specific data of the trials, we should first mention the biographical data of Leontios in order to reveal his background and a short notice on his three criminal trials.

Leontios $^{3}$ was born in Limassol in 1896. At the age of 17, he became a monk and at the age of 23, he was ordained a Cypriot Greek Orthodox Deacon in Limassol. He went to Athens, studied at the Theological School of the National and Kapodistrian University, and received his degree in Theology at the age of 27.

\footnotetext{
${ }^{2}$ Bishop Leontios was Locum Tenens for the Archbishop's Throne/See (Acting Archbishop). We refer equally to Bishop Leontios or Locum Tenens or defendant or Acting Archbishop hereinafter. ${ }^{3}$ Leontios, who full name was Leontios Savvas, was Bishop of Paphos in Cyprus from 1930 to 1947. One should not mix him with another Bishop Leontios, who was the Bishop of Neapolis in Cyprus at the first half of the seventh century. See. Hadjichristodoulou (2004).
} 
He then returned to Cyprus where he was appointed Professor of Theology at the Pancyprian Christian Cypriot Greek Orthodox Theological School (Seminary) in Larnaca, while he was a Preacher in Church Area called 'Metropolis' of Paphos.

In 1927 he continued his studies in the USA at the Theological Academy in New York, where he received his master's degree in Theology.

In 1930, while still in the USA, he was elected Bishop of Paphos at the age of 34 and, returned to Cyprus, where he was ordained Presbyter in Nicosia and took office as Bishop of Paphos thereafter.

Leontios represented Cyprus in important theological Conventions in Lambeth in 1930, in London in 1931 and in Bonn in the same year.

When the Greek Cypriot riots against the Britons broke out in October 1931, Leontios was out of Cyprus. Following those riots, the British colonial government with difficulty and after much hesitation finally allowed Leontios to return to Cyprus.

Upon the death of Archbishop Kyrillos of Cyprus on 16 November 1933, Leontios became the Locum Tenens (Acting Archbishop) of the Archiepiscopal See, whilst on 13 September 1933 he had already become an Acting Bishop of the Church Area 'Metropolis' of Kition due to the death of the exiled Bishop Kition Nicodemos Mylona.

In November 1941 Bishop Leontios led the Cyprus mission in Athens and in London. Five years later, in 1946, at the age of 50, he moved to London, at the age of 50 years, where he called for the Union of Cyprus with Greece ('Enosis'). The British government denied Leontios any chance for the Union of Cyprus with Greece ${ }^{4}$.

Bishop Leontios was elected Archbishop of Cyprus on 20 June 1947. On 16 July 1947, he addressed the Greek Cypriots and was asked to abstain from the Consultative Assembly convened by the Government.

Bishop Leontios died on 26 July 1947, at the age of 51 years, thirty-seven days after he had been elected as Archbishop. There were rumours that his death was not of natural causes, but the true cause of death was never investigated.

Before becoming Archbishop of Cyprus, Bishop Leontios had been prosecuted and sentenced three times for acts that the British colonial government considered to have created the possibility of 'disfavour' against the UK King and the Local government (1932), and the public peace (1938 and 1939). Leontios indeed made a strong effort to prevent government intervention in the ecclesiastical issues of Cyprus and his tireless stance resulted in the abolition, after post-war, of the laws of 1937 concerning the election of an Archbishop.

Bishop of Paphos Leontios, an advocate ('Enosist' ${ }^{5}$ ) of the Union of Cyprus with Greece ('Enosis'), was tried during the British domination by the British courts in Cyprus in 1932, in 1938 and in 1939.

Initially, in 1932, pursuant to the Defence for Certain Possessions Order, he was tried for a breach of peace and was ordered to pay 250 British Pounds as a warranty, whilst he was not ordered to mandatorily stay in Paphos, in the sense of his compulsory residence in Paphos, as later.

${ }^{4}$ Pafitou (2010) under Sec. 1946.

${ }^{5}$ Ioannides (2019) at 230. 
In 1938, pursuant to Law 30/1935 provisions, Leontios was ordered by the court to mandatorily reside in Paphos.

In 1939 (May 15), pursuant to Law 30/1935, Deputy Marshal Ashmore who was the Prosecutor, accused Bishop of Paphos Leontios as follows, asking for his trial before the appropriate Court ${ }^{6}$ :

'The police officer submitted an application on behalf of the police and requested a court order to be issued against Leontios Sava, Bishop of Paphos who is an English national. An affidavit is issued and attached a bulletin containing the actions and behaviour of the accused'.

The position among the clergy of the accused and his past, as his words and phrases referred to in the attached bulletin, bring out the purpose of Bishop of Paphos, which is to breach of the peace ${ }^{7}$ and also to corrupt the youth ${ }^{8}$.

Article 2 of Law 30/1935 prohibited the breach of the peace or the possibility that a person could cause the breach of the peace (this was left to the discretion of the judge to decide on whether there was such a possibility), whilst article 15 provided for the penalty of mandatory residence in a specific city or town by a court order.

It was the era of 'Palmerocracy' (1933-1939), when there was lack of freedom in Paphos and in Cyprus in general. The constitutional (civil) rights were an unknown notion, and any voice raised, either as protest or as contrary to the British Rule in Cyprus, was concerned not only as disturbing but also as an illegal act that was being prosecuted criminal proceedings. ${ }^{9}$.

However, in British Cyprus of the Interwar Period and the era of 'Palmerocracy' there were no civil rights or freedoms.

\section{The Historic, Political and Legal Framework of the World War I, the Interwar Period, and the Era of Leontios' Trials (1914-1939)}

The historic facts from 1914 to 1939 in short were the following.

\footnotetext{
${ }^{6}$ Machlouzaridis (1979) at 68.

${ }^{7}$ In England, Wales and Northern Ireland, breach of the peace is descended from the Justices of the Peace Act 1361 which refers to riotous and barratous behaviour that disturbs the peace of the King. Modern English authority defines a breach of the peace as 'when a person reasonably believes harm will be caused, or is likely to be caused, to a person or in his presence to his property, or a person is in fear of being harmed through an assault, affray, riot, unlawful assembly, or some other form of disturbance' ( $R$ v Howell (1982) QB 416).

${ }^{8}$ These accusations ('breach of the peace', 'youth corruption') remind us of the ancient Greek criminal case of Socrates who was tried in 399 BC and was then accused of 'youth corruption'. Stamelos (2018) at 81-101.

${ }^{9}$ In the USA, for example, the US Supreme Court based on the First Amendment to the US Constitution held in 1965 that a state government cannot employ "breach of the peace statutes against protesters engaging in peaceable demonstrations that may potentially incite violence. Therefore, it held that such laws were unconstitutional violating the individual right to protest Cox v. Louisiana, 379 US 536 (1965). Though the facts were similar in both cases the British Cyprus court found the Bishop guilty in 1930 while the US Supreme Courts acquitted Cox.
} 
The British government formally annexed the Mediterranean island of Cyprus, which had been a British protectorate since 1878, on November 5, 1914. The leaders of the Turkish Cypriot community on the island of Cyprus declared their loyalty to Britain during the First World War. Sir John Eugene Clauson was appointed as British High Commissioner on January 8, 1915. Archbishop Kyrillos II died on July 19, 1916, and Bishop Kyrillos was elected Archbishop of Cyprus as Kyrillos III on November 11, 1916. British High Commissioner Sir John Eugene Clauson died on December 31, 1915, and Sir Malcolm Stevenson was appointed as Acting High Commissioner.

Greek Cypriots convened an assembly on October 10, 1921, demanding the union of Cyprus with Greece (Enosis). Cyprus was proclaimed a British crown colony on March 10, 1925. Sir Malcolm Stevenson was appointed British Governor on the island of Cyprus on March 10, 1925.

Sir Ronald Storrs was appointed as British Governor on the island of Cyprus on November 30, 1926. Elections for the Legislative Council were held in October 1925. On November 28, 1929, British Colonial Secretary Lord Passfield rejected demands that Cyprus be unified with Greece. Elections for the Legislative Council were held in 1930.

\section{Cyprus in 1931}

As a result of grievances with the British colonial government, several Turkish Cypriots convened "a national congress (Milli Kongre) in the town of Söz on May $1,1931 " 10$. In response to the national congress, the British colonial government stated that 'it had come to the attention of the government that some people belonging to the Islamic community had gathered in the form of an assembly, which they call the National Congress, and that they elected a person among themselves as mufti' and that the election of a mufti was against 'the law, the traditions and the precedents, and thus it would on no condition be recognized by the government'.

Beginning on October 17, 1931, the Greek Cypriot members of the Legislative Council, including Bishop Nicodemus Mylonas, resigned in protest of the enactment of a tariff law (import duties) by the British colonial government. The National Radical Union of Cyprus (Ethnike Rizospastike Enosis KypriakìEREK) was established on October 18, 1931.

Bishop Nicodemus Mylonas called for 'disobedience and insubordination to the illegal laws of this immoral, vile, and shameful regime' during a speech in Lemesos (Limassol) on October 20, 1931.

Greek Cypriots rioted against the British colonial government throughout the island of Cyprus beginning on October 21, 1931.

Governor Storrs declared martial law on October $21,1931^{11}$.

\footnotetext{
${ }^{10}$ Rappas (2008) at 362-363. This chapter "Cyprus in 1931" is mainly based on Rappas (2008) and his references.

${ }^{11}$ For the Education System of the British Administration from 1878 to 1931 see Heraclidou (2017) at 7-36.
} 
The rebellion was suppressed by British security forces on October 27, 1931, resulting in the deaths of six Greek Cypriots.

The British colonial government abolished the Legislative Council and banned political parties. Several Greek Cypriot leaders, including George Hajipavlou, Dionysios Kykkotis, Theofanis Tsangarides, Theofanis Theodotou, and Theodoris Kolokassidis, were deported to Britain and Gibraltar on November 3-6, 1931.

In 1931, an uprising of Greek Cypriots proclaiming 'Enosis' (political union of Cyprus with Greece) dominated the island of Cyprus, then a British colony. Rapidly recovering from the initial shock, British authorities seized the opportunity to abolish representative institutions (long considered an impediment to the sound administration of the island) and impose limitations on freedom of expression. Under Governor Sir Richmond Palmer, an era of authoritarian rule began. The broader aim of British rule in the 1930s was to reshape Cyprus as an ideal polity, whose inhabitants would thrive materially and civically; however, the two preconditions for the establishment of such a polity-the neutralization of local politics and the international isolation of the island-would be rendered unattainable owing to the activity of Greek Cypriot notables who seized the opportunity of a vacancy in the Throne of the Orthodox Archbishop of Cyprus to restructure a political arena with international ramifications ${ }^{12}$.

A little after midnight, on 22 October 1931, all that was left of Government House in the capital city of Nicosia, Cyprus was a smouldering pile of rubble. Some hours earlier, a procession of approximately five thousand Greek Cypriots, mostly young male students, but also priests and notables, had marched from Nicosia, shouting for Enosis (union with Greece) and the end of British colonial rule. After a siege of nearly three and a half hours and heavy stone-throwing, the crowd managed to set fire to the colonial governor's residence before the police dispersed them. The event, which occurred in a context of heightened political frustration and economic hardship, sounded the alarm of an island-wide revolt, with Greek Cypriots of different social origins and ages raiding public offices, stripping them of symbols of British authority and substituting, where possible, the Greek flag for the Union Jack ${ }^{13}$.

The 1931 revolt, or Oktovriana ('events of October') as it was later called, constituted, in the words of Robert Holland, the 'most humiliating blow sustained by the British in any of their Crown Colonies in the years between the two World Wars' (1998, 4-5). The Governor, Sir Ronald Storrs, whose career was permanently stained by this incident, had to appeal to the British military headquarters in Egypt for help in crushing the uprising. By early November, law and order prevailed throughout the island, at the price of seven Cypriots killed, thirty wounded, ten deported for life, and 2,606 convictions resulting in fines and prison terms for sedition. Repression was swift and thorough, and all Cypriots, including the large community of Turkish-Cypriots who had not taken part in the revolt, were stripped of both their liberal rights and representative institutions

\footnotetext{
${ }^{12}$ Rappas (2008) at 363.

${ }^{13} \mathrm{CO} 67 / 240 / 13,1931$.
} 
which had been gradually granted when the island, after three hundred years of Ottoman rule, became a British dependency in 1878.

The elected Legislative Council, founded in November 1882, was abolished; municipal elections were suspended; and village authorities, hitherto elected, were to be directly appointed by the governor ${ }^{14}$. Advocating Enosis was declared illegal and flying foreign flags were forbidden; assemblies of more than five persons, without the prior authorization of colonial authorities, were prohibited ${ }^{15}$; and censorship severely curtailed the freedom of newspapers to discuss 'matters of public policy or general interest ${ }^{, 16}$.

Year 1931 marked a radical turn in relations between Cypriots, especially Greek Cypriots, and British colonial authorities in the continuation of the Great Depression $^{17}$.

It was a traumatic experience for the actors of the time and it became a foundational myth for future administrations in Cyprus, as both the spectre of professional infamy and a blank check for the implementation of new policies. Prior to the uprising, the bubbling activity of Greek Cypriot prelates, members of the Legislative Council, and editors of newspapers promoting the cause of Enosis, had been viewed by colonial authorities with either bemused contempt or, when they believed it impaired the efficient administration of the Island, the orderly discharge of their duties, or even their prestige, with irritation. In a well-known passage in his memoirs, Governor Storrs wrote that the Legislative Council 'proved an exasperating and humiliating nuisance'.

After 1931, this passive, but confident derision gave way to a more alarmist vision of politics, what Ranajit Guha has called a 'prose of counterinsurgency' (1996), which had serious implications for the decision-making process of the colonial administration and its policies. Impressions of a rather folklorist genre on the identity of the Cypriots and academic debates questioning the island's links with Greece and Turkey had hitherto been very much confined to personal writings, travellers' accounts, private correspondence, or memoirs of retired officials" ". "In the wake of the uprising, these impressions flooded official documents as the identity Cypriots claimed for themselves, and the way they conceived their relations to the space they inhabited, became the keystone of official colonial policy ${ }^{19}$.

The period between 1931 and the beginning of World War II has been called Palmerokratia (Palmerocracy) ${ }^{20}$, a derogatory term coined by Cypriots after the

\footnotetext{
${ }^{14} \mathrm{CO} 67 / 242 / 8,1931$.

${ }^{15}$ The Cyprus Gazette 1932, at 743-745.

${ }^{16}$ Rappas (2008) at 363.

${ }^{17}$ The Great Depression started in 1929 in the US and lasted until the late 1930s in many countries in the world. Alecou (2016) at 11: 'In Cyprus, collapse of agricultural products' prices in the early 1930s led to the bankruptcy of export companies in Larnaca, the General Motors dealership and textile mills in Nicosia and Paphos.'

${ }^{18}$ Rappas (2008) at 363-364.

${ }^{19}$ Rappas (2008) at 364.

${ }^{20}$ For the British Atmosphere in Cyprus 1931-1935 see Heraclidou (2017) at 37-56.
} 
name of Governor Sir Herbert Richmond Palmer (1933-1939) as "a metonym for the most authoritarian phase of British rule on Cyprus, both preceding and exceeding Palmer's own mandate" 21 .

Sir Reginald Edwards Stubbs was appointed British Governor on the island of Cyprus on October 20, 1932.

\section{Cyprus in 1933-1939}

Sir Herbert Richmond Palmer was appointed British Governor on the Island of Cyprus on November 8, 1933 (till 1939). Archbishop Kyrillos III died on November 16, 1933 and after twenty seven years Cyprus formally achieved its independence from Britain on August 16, 1960. Let us examine in detail the historic, political and legal framework from 1933 to 1939.

Sir Herbert Richmond Palmer assumed his governorship on the 21st of December 1933, at the age of $56^{22}$.

A lawyer by training, he had spent most of his colonial career in the Northern Provinces of Nigeria (1904-1930) where he reached the position of Lieutenant Governor (1923) before assuming the governorship of Gambia in $1929^{23}$.

Surprisingly, very little research has been conducted on Cyprus in the 1930s, and thus scholars are (quite wrongly) left with the impression that nothing of consequence happened in the Interwar Period and in specific between 1931 and World War II, and that the repressive measures enacted in the wake of the Oktovriana left the country in a state of political and social torpor.

The regime in Cyprus during this time did not confine itself to denying Cypriots the means to claim publicly national identities or debate government policy.

The ambitions of successive Governors went much further and repression was considered 'merely' as a necessary step for laying the foundations of a polity purified from what they perceived as 'petty politics'. They dreamt of instilling, in the words of Governor Stubbs, 'public spirit' in the minds of Cypriots ${ }^{24}$ and providing them with a 'civic education', in the words of his successor Palmer ${ }^{25}$.

These aims were definitely envisaged by colonial administrators as a constructive counterpoint to the repressive measures currently in force; they gave meaning, even a cause, to their work and were certainly intended to legitimize colonial rule both locally and abroad. As such, they need to be taken into account to get a fuller understanding of the nature of Palmerocracy.

Another problem with portraying Palmerocracy as a 'black authoritarian decade' is that it obscures the sophisticated ways Cypriots were able to circumvent

\footnotetext{
${ }^{21}$ Georghallides (1981-1982) at 277.

${ }^{22}$ The Cyprus Civil List, 1934, 6. Rappas (2008) at 363-365. This chapter "Cyprus in 1933-1939" is mainly based on Rappas (2008) and his references.

${ }^{23}$ The Colonial Office List, 1935, 747.

${ }^{24} \mathrm{CO} 67 / 254 / 4,1933$. CO abbreviates 'Colonial Office, Cyprus Original Correspondence, National Archives, London'. WO abbreviates 'War Office, Registered Files, National Archives, London'.

${ }^{25} \mathrm{CO} 67 / 264 / 10,1936$.
} 
censorship and surveillance and establish 'niches' within which political activity could re-emerge and function ${ }^{26}$. Despite the use of Palmerocracy to describe it, the regime was shaped gradually over a period dating from both before and during the Palmer regime.

Scrutiny of three official documents published in the early 1930s, along with the circumstances responsible for their conception and their intended use, suggest that colonial authorities distanced themselves from the relative inertia that characterized the first years of British rule in Cyprus and sought to penetrate local society and shape it into an ideal polity. To account for all the instances of Cypriot opposition to colonial rule, individual and collective, would be impossible, so only one such instance is explored here-the vexing question of the archiepiscopal elections from 1933 onwards.

During Palmer's governorship, part of the Greek Cypriot elite transformed the Church into a niche where political activity could re-emerge with the goal of denying the political ambitions of the colonizer ${ }^{27}$.

Three major texts provided the general framework of policymaking in Cyprus during the 1930s: The Survey of Rural Life in Cyprus (1930) by Brewster Joseph Surridge, District Commissioner of Larnaca; Sir Reginald Edward Stubbs's Memorandum (1933); and Sir Ralph Oakden's Report on the Finances and Economic Resources of Cyprus (1935) ${ }^{28}$.

Each one of these documents was designed for its own purpose in its own specific context, but under the rule of Governor Palmer they became the administration's primary references, often both inspiring and informing specific policies.

Surridge's Survey provided the social, Stubbs's Memorandum the political, and Oakden's Report the economic and financial backdrop against which official policies were decided and implemented.

The Survey of Rural Life in Cyprus was the product of extensive socioeconomic research over a two-year period, coordinated by Surridge who mobilized close to 30 investigators-government officials, retired officials, lawyers, and merchants.

They were sent to 569 of the island's 641 villages to interview the people. The resulting document is much more than a mere compilation of statistics and figures; indeed, it can be characterized as the first comprehensive ethnographic survey of the island ${ }^{29}$.

Its predominant concern was the grim conditions in which the overwhelming majority of the island's population lived; most were small-proprietor peasants, crippled with debts. $82 \%$ of the island's 59,175 peasant-proprietors owed money, either to urban merchants, lawyers, or thriving farmers. Consequently, Surridge strongly advocated for the development of cooperatives and cooperative credit

\footnotetext{
${ }^{26}$ Ioannou (1948).

${ }^{27}$ Rappas (2008) at 365.

${ }^{28}$ Rappas (2014) at 25

${ }^{29}$ Rappas (2008) at 365; Surridge (1930) at 7, 78-90.
} 
societies as well as for a reform of the agricultural bank in order to bolster the cultivators' financial (and political) autonomy ${ }^{30}$.

The Survey of Rural Life in Cyprus depicts a lively, integrated, and cohesive image of Cypriot society which contrasted with the dry, factual, and disjointed reports which district commissioners and other officials regularly sent to the colonial secretary's office or the headquarters of their departments.

By contrast, Oakden's Report on the Finances and Economic Resources of Cyprus deals more extensively with the colonial administration rather than local society.

Oakden, a retired Indian Civil Service official and former Senior Member of the Board of Revenue (Lucknow), was appointed Financial Commissioner for Cyprus by the Secretary of State for the Colonies in March 1934. He spent a little over four months on the island, visiting the headquarters of administrative and technical departments (secretariat, health, agriculture, police, education, forestry, etc.) as well as rural areas, where he met the peasantry and members of cooperative societies $^{31}$.

The Financial Commission's duty was twofold: to suggest ways to curb the colonial administration's expenditures and to propose the most cost-effective government-sponsored financial, legislative, and institutional incentives to stimulate the local economy. The document produced by Oakden at the term of his mission, signalled a clear intention to bolster the government's 'initiative in the matter of development,' opening an era of increased state interventionism, particularly in the domain of agriculture. This contrasted starkly with the limited measures the Cyprus government had hitherto taken, mainly through frequently unenforceable laws.

Unsurprisingly, Surridge's Survey of Rural Life in Cyprus is specifically mentioned by Oakden in his own Report, in which he proposed the appointment of 'special extra-legal Courts or Committees' to investigate cases of rural indebtedness and impose arbitration between creditors and debtors. He further suggested the transformation of the existing Agricultural Bank into a state bank as a part of the colonial administration's treasury department and its disentanglement from the cooperative credit societies ${ }^{32}$.

The Memorandum by Stubbs was intended for internal circulation only and is of an entirely different nature. Written on 16 October 1933, it is a review of Cyprus's constitutional situation following the abolition of the Legislative Council in 1931. The Memorandum is founded on a radical mistrust of Cypriots. 'I know of no community which is so utterly unfit to take any responsible part in the Government of its native country as is that of Cyprus', Stubbs wrote. Cypriots would have to go through a 'considerable period of training in western civilization' before any kind of representative government could be reintroduced.

An essential starting point for this training was the reform of secondary education 'by the introduction of an English atmosphere'. "The second objective of the administration in Cyprus should be to 'take steps to crush the bad leaders of

\footnotetext{
${ }^{30}$ Rappas (2008) at 365-366; Surridge (1930) at 36, 37, 45-46, 47-50.

${ }^{31}$ Rappas (2008) at 365-366; Sir Oakden (1935) at 5.

${ }^{32}$ Sir Oakden (1935) at 113, 58.
} 
people', of which Stubbs distinguished two 'species', the Communists and the Greek-Orthodox Church"33.

Stubbs was confident that the penal laws enacted since the beginning of his governorship in December 1932 would suppress altogether the former. The Church's activism on behalf of Enosis on the other hand, constituted a more serious threat. Stubbs felt that the immediate concern of the colonial administration should be to put an end to the interference in politics of an institution depicted as thoroughly corrupt, which derived power from its extensive land holdings. Within this newly defined authoritarian regime, the only possibility of Cypriot participation in the official policy that Stubbs envisioned was through the establishment of an Advisory Council composed of official and unofficial Cypriot members, all 'nominated by the Governor and approved by the King'. Beyond his recommended policies, Stubbs also set the tone by which Cyprus was thenceforth to be ruled, what may be called the discursive framework of the regime; he introduced new, or simply ossified old, colonial categories, distinguishing between the 'respectable' or 'better-class Cypriots' as opposed to self-serving 'demagogues'. He further reintroduced and gave official credence to a representation of Cypriots as 'Orientals' or 'Asiatics' which served only to buttress the perception of their alleged political inaptitude.

Unsurprisingly, the term 'Greek' was to be banned from official corresponddence when referring to Greek Cypriots, favouring instead the clumsy categories of 'Non-Mohammedans' or 'Orthodox-Christians, ${ }^{34}$.

In their efforts to devise a framework for the new regime, these three documents, drafted in the first half of the 1930s, illustrate a much more interventionist drive on the part of colonial authorities. They show a determination to penetrate the local society and understand its inner workings. At the same time, however, they contributed to the sanctioning and reification of the representation of Cyprus as a peasant society exploited by self-serving and politically-minded usurers.

In spite of this, the three surveys constituted the blueprints for new experimentations in the creation of an ideal polity in a decade when Europe was brimming with ideas about social engineering. In this respect, the failed uprising of 1931 had indeed been a 'godsend' for colonial authorities.

It had been roundly and publicly condemned by Greece's Prime Minister, Eleftherios Venizelos, in the name of his country's friendship with Britain, and this condemnation seemed to guarantee, officially at least, Greece's noninterference in Cypriot politics. Moreover, it had allowed colonial authorities to abolish representative institutions considered major impediments to the sound administration of the Island ${ }^{35}$.

The ground was seemingly clear for the colonial administration, under the governorship of Palmer, to undertake a thorough reformation of Cypriot society.

\footnotetext{
${ }^{33}$ Rappas (2008), 366.

${ }^{34} \mathrm{CO} 67 / 254 / 4,1933$.

${ }^{35}$ Rappas (2008) at 367. The author refers to others sources and authors, such as Markides, Georghallides, and Richter.
} 
To shape his policies in Cyprus, Palmer relied heavily on the three official texts discussed above. He asked officially for the dispatch of a Financial Commission at the beginning of his governorship in early 1934 and subsequently assigned Surridge the duty of writing a critical view of Oakden's yet-unpublished report $^{36}$. (Palmer's administration carved a policy along three complementary axes: the reorganization of the colonial administration in terms of decentralization, the development of agriculture, and the reform of education.

Perhaps nothing illustrates better the new governor's eagerness to break with pre-1931 administrative practices than his systematic insistence (very much in line with Stubbs's suggestions) on the need to avoid the prompt restoration of any representative institutions and even of the elective principle.

This was consistent with legislation enacted in the wake of the 1931 revolt as successive revisions of the Cyprus Criminal Code made political activity a criminal offense. 'Political agitators' were often viewed as being on par with 'criminals' and labelled as such in official reports ${ }^{37}$.

Moreover, their activities were monitored by the police's criminal investigation department ${ }^{38}$. Elective politics in Cyprus, according to Palmer and some of his correspondents at the Colonial Office, amounted to 'professional Levantine politicians ${ }^{39}$ promoting their own vested interests through 'bribery ${ }^{40}$ under the guise of (manufactured) 'popular demand" 41 .

The abolition of elections in Cyprus, whether at a central (Legislative Council) or local (Municipal Councils and Village Commissions) level, went hand-in-hand with censorship of the press. Their intent was to drive influential Cypriots (often those closely linked to, or even owners of, widely-read newspapers) away from the public stage. 'In the Near East,' wrote Palmer, 'freedom of the press means suppression of free speech or at least honest free speech: it puts a premium on corruption, intimidation and fraud ${ }^{, 42}$.

\section{English Laws 36/1935, 30/1935 and 26/1936 in Cyprus}

Under Law 36 of 1935, which provided for an overhaul of the entire judicial department and a significant decrease in its permanent staff, the Governor assumed the right to appoint, suspend, or remove the presidents and judges of the district courts, a prerogative heretofore reserved for the King-In-Council ${ }^{43}$.

Moreover, under Law 30 of 1935, executive officers obtained the right to intern or even commit to prison for a term up to one year 'any person [. . . upon a

\footnotetext{
${ }^{36} \mathrm{CO} 67 / 255 / 1,1934$.

${ }^{37} \mathrm{CO} 67 / 277 / 15,1937$.

${ }^{38}$ WO 32/2405 1934. See also Rappas (2008) at 367.

${ }^{39} \mathrm{CO} 67 / 264 / 10,1936$.

${ }^{40} \mathrm{CO} 67 / 256 / 7,1934$.

${ }^{41} \mathrm{CO} 67 / 284 / 1,1938$.

${ }^{42}$ CO 67/274/6, 1937. See also Rappas (2008) at 367-368.

${ }^{43} \mathrm{CO}$ 67/269/14, 1935.
} 
statement on oath being made that such person is likely to commit a breach of the peace, 44 .

Finally, Law 26 of 1936 handed jurisdiction to the district commissioners for the settlement of certain petty criminal offenses ${ }^{45}$.

Laws enacted in 1932, 1933, and $1934^{46}$ "postponed municipal elections for one year, while Law 16 of 1934 extended the period to five years" ${ }^{\text {"4 }}$. Palmer preventively brushed aside any possible criticism concerning the lack of representation under such a system by stating that 'government itself cannot nominate as Mayor or Muktar any man who cannot reasonably be expected to function satisfactorily and has some support ${ }^{48}$. In fact, the mayors of the Island's six major towns-Nicosia, Limassol, Larnaca, Famagusta, Kyrenia, and Paphos-had all been elected prior to the 1931 revolt and their mandate was consequently merely extended by the aforementioned laws. Moreover, the powers of municipal councils were considerably enhanced, and assumed a police character as mayors had the power to grant or revoke licenses and permits to coffee shops, those incontrovertible places of sociability and vectors of politicization in Cypriot life, or to require hotels 'to keep a special register with the names of every person staying together with other particulars as may be prescribed ${ }^{39}$. The success of decentralization in its triple ambition-to facilitate cooperation between government and society, to secure a more efficient control of the country by pre-empting the formation of any centralized political movement, and to 'educate and train' the Cypriots to be ' $\operatorname{good}$ citizens ${ }^{50}$ depended on two closely intertwined prerequisites: the material and social improvement of the Cypriots' lives and the thorough reform of schools and the educational system.

This double correlation was clearly established by Palmer, who in 1938 stated that he wanted to wait another ten years before reintroducing the elective principle at the local level; namely, 'a period by which the boys and girls now at school would have grown up, and the present method of administration would possibly have matured and produced further results in greater well-being and economic prosperity ${ }^{51}$. With regard to education, the administration's most immediate concern was to put an end to the dissemination of nationalist ideas in Cypriot schools, both Greek and Turkish. According to a 1932 report of the Director of the Education Department, the curriculum of Greek Cypriot and Turkish-Cypriot schools was exactly that devised by the Ministries of Public Instruction of Greece and Turkey respectively; likewise, 'the whole internal organization of these schools-books, timetable, examinations, etc.-was arranged in accordance with

\footnotetext{
${ }^{44} \mathrm{CO} 67 / 269 / 14,1935$.

${ }^{45}$ Rappas (2008) at 368. Rappas refers to the newspaper of that time 'Eleftheria' which in Greek means 'Liberty'.

${ }^{46} \mathrm{CO} 67 / 256 / 7$, 1934, Rappas (2008) at 368-369. Rappas refers to the newspaper 'Eleftheria', the Cyprus Gazette 1932, 101, 102 (Official) and to Greek Cypriot author Aimilianides.

${ }^{47} \mathrm{CO} 67 / 256 / 7,1934$.

${ }^{48} \mathrm{CO} 67 / 264 / 10,1936$, Rappas (2008) at 369.

${ }^{49} \mathrm{CO} 67 / 284 / 1,1938$.

${ }^{50} \mathrm{CO} 67 / 264 / 10,1936$, Rappas (2008) at 370.

${ }^{51}$ CO 67/284/1, 1938.
} 
instructions and circulars' from these ministries ${ }^{52}$. In 1933, the Cyprus government enacted a law making the governor 'the central authority for all matters relating to elementary education'. It gave him the power to control, approve, or veto 'the books to be used in schools and school libraries; the classification, examination, registration and promotion of teachers . . . the curriculum, syllabus, and courses of instruction to be followed in schools, ${ }^{53}$.

\section{Education Reforms by the British in Cyprus (1935-1939)}

In March 1935, Arthur Mayhew, Joint Secretary to the Advisory Committee on Education at the Colonial Office, was sent to Cyprus to discuss with the governor the means for carrying out reform of the secondary education. The report he produced in early April of that year recommended five main courses:

a) The government would cease to assist financially institutions which depended on 'alien governments' (i.e., Greece and Turkey) for their functioning;

b) The funds thus liberated would partially be allocated to the English school, which was to be transformed into a training institution for future Cypriot colonial civil servants;

c) Special attention should be given to the education of girls because, as the report read, 'politically the home influence of women cannot be overlooked';

d) 'The question of suitable Greek and Turkish reading books ought now to be taken up without further delay'; and

e) Mayhew, concurring with Oakden's own conclusions, recommended that the government 'experiment[ed] with one or two Rural Middle Schools, intended essentially for future small landholders and aiming generally at the improvement of village life ${ }^{, 54}$.

\section{Church of Cyprus, Bishop Leontios and the relations with the British in Cyprus (1935-1939)}

When Leontios Savva, Bishop of Paphos and Locum Tenens (Acting Archbishop) of the Archiepiscopal See, protested against Law 25 (CO 67/260/3 1935e), a principal secretary at the Colonial Office commented:

The Acting Archbishop is naturally perturbed by our new educational policy. The object of that policy is to strike at the root of the political ideas which he represents [enosis]. The influence of the Church on education

\footnotetext{
${ }^{52} \mathrm{CO} 67 / 246 / 13,1932$, Rappas (2008) at 370.

${ }^{53} \mathrm{CO} 67 / 249 / 13,1933$.

${ }^{54}$ Sir Oakden (1935) at 79-84. CO 67/259/15, 1935. For the end of Palmerocracy and the British Educational Policy in Cyprus from 1936 to 1939 see Heraclidou (2017) at 57-68.
} 
has been a powerful lever in its hand.... The issue is between Western ideas and enlightenment and the reactionary obscurantism of a corrupt hierarchy ${ }^{55}$.

Relations between the Autocephalous Greek Orthodox Church of Cyprus and the colonial authorities had been brittle from the very beginning of British rule in 1878. Specifically, British authorities remained steadfastly opposed to any intervention of the Church in temporal affairs; thus, from the outset, they distanced themselves from the millet system that prevailed during the Ottoman administration (1571-1878) under which the Archbishop served as Ethnarch (leader of the Nation) and Orthodox prelates were granted wide temporal powers over their followers.

From late 1933 onwards, under Palmerocracy, this complicated relationship would be further strained by the vexing question of the election of the Archbishop of Cyprus.

Archbishop of Cyprus, Kyrillos III, died of pleurisy on 16 November 1933 at the age of $74^{56}$.

Immediately, the Bishop of Paphos, Leontios Savva, assumed the position of Locum Tenens (Acting Archbishop) of the Archiepiscopal Throne, pending the election of a permanent successor to Kyrillos. At the time, the Greek Orthodox Church of Cyprus was in an awkward position.

Two of the island's three Bishops-Makarios of Kyrenia and Nicodemos of Kition-had been deported in the wake of the uprising of October 1931 due to the British regime's perception of them as ringleaders of the Enosis movement ${ }^{57}$.

In these circumstances, the holding of the Holy Synod in Cyprus was rendered all the more problematic since the colonial administration systematically refused to authorize the exiles' return. In response, the exiled bishops and the Locum Tenens decided to postpone the elections until these 'non-canonical restrictions' were lifted ${ }^{58}$.

From the colonial government's point of view, the question of the filling of the Archiepiscopal Throne stretched far beyond a simple ecclesiastical matter. Thus Governor Stubbs would remind the Colonial Office, just a few weeks after the Archbishop's decease, that the bishops 'and their supporters within and without the Church desire[d] their return [...] in order that they may continue their political activities and pursue (with renewed authority, were one of them to be elected Archbishop) their work of sedition' ${ }^{59}$. The 'Archiepiscopal Question' was deemed to be politically freighted as it was likely to pull out of the shadows personalities deemed dangerously evasive since, as religious leaders, they constantly blurred the boundaries between the realms of the sacred and the secular

\footnotetext{
${ }^{55}$ CO 67/249/13, 1933, Rappas (2008) at 371.

${ }^{56}$ Rappas (2008) at 371 refers to the newspaper "Phoni tis Kyprou, 1933" which in Greek means "Voice of Cyprus".

${ }^{57}$ Rappas (2008) at 371.

${ }^{58}$ Rappas (2008) at 371-372 refers to newspapers of that time, "Phoni tis Kyprou", "Chronos", which in Greek means "Time" and also to Apostolos Barnabas of 1935.

${ }^{59} \mathrm{CO} 67 / 252 / 13,1933, \mathrm{CO} 67 / 252 / 13,1933$, Rappas (2008) at 372.
} 
and persisted in impinging upon the latter. In Cyprus after 1931, however, the colonial administration's priority was order, and this redefined 'reason of state' called for a clear-cut allocation of roles; specifically, as Palmer would put it, 'we should make it very plain that there will be no more 'Ethnarchy' or politics so far as we can help, ${ }^{60}$.

In contradistinction to this position, the Locum Tenens appealed to a different level of legitimacy. The practical impossibility of holding an election was attributed to the fact that, though exiled, Makarios and Nicodemos remained, from the standpoint of the Orthodox Church of Cyprus's regime, rightful bishops. As such, they maintained their full rights, both 'synod' and 'pastoral,' guaranteed by the 'Ecclesiastical Law of the Eastern Orthodox Church,' namely the resolutions of the seven Ecumenical Councils applying to all Eastern Orthodox Churches. If elections were not held 'canonically,' they would amount to a denial of the Church's divine legitimacy and thus deprive it of its 'influence on the life of its flock $^{, 61}$.

In other words, the order of legitimacy to which the Locum Tenens appealed was at once de-territorialized (it applied to all Eastern Orthodox Churches), timeless (it was rooted in the venerable resolutions of the seven Ecumenical Councils), and immaterial (or divine). This legitimacy was in contrast to the 'state decree,' which was territorial (confined to the colony of Cyprus), circumstantial (linked to one event, the 1931 uprising), and material (i.e., human-made and thus revocable $)^{62}$.

Meanwhile, in Cyprus, resistance to the Cyprus government's policy took a new turn and gathered momentum as the Church appeared strengthened and legitimized in its struggle. Closely watched by the colonial state, the Locum Tenens multiplied his tours and speeches around the island, attracting increasingly larger crowds whose public displays of allegiance encouraged him $^{63}$.

The confrontation between the Church and the colonial authorities culminated in 1939, when the government brought charges against the Locum Tenens, leading to his conviction ${ }^{64}$.

\section{The Three Criminal Trials of Bishop of Paphos Leontios $(1932,1938,1939)$}

In 1932, Leontios, then Bishop of Paphos, had been convicted for breach of peace sedition by the Limassol Assize Court, because of his public criticism of those who had testified against Greek Cypriots in the aftermath of the 1931 revolt.

In April 1938, the Locum Tenens, Acting Archbishop Leontios was again prosecuted for delivering seditious speeches, and was found guilty of seeking to

\footnotetext{
${ }^{60} \mathrm{CO}$ 67/262/18, 1935, Rappas (2008) at 372.

${ }^{61}$ Rappas (2008) at 372 refers to the newspaper "Phoni tis Kyprou" and also to Meyendorff of 1979.

${ }^{62}$ Rappas (2008) at 372-373.

${ }^{63} \mathrm{CO} 67 / 251 / 12,1938$, Rappas (2008) at 372-373.

${ }^{64}$ Kalantzopoulos (2015) at 82. For the end of Palmerocracy and the British Educational Policy in Cyprus from 1936 to 1939 see Heraclidou (2017) at 57-68.
} 
disturb the tranquillity of the colony. He was placed under police supervision for one year, ordered to mandatorily reside in the municipal limits of Paphos, and forbidden to leave the district without written authority of the police, under the 1935 Prevention of Crime Law.

Exactly a year later, in April 1939, based on information given by an informant, a party of fourteen policemen raided the Archbishopric looking for guns and seditious documents. This raid, which took place on Orthodox Easter Monday, as well as the fact that the priests were body-searched and the sacristy opened, caused an outcry. Bishop Leontios protested to the Governor that the search at the Archbishopric was not only a violation of the immunity of the Church (thus, an impious act), but also contrary to the promise given by the first British High Commissioner back in 1878 that the Government would respect the rights of the Church.

Bishop Leontios forwarded his complaints to the Secretary of State, and sent letters to the Ecumenical Patriarch, the Patriarchs of Jerusalem, Alexandria, Antioch, Romania and Serbia, the Archbishop of Athens, the Heads of the Autocephalous Churches of Georgia, Albania and Poland and, of course, the Archbishop of Canterbury. The raid on the Archbishopric was intensely criticized by the Colonial Office, as it brought only negligible results, while eliciting severe criticism from the Anglican Archbishop and considerable local reaction ${ }^{65}$.

A few weeks later in May 1939, Bishop Leontios was summoned to the District Court of Limassol for what was to turn into a three-day trial (15-17 May) that would again lead to his conviction. Leontios' alleged subversive activity from mid-1938 to mid-1939 led to accusations of disturbance of the peace in the colony, and actions against British sovereignty over the island.

Leontios was further accused of corrupting the minds of schoolboys, claiming to represent the Cypriot people and delivering sermons and speeches of political nature - that is, claiming Ethnarchy.

What is of particular interest is that these accusations did not take the form of charges against Bishop Leontios, but constituted grounds for determining the 'general circumstances' of the case, and for proving his 'known character' and the 'likelihood of disturbing the public tranquillity' to the Court.

The 1935 Prevention of Crime Law, under which Leontios was convicted, allowed the police to summon and then arrest an individual deemed likely to breach the peace, without the obligation to prove that they were guilty of any particular act that showed such intent.

As the President of the Court, Justice Thomas Wilkinson, noted at the opening of the trial, 'there could be no strict evidence that a person is likely to do something. What is likely to happen must be a matter of opinion'.

On the final day of the trial, explaining his argumentation for making an order, he stated:

I do not have to decide, and I do not decide, whether the Respondent has committed any offence. The Prevention of Crime Law [...] is not penal, $[\ldots]$ it is $[\ldots]$ preventive: what I have to decide is whether or not an Order is to be made - and one

${ }^{65}$ Kalantzopoulos (2015) at 83. 
of the considerations I have to bear in mind is, the likelihood [...] of any disturbance of the public tranquillity - not whether any such disturbance has taken place. I have to look to what may happen in the future than make any ruling as to what has happened in the past ${ }^{66}$.

\section{The First Trial of Bishop of Paphos Leontios (1932)}

In 1932, Leontios was tried for the first time by the British authorities in Cyprus. The amendment to the Penal Code did not leave much room for 'national' action. However, soon the Bishop began preaching, which, according to the British authorities, aimed to preserve the unionist movement, thus being called by the Governor of Paphos R. Browne in his office.

Leontios writes about the meeting:

The commander from my handwriting said that I might ignore that circumstances have been exchanged and that the penal law has been denied and that propaganda is forbidden. That government knows that in my sermons I try to keep this feeling lively, despite the people and that I want to hold on to the torch of the Union.

The Bishop said he was sure that he did not infringe the new Penal Code, since he did not refer to the Union, nor did he attack England. At the same time he stressed that he was doing his duty as a bishop against his flock and that if he wanted the government to displace him he was able to do so.

Despite close police surveillance, Leontios continued his anti-British speeches. Thus, in early November 1932 he was led to the court, accused of 'interinsurgency speech'. The extensive indictment drafted by the colonial authorities included eight categories, related to speeches by the Bishop in the previous two months in three villages and at the Paphos estate, where he used phrases that were likely to cause 'dissatisfaction whether or disfavour between the nationals of a. Majesty or the inhabitants of the colony'. In fact, the accusation that was burdening Leontios was that he had sharply criticized the pulpit of those Greek Cypriots who had given testimony against their fellow villagers-specifically in Pissouri village riots against the British in the Limassol district-for participation in October 1931 riots. At the same time he praised the sentenced persons and held a memorial for the dead of the rebellion, he called them saints and martyrs of the nation.

The trial began on 14 November 1932 at the Criminal Court of Limassol.

President of the Court was Court of Appeal Justice Tomas, along with two judges, Justice Green, President of the District Court of Limassol and Justice Halet. Public Prosecutor was W. B. Blackall, defendant's advocates were Ant. Triantafyllides, I. Klerides, K. Tornaritis, T. Michaelides, E. Ieropoulos, and the translator was Bairamian.

Leontios acknowledged all the accusations, but explained that he criticized only those from personal motives who gave false testimony against their fellow villagers and denied that he intended to cause anti-government actions.

\footnotetext{
${ }^{66}$ Kalantzopoulos (2015) at 84.
} 
He testified that he understood 'now' that such preaching (sermons) were a violation of the law of the country, which he was obliged to obey.

In a new statement to the court, Bishop Leontios undertook the obligation not to make sedition in the future, giving the opportunity to advocate General W. B. Blackall to emphasize that any speech related to the Union was considered sedition.

The advocate of defendant $\mathrm{A}$. Triantafyllides requested that the judgment be postponed, with the obligation on the part of the defendant to be presented to the Court, whenever he would be called.

Finally, on the second day of the trial, Leontios submitted his statement.

By that statement by Bishop Leontios, he promised to the Court and he was bound not to make speeches or sermons which could possibly cause 'displeasing against the government of Cyprus or among the inhabitants of the island or to publish a change in the sovereignty of Cyprus.'

The Court accepted the statement of Bishop Leontios and ordered him to pay 250 British Pounds for a period of three years as a warranty (bail) for not repeating the same offences ${ }^{67}$.

The outcome of the trial and the declaration of Leontios particularly satisfied the British Authorities who saw the accusing Bishop suffering a loss in his prestige and reputation (albeit temporarily).

\section{The Second Trial of Bishop of Paphos Leontios (1938)}

In 1938 Leontios was tried for the second time by the British authorities in Cyprus. Six years later, after his first trial, Leontios, as the Locum Tenens (Acting Archbishop), was brought to the courts for the second time.

In particular, in April 1938, Bishop Leontios was summoned to appear before the district Court of Limassol, pursuant to aforementioned Law 30 of 1935 'on the Prevention of Crimes', after police information for his speeches in various temples, which were judged that they were likely to breach the peace, causing interferences with public order and security.

The trial was held on Holy Wednesday, April 20, 1938, causing great interest, as noted by the newspaper 'Eleftheria', which described the process extensively. Public Prosecutor duties performed by the Deputy Chief of police Officer Ashmore (Prosecutor Ashmore), who pointed out that the police complaint was submitted 'to put an end to the subversive propaganda and ensure the serenity to the territorial'. As stated in the summons, for sixteen months the defendant publicly supported the change of the English regime.

Reading the indictment at the beginning of the trial before the Court, Prosecutor Ashmore cited the various controversial speeches and sermons of Bishop Leontios, even his prayers, in which the Greek King George II was quoted as 'Our King' ${ }^{68}$. As Prosecutor Ashmore argued, after the enactment of the

\footnotetext{
${ }^{67}$ Papageorgiou (2008) ar 471-480.

${ }^{68}$ Ibid.
} 
Ecclesiastical Laws of $1937^{69}$, the defendant 'broke the campaign to humiliate the government of the colony' and ended up stressing:

Cyprus is a British Colony and will remain so.

Our King is George VI and no one another, no British citizen is subject to any other King except the one, King George VI.

This must be understood by all in Cyprus and the subversive propaganda of the accused must stop immediately.'

Consequently, Prosecutor Ashmore called for the issuance of a Court Order, which would have placed the Bishop of Paphos Leontios under police supervision for one year, as well as the identification (restriction) of the municipal boundaries of Paphos and the non-movement without police permission.

Bishop Leontios admitted the charges and the President of the Court concluded that the words and phrases used by Bishop Leontios 'could influence the ignorant and illiterate people', accepted the statement of Prosecutor Ashmore, and the President of the Court ordered that Bishop Leontios should be in police custody and also ordered the defendant Bishop Leontios to mandatorily reside in Paphos.

As Governor Palmer informed the Minister of the Colonies, according to reports from the provincial governors, the condemnation of Bishop Leontios was acceptable to the population as a logical and inevitable measure, while the public was indifferent to the hierarch and his action (apparently, the opposite was the case, public opinion was interested in Leontios and followed every step of his and every sermon). For his part, the exiled Bishop Makarios continued the surveyor for his dignified stance in court-considering, moreover, that the trial stimulated and raised the national morale of the people-but noting that with this legal prosecution was given valuable Argument to the colonial government to justify its policy on the archdiocesan issue that beset the Church of Cyprus from 1933.

This and the Greek side constituted to Leontios through the Kyrenia to abstain 'all provocation' towards the government.

The trial of Leontios caused the discomfort of the Anglican archbishop, who asked through the Bishop of Thyation Germanos the mediation of the Ecumenical Patriarch to indicate to the surveyor the damage that his action caused to the issue of Archbishop elections.

\section{The Third Trial of Bishop of Paphos Leontios (1939)}

In 1939, Leontios was tried for the third time by the British authorities in Cyprus.

\footnotetext{
${ }^{69}$ These government laws related to the election of an Archbishop, and reversed the current normal order and constituted interference in the internal affairs of the Church of Cyprus, as they ruled out the candidacy of certain persons for the See and the governor's approval of the person elected. For the Autocephalous of the Church of Cyprus and its legal status, see Stamelos (2018) at 220-224.
} 
The Commissioner of Larnaca, the first official to propose the enactment of the law, argued that it would allow the government to control subversive activity and restrict the freedom of movement of suspect individuals.

In fact, the law was introduced, as we explain above, because the emergency Defence Regulations that had been enacted after the 1931 revolt to prevent political agitation would have to be eventually repealed. The debate that accompanied the amendment of the law in 1931, as well as the relevant discussions for the introduction of the new Peace and Order (Preservation) Law, make clear that the goal of the authorities was to repress 'the expression of political opinions' by criminalizing 'utterances, publications or conduct [...] likely to disturb public tranquillity or [...] prejudicial to good government'.

The law seems to have been modelled on the Palestine Prevention of Crime Ordinance of 1933, which had amended a 1929 Ordinance for the Prevention of Crime, and shared a similar objective with the Cypriot legislation. The most controversial provision of the Palestine Law was the barring of the public and representatives of the Press from judicial proceedings under the Ordinance, which indicated that the expected trials would not deal solely with ordinary civil crime. The repressive character of the law was made clearly manifest in the trial of the Locum Tenens, four years after its enactment. According to the provisions of the Cyprus 1935 Prevention of Crime Law, a Commissioner or a President of a district court could act against an individual, upon information that they were likely to breach the peace.

The accused was required to prove that their intentions were peaceful, or the judge could order that the person post bond or be restrained within the limits of a district, town or village. Moreover, the law stated that the prosecution was not required to prove that a person committed any particular act in court, or even intent of purpose. A case could be made simply based on circumstantial evidence or even the 'known character' of the accused. On a first level, the law introduced the criminalization of intent. As stated in sections 2 and 5(4b), it was not the criminal act itself that was prosecuted, but the likelihood of its being committed.

Although similar provisions had been introduced into the United Kingdom's legal system as early as 1871, and its logic had been partially maintained in the 1908 Prevention of Crime Act, the political dimensions of their application in Cyprus institutionalized the suppression of freedom of expression, especially in relation to nationalist and anti-colonial positions.

At a second level, the provisions concerning the evidence that would determine the guilt or innocence of the accused were clearly arbitrary.

The 'circumstances of the case' and the 'known character' of the accused were seen as sufficient for a person's conviction, and were at the absolute discretion of the Court. Although similar provision had been present in the 1824 Vagrancy Act, the 1871 Prevention of Crimes Act (section 15), and the 1908 Prevention of Crime Act (section 10) ${ }^{70}$, in Cyprus, the law also provided the Governor and commissioners with the ability to exercise judicial powers. And

\footnotetext{
${ }^{70}$ Section 15 of the 1871 Prevention of Crimes Act and section 10 of the 1908 Law, which replaced it, provided that reputation, character and circumstances were to be considered as evidence in a criminal trial. Kalantzopoulos (2015) at 85.
} 
taking into consideration the pro-rogation of the Legislative Council after the 1931 revolt and the permanent ability of the government to legislate with Orders in Council, the law represented the final blow for the separation of powers on the island. This feature made the law all the more advantageous in the eyes of the government and the Colonial Office. Similar legislation had existed in other colonies and dependencies, such as Palestine, Kenya, Ireland and the Channel Islands $^{71}$.

As Governor Palmer stated, [T]he Law [...] has been enacted as an exceptional measure in terrorem maleficorum and for the preservation of the security of the law-abiding citizen. By associating members of the Administration and judicial officers in a common procedure for its application, it serves to impress upon the public mind the fact, sometimes liable to be obscured, that Administration and Judiciary are both equally and alike functions of the same Government and inspired by a single purpose to maintain the 'King's Peace'. Such a utilitarian approach to the legal system was seen as natural by all ranks of the colonial administration. Commenting on the law, district commissioners and colonial office officials admitted that its restricting provisions were oppressive and illiberal. Yet, as Arthur Dawe, a senior official in London, stressed, such legislation might be reasonably applied in Cyprus, given that it had worked well in Palestine. He further stated:

[O]bjections to this type of legislation from the standpoint of British legal principles are obvious. But principles which will work here will not equally work in the special conditions of Cyprus [...]. [W] e must let the Governor have his way. He is evidently quite conscious of the unusual nature of the provisions [...]. But he is satisfied that no less drastic powers are necessary. As had been expected, the Prevention of Crime Law was welcomed not only by the village authorities, who had called for its introduction, but also by part of the rural population, which, in contrast to the townsfolk, suffered from petty crimes on a constant basis. "From the Shepherds' Licensing Law to the Goats (Amendment) Law, and from the Juvenile Offenders Law to the Prevention of Crime Law, the colonial authorities introduced a series of legislative initiatives in 1935 against rural crime. Along with the reorganization of the police and the intensification of patrols in the countryside, the number of minor offences in rural areas dropped during the first half of 1936. Mukhtars, azas and rural constables expressed their satisfaction with the deterrent effect of the law, as well as its ability to decrease the cases of animal-stealing, housebreaking and burglary. This led the Governor to note with satisfaction that the law was not perceived as arbitrary and extra-judicial by the rural population ${ }^{72}$.

In 1939, the trial of the Bishop Leontios would test the effectiveness of the law in handling political questions. Most importantly, the trial illustrated the

\footnotetext{
${ }^{71}$ In Ireland, the 1882 Prevention of Crime Act provided the Lord Lieutenant with the power to prohibit meetings and to order searches for documents. As the Chief Secretary for Ireland stated, commenting on the Law, its objective was to prevent political crimes and meetings as well as control subversive speakers and publications, even when an immediate breach of the peace was not expected. In the Channel Islands, the 1908 Prevention of Crimes Act provided that a dishonest or criminal life was admissible as evidence. Similar legislation was enacted in Kenya. Ibid.

${ }^{72}$ Ibid.
} 
significant role of the Church in Cypriot politics, with Leontios personifying the conflict against the colonial authorities.

His defence consisted of ten advocates from all across Cyprus, all of them important individuals within the Greek Cypriot community and prominent in the struggle against the colonial government. The team included Criton Tornaritis, Alekos Zenon, Lefkios Zenon and Pheidias Kyriakides from Limassol; Vias Markides from Nicosia; Christodoulos Galatopoulos and Sotiris Markides from Paphos; George Vassiliades from Larnaca; Andreas Gavrielides from Famagusta; and Savvas Christis from Kyrenia. In other words, the defence represented different generations and cut across political divisions within the Greek Cypriot community $^{73}$.

Some, like Gavrielides and Lefkios Zenon, both members of right-wing party EREK, were ardent nationalists. Alekos Zenon and Sotiris Markides had fought in the Balkan Wars as volunteers with the Greek army, while Kyriakides had been one of the leaders of the demonstration that attacked the government house in 1931. Others were affiliated to the Left, such as Kyriakides and Vassiliades, who would become founding members of left-wing party AKEL in April 1941, and Galatopoulos, who had been elected deputy at the legislative council with communist support and were later imprisoned for his role in the revolt. It is of particular interest that the defence team did not attempt to persuade the Court that the various speeches and sermons of the Locum Tenens - which constituted the main body of evidence offered by the prosecution - were innocuous and unthreatening. No attempt was made to reject the accusations, apart from that of promoting anti-British feelings. Throughout the cross-examination of the witnesses and in their addresses to the Court, the advocates focused on the historically Greek character of Cyprus and on Leontios' 'ethnarchic' (ethnic leading) role ${ }^{74}$.

According to the defence, these points made the actions and discourse of the Locum Tenens natural, if not imperative.

Even during cross-examination, the advocates attempted to highlight the links with Greek culture that the witnesses enjoyed. The defence argued that the dedication of Leontios to his ethnarchic duties, that is, the promotion of Greek culture and Orthodox faith, was not incompatible with loyalty to the British. It seems that the growing tensions in Europe and especially in the Eastern Mediterranean had caused concerns among Greek Cypriots that a potential departure of Britain from the island could only pave the way for the occupation of Cyprus from a different foreign power. In his own statement, the Locum Tenens defined himself as the 'Ethnarch' (Ethnic Leader) of the Greek Cypriot community, the defender of its holy and national traditions and the promoter of Greek education [' $\pi \alpha l \delta \varepsilon i \alpha$ '].138 Like his defence team, Leontios professed his loyalty to Great Britain, and, at the same time, his readiness to sacrifice himself for the sake of his congregation. At the same time, he invoked his spiritual role, refusing to take the oath and speak from the dock, while he employed a number of Biblical extracts in his address. His whole presentation seems to have been

\footnotetext{
${ }^{73}$ Kalantzopoulos (2015) at 86.

${ }^{74}$ Ibid.
} 
carefully prepared. When Leontios arrived at court on the first day of the trial, he was accompanied by 200 clerics and a clique of supporters ${ }^{75}$.

During the course of Leontios' address to the court, many in the audience and at least four of the advocates - were men, women and children gathered every day in the vicinity of the courthouse, and as the proceedings lengthened the crowds became larger. According to the report of the Deputy Commissioner of Police: On every appearance of the Bishop and his attendant priests in the streets long cheering and [...] clapping was heard [...].One school in the vicinity of the Bishopric [...] broke out of class and rushed on to the street to applaud the Bishop on his way to Court. The Bishop responded to the applause on all occasions by waving his hand and blessing the people [...].Occasionally cries of 'Zeto e Enosis' [Long Live Enosis] [...] were heard in the crowd. Large crowds gathered outside the Limassol Metropolis after the Bishop had returned there following the decision of the Court $[\ldots]$ and remained there until his departure at Paphos.

The trial had offered Leontios a great opportunity to restore the prestige of the Church, which had been greatly diminished by the archiepiscopal question and the issue of Church property. As such, the objective of the Locum Tenens and his defence team was not to secure acquittal, but to attach a political significance to the trial that would confirm the claim of the Church to Ethnarchic Leadership. Indeed, the trial highlighted the political unity of the Greek Cypriot community, under an emerging leader who could convincingly appear as the defender of its national interests. The Locum Tenens' persecution would, it was hoped, come to be inscribed as a symbolic sacrifice for the good of his congregation. In this sense, the trial developed into an absolute success for Leontios and a failure for the government. The British had only managed to restrict his physical movement within the municipal limits of Paphos, at the cost of enhancing his prestige. They would repeat the same mistake in 1956, with the exile of Archbishop Makarios III. Most importantly, all sides involved in the trial (the colonial authorities, the Church, the secular Greek Cypriot elite) regarded the process as a challenge to the political role of the Church. Because the accusations revolved around the political and secular, or ethnarchic, dimension of Leontios' activities, the British implicitly recognized the Church itself as a partially secular institution. The accusations, as well as the argumentation provided by the public prosecution and the Court, did not address the religious and spiritual authority of the accused. The British had seized an opportunity to further curtail the secular activity of the Church, after the successful measures against religious participation in the Greek Cypriot board of education and its local branches ${ }^{76}$.

The Court was mainly preoccupied with the content of Church discourse, not the presence of such activity - after all, the Muslim religious elite had also traditionally enjoyed a longstanding secular role, which the government sought to reinforce.

Conversely, the trial offered the Church an opportunity to secure its prominent political position on the island. The confrontation between the Church

${ }^{75}$ Ibid. 
and the government urged all Greek Cypriot political forces to support Bishop Leontios, creating a consensus among the previously competing factions.

That new understanding was made manifest in the composition of the defence team and the extensive coverage of the trial in most newspapers of the island, including those controlled by the secular elite and the left-wing Anexartitos (The Independent). In the following years, Leontios would successfully expand on his position as a prominent anti-government political figure and leader of the Greek Cypriot community ${ }^{77}$.

At the end of the hearings, the Court's President Wilkinson, issued a Court Order to mandatorily enforce the residence of Bishop Leontios within the municipal boundaries of the city of Paphos for a period of twelve months during which Bishop Leontios had to be under police surveillance.

After the Court Order was announced and Bishop Leontios' exited from the Court, many Greek Cypriots gathered around the Bishop and cheered for him. A strong police force intervened to dismantle the gathered people as illegal, because there had been a decision by the colonial authorities prohibiting any concentration within the municipal boundaries of Limassol. However, the crowds of hundreds of Greek Cypriots marched on the streets to Paphos, beyond the municipal boundaries, to salute Bishop Leontios who, in the meantime, after a brief rest in Metropolis, started travelling to Paphos. The Greek Cypriot residents of the suburbs of Kolosiou, Ypsonas, Erimi and Episkopi, went down to the main street to support him by handshakes and warm supportive words. Moreover, the Turkish Cypriot residents of the village Paramali shouted 'Yasasin' ('Long Live'). Near the village Ypsonas, students of the High School of Limassol and Nuns, offered to the Bishop Leontios flowers. And so, Leontios, having the support of both Greek Cypriots and Turkish Cypriots of village Paramali, headed again to Paphos, to mandatorily reside there for twelve months.

\section{Final Brief Remarks}

Bishop Leontios wanted and sought the Union of Cyprus with Greece. He fought for the Union, was tried three times and sentenced by the English courts mainly for his efforts to achieve the political union of Cyprus with Greece ('Enosis') and establish the Greek Orthodox religion in combination with the Greek education for Greek Cypriots. His efforts were continued by Archbishop Makarios III, and also by the members of the EOKA Struggle (1955-1959) ${ }^{78}$ to overthrow British rule from Cyprus until the establishment of the independent Republic of Cyprus in 1960.

'... From a psychological standpoint, the Englishman appeals to his material interests and his sense of law, but not to his heart or his imagination.

The Cypriot may respect the Englishman, but he cannot love him.

\footnotetext{
${ }^{77}$ Kalantzopoulos (2015) at 87.

${ }^{78}$ McDonough (2018).
} 
That is why he (the Cypriot) can never feel that he is a member of the British Commonwealth, while he feels he is a member of the Greek-speaking world.

London may be the commercial capital of Cypriots, but their intellectual, cultural and professional capital is Athens.

The Cypriots feel Greeks and therefore want to be Greeks.

This is the psychological foundation of the Unification' ${ }^{79}$

It is clear that the policy of the colonial Government abstained in the spirit of the fourteen Points of US President Woodrow Wilson as they were formulated in 1918, where there was a clear positive stance on self-determination and autonomy and the Protection of the rights of small countries. Two years after the last trial of Theodoros, in 1941, in the Atlantic Charter the President of the United States Fr. Roosevelt and British Prime Minister Winston Churchill will report on the right to self-determination of the people. What Leontios had been convicted of, two years later, would be proclaimed by the British Prime Minister as one of the basic principles governing the organisation of the international community after the end of World War II.

It should also be noted that six years later, on 26 June 1945, the UN Charter, which constitutes 'the ideological crystallization of the principles governing the post-war International society', was signed, where, in particular, article 1 (2) of the UN Charter has since been enshrined Principle of the self-determination of peoples.

\section{References}

Alecou, A. (2016). Communism and Nationalism in Post-war Cyprus, 1945-1955, Politics and Ideologies under British Rule. Palgrave, MacMillan

Antoniades, N.J. (2017). Ethnic Nationalism and Identity Formation in Cyprus, 1571 to 1974, Digital USD, MA in Leadership Studies Capstone Projects, 5-25. https://digi tal.sandiego.edu/cgi/viewcontent.cgi?article $=1004 \&$ context=solesmalscap

Georghallides, G.S. (1979). A Political and Administrative History of Cyprus, 1918-1926. with a Survey on the Foundations of British Rule. Nicosia: Cyprus Research Centre.

Georghallides, G. S. (1981-1982). 'Servitude Preferred' in Epeterida 11:275-334.

Georghallides, G.S. (1985). Cyprus and the governorship of Sir Ronald Storrs: the Causes of the 1931 Crisis. Nicosia: Cyprus Research Centre

Hadjichristodoulou, C. (2004). 'A Map of Cyprus in a Post-Byzantine Cypriot Icon, Institute for Neo-Hellenic Research' in Tetradia Ergasias 25-26, Eastern Mediterranean Cartographies 337-346. http://www.ine-notebooks.org/index.php/te/article/ viewFile/120/176

Heraclidou, A. (2017). Imperial Control in Cyprus, Education and Political Manipulation in the British Empire. London - New York: I. B. Tauris \& Co. Ltd.

Ioannides, C.P. (2019). Cyprus under British Colonial Rule, Culture, Politics, and the Movement toward Union with Greece, 1878-1954. New York - London: Lexington Books, Lanham, Boulder

Kalantzopoulos, D. (2015). 'Competing Political Spaces in Cyprus, 1931-1950'. PhD Thesis, King's College London. https://core.ac.uk/download/pdf/83947709.pdf

\footnotetext{
${ }^{79}$ Kinross (1951) at 111.
} 
Kinross, P.B. (1951). The orphaned realm; Journeys in Cyprus. London: P. Marshall.

Louth, A. (2012). Leontios of Neapolis. https://doi.org/10.1002/9781444338386.wbeah03 145

McDonough, R. (2018). 'What caused the division of the Island of Cyprus?' https://www. iwm.org.uk/history/what-caused-the-division-of-the-island-of-cyprus

Pafitou, N. (2010). Bank of Cyprus Chronicle 1899-2009, Historical Archives of the Bank of Cyprus. https://www.bankofcyprus.com.cy/globalassets/cyprus/istoriko-arhio/his tory/boc-chronicle_english-allagi.pdf

Papageorgiou, T. (2008). The Legal Prosecutions against Bishop of Paphos Leontios during the Palmerocracy (in Greek), Epeterida Kentrou Meleton Ieras Monis Kykkou, 471-480

Rappas, A. (2008). 'The Elusive Polity: Imagining and Contesting Colonial Authority in Cyprus during the 1930s' in Journal of Modern Greek Studies, 26(2):363-397. https://www.academia.edu/1081657/The_Elusive_Polity_Imagining_and_Contesting _Colonial_Authority_in_Cyprus_during_the_1930s

Rappas, A. (2014). Cyprus in the 1930s - British Colonial Rule and the roots of the British Colonial Conflicts. London - New York: I.B. Tauris \& Co. Ltd.

Sir Oakden, R. (1935). Report on the Finances and Economic Resources of Cyprus. London: Crown Agents for the Colonies

Stamelos, H. (2018). History of Law of Greece and Cyprus (in Greek), Athens: Nomiki Bibliothiki.

Stamelos, C. (H.). (2019). 'Ancient Cypriot Kingdoms: Political and Legal Aspects of Their Regimes (1200 BC to 30 BC)' in D.A. Frenkel \& N. Varga (eds.) New Studies in History and Law, Athens Institute for Education and Research, 121-132.

Surridge, B.J. (1930). The Survey of Rural Life in Cyprus. Government Printing Office: Nikosia

Tsimaras, K. \& H. Stamelos (2019). The Three Historic Criminal Trials of Bishop of Paphos Leontios During the British Rule in Cyprus $(1932,1938,1939)$ (in Greek), forthcoming.

University of Central Arkansas, 30. British Cyprus (1914-1960). https://uca.edu/politicals cience/dadm-project/europerussiacentral-asia-region/british-cyprus-1914-1960, 2004

Voudouris, A. (2015). 'The Ecclesiastical Problem of Cyprus during the Period 19331947' (in Greek). PhD Thesis, University of Thessaloniki. at https://ikee.lib.auth.gr/ record/286215/files/voudouris\%20athanasios.pdf

\section{Other Sources}

Stamelos, H. et al. 2018. Moot court, the three criminal trials of Bishop of Paphos Leontios, European University Cyprus Law School, Nicosia

Storrs, R. (1937). Orientations. London: Ivor Nicholson and Watson.

Storrs, R. \& B.J. O'Brien (eds.) 1930. The Handbook of Cyprus. London: Christopher's.

Stubbs, S.R.E. (1933). Memorandum. London: Ivor Nicholson and Watson.

\section{Cases}

Cox v. Louisiana, 379 US 536 (1965)

$R v$ Howell (1982) QB 416 



\title{
A Right of Access to Medical Records: The Contemporary Case Law of the European Court of Human Rights and the Jurisprudence of Germany
}

\author{
By Anatoliy A. Lytvynenko*
}

The right of access to medical records is a secondary contractual right originating from the patient's right to self-determination, and is exercised prior to commencing a malpractice action, or, in less commonly, for private discovery. This right is countered by the physician's obligation to medical secrecy as well as therapeutic concerns, mainly in order not to harm the patient's physical and mental condition, a qualification which is frequently applied in psychiatric cases. The jurisprudence of the Commonwealth countries and Continental Europe is quite versatile and controversial. The subject has also launched several actions adjudicated by the European Court of Human Rights. The latter court, however, still lacks a thorough and comprehensive jurisprudence on the right of access to medical records, though it is quite clear that such actions will have to be addressed more frequently by the ECHR in the near future. For these reasons, the European Court of Human Rights urgently requires a number of general rules upon which these lawsuits may be decided. Therefore, the author of the paper intends to analyse the jurisprudence of the Republic of Germany in order to align and specify general rules concerning access to medical records and the restrictions of exercising this right. The choice of German jurisprudence is dictated by the fact that German courts have developed a firm body of case law regarding access to medical records, encompassing diverse judgments with complicated and outstanding circumstances, which may be useful for the courts in Continental Europe as well as the European Court of Human Rights.

Keywords: data privacy; right to self-determination; medical confidentiality; medical malpractice; European Court of Human Rights; German medical law.

\section{Introduction}

In German jurisprudence, the patient's right to access their medical records derives from the patient's right to self-determination and dignity, which presupposes that a patient may not be regarded as a mere object of treatment with no actual rights. ${ }^{1}$ This right includes access to diverse types of medical records,

\footnotetext{
* PhD (Law) Student, Ivan Franko National University of Lviv, Ukraine; PhD (Law) Student, Robert Gordon University of Aberdeen, Scotland, UK. E-mail: anat.lytvynenko@gmail.com.

${ }^{1}$ See $B G H, 23.11 .1982$; VI ZR 222/79, para. 16.
} 
such as those describing their current state of health and prognosis for the future. ${ }^{2}$ There are many types of medical records; ${ }^{3}$ minor medical records may be very accessible, ${ }^{4}$ while others, such as psychiatric records, may have limited accessibility. ${ }^{5}$ Most often, the medical records are accessed prior to the commencement of a malpractice action against a hospital or a physician(s), which is frequent for common law jurisdictions, such as England ${ }^{6}$ or the United States. ${ }^{7}$ In Germany, the patient has no actual obligation to demonstrate a legal interest in obtaining health records in conventional cases ${ }^{8}$ (though in some earlier cases they were requested as proof). ${ }^{9}$ The German case law repeatedly affirmed that a patient's right to access his medical records is a "case law-bred" right deriving from the contract of treatment between patient and physician or hospital, ${ }^{10}$ whereas in some civil law jurisdictions, such as France, patients have a statutory right to access their medical records based upon Civil Code provisions. ${ }^{11}$ In the early stages of the jurisprudence on the subject, both $\mathrm{US}^{12}$ and German ${ }^{13}$ commentators concluded there must be a common law-originating right to access to medical records. The further development of patient's rights with respect to privacy was also reflected in the international human rights courts.

The timeline of the subject depends on jurisprudence both in "common law" and "civil law". For instance, the right to access medical records in England resulted from a 1970 act, which allowed records to be produced as documentary evidence for trial. Prior to this, according to the English courts, medical records were produced only upon a subpoena. ${ }^{14}$ The 1970 s jurisprudence of England allowed very restricted access to records and did not grant it to the plaintiff himself, limiting it only to legal and medical advisors: ${ }^{15}$ in the 1970 s, the courts followed the hospital record-keeping practices which held that patients should not be allowed to examine their medical data, as it may be detrimental for them, the prognosis may be depressing, they may be unable to comprehend the information properly and, finally, that physicians might avoid putting important information in

${ }^{2}$ OLG Bremen, 31.07.1979 - 1 U 47/79, para. 15 In Re D (Infants), [1970] 1 W.L.R. 599, 600-603.; $D$ v. NSPCC, [1978] A.C. 171 at. $242-246$.

${ }^{3}$ Wischmach (1998) at 241-242.

${ }^{4}$ See e.g. $B G H, 23.11 .1982$ - VI ZR 222/79, para. 17-30.

${ }^{5}$ See e.g. $B G H, 06.12 .1988$ - VI ZR 76/88, para. 7, 9.

${ }^{6}$ See Dunning v United Liverpool Hospitals' Board of Governors, [1973] 1 W.L.R. 586; Deistung v South West Metropolitan Regional Hospital Board, [1974] 1 W.L.R. 213; Davidson v Lloyd Aircraft Services Ltd., [1974] 1 W.L.R. 1042; McIvor v Southern Health \& Social Service Board, [1978] 1 W.L.R. 757; Gaskin v. United Kindgom (1989) 12 EHRR 36, and Church of Scientology v DHSS, [1979] 1 W.L.R. 723.

${ }^{7}$ Cannell. Medical and Surgical Clinic, 315 N.E.2d 278, 280 (1974).

${ }^{8} B G H, 31.05 .1983$ - VI ZR 259/81, para. 7-8; BGH, 02.10.1984 - VI ZR 311/82, p. 5.

${ }^{9}$ OLG Koln, 12.11.1981, 7U 96/81, para. 18.

${ }^{10}$ See $B G H, 23.11 .1982$; VI ZR 222/79, para. 15 .

${ }^{11}$ See Demont (2000) at 76-79.

${ }^{12}$ See Harpst (1962) at 273-275; Dworkin (1979) at 90-91; Feenan (1996) at 101-102, 105-106.

${ }^{13}$ See Deutsch (1992) at 179-171.

${ }^{14}$ Davidson v Lloyd Aircraft Services Ltd., [1974] 1 W.L.R. 1042, 1045.

${ }^{15}$ See e.g. Dunning v United Liverpool Hospitals' Board of Governors, [1973] 1 W.L.R. 586, 590; Deistung v South West Metropolitan Regional Hospital Board, [1974] 1 W.L.R. 213, 216-217. 
writing for fear that the patient might gain access to the records. ${ }^{16}$ Though the McIvor judgment rejected most of these restrictions, especially that which allowed withholding the records from the plaintiffs themselves, ${ }^{17}$ English courts allowed hospitals to use their discretion while deciding whether there is public interest in withholding the records, and the restrictions concerning "deplorability" remained (thus provoking the Gaskin trial at the European Court of Human Rights) ${ }^{18}$ as well as denying access to avoid abuse of process. ${ }^{19}$

The English courts also held that childcare reports involving medical records are strictly confidential and "public interest" makes their disclosure impermissible. ${ }^{20}$ The Scottish case law is a bit younger than its English counterpart and strictly adheres to considerations of the applicant's legal interests. ${ }^{21}$ The US jurisprudence dates back to the forties and the earlier cases were entirely connected to malpractice suits. ${ }^{22}$ Some American courts recognised furnishing medical records as a common law duty of the physician or hospital, ${ }^{23}$ or a statutory one. ${ }^{24}$ In fact, the German courts also upheld the notion that access to records is a case laworiginating right. ${ }^{25}$ In spite of the fact that German courts faced suits regarding granting access to medical records in the 1970s, the right to inspect the records, as an expansion of the right to autonomy or self-determination, was recognised by the German Federal Constitutional Court only in $1998 .{ }^{26}$ In Austria, the right to access medical records was recognised by the Supreme Court in $1984 .^{27}$ Some common law jurisdictions hadn't been required to address similar suits prior to the last few decades; for instance, the Australian High Court found there was no common law right granting access to one's health records. ${ }^{28}$

\section{The Existing Jurisprudence of the European Court of Human Rights}

In the last three decades, the European Court of Human Rights has repeatedly faced suits involving data privacy, as well as a number of actions involving the right to self-determination. All of the given lawsuits were cognizant under Art. 8 of the ECHR, though data privacy is only one of the constituents that form the body of jurisprudence settled upon in the aforementioned provision. In some

\footnotetext{
${ }^{16}$ Davidson v Lloyd Aircraft Services Ltd., [1974] 1 W.L.R. 1042, 1045-1046.

${ }^{17}$ McIvor v Southern Health \& Social Service Board, [1978] 1 W.L.R. 757, 760-761.

${ }^{18}$ Gaskin v United Kindgom (1989) 12 EHRR 36.

${ }^{19}$ Church of Scientology v DHSS, [1979] 1 W.L.R. 723, 728 and seq.

${ }^{20}$ See e.g. In Re D (Infants) [1970] 1 W.L.R. 599, 600-603.; D v NSPCC, [1978] A.C. 171, 242-246.

${ }^{21}$ Boyle v Glasgow Royal Infirmary and Associated Hospitals, 1969 SC 72; 1969 S.L.T. 137.

${ }^{22}$ Hoyt v. Cornwall Hospital, 169 Misc. 361, 363 (N.Y. 1940); In re Weiss, 147 N.Y.S 2d. 455, 456 (1955).

${ }^{23}$ See Cannell v. Medical \& Surgical Clinic S.C., 315 N.E.2d 278, 280 (1974); Rabens v. Jackson Park Hospital Foundation, 40 Ill.App.3d 113, 116; 351 N.E.2d 276, 279 (1976).

${ }^{24}$ Clay v. Little Co. of Mary Hospital, 277 Ill.App.3d 175, 178-180; 213 Ill.Dec. 866, 868-869; 660 N.E.2d 123, 125-126 (1995).

${ }^{25} B G H, 31.05 .1983$ - VI ZR 259/81, para. 12.

${ }^{26}$ BVerfG, 16.09.1998 - 1 BvR 1130/98, para. 9-11.

${ }^{27}$ See $O G H 23.5 .1984,1$ Ob 550/84

${ }^{28}$ Breen v Williams, [1996] H.C. 78,
} 
recent cases, a breach of Art. 10 of the ECHR (in the sense of "receiving" information) was also alleged in conjunction with a refusal to release governmental records (though not strictly hospital records, as in the European Court's trials or German cases which will be discussed in the next sections). ${ }^{29}$ Some other trials have involved the retention of records concerning employment, military service, political party membership and trade union involvement; ${ }^{30}$ an attempt to receive an order to disclose one's data from intelligence service archives, ${ }^{31}$ a number of trials concerning health records (which we will briefly discuss in the following chapter), ${ }^{32}$ the retention of personal data in intelligence service archives ${ }^{33}$ or police archives, ${ }^{34}$ as well as banking confidentiality ${ }^{35}$ and the retention of medical records. ${ }^{36}$

The leading case on this subject is the Gaskin trial. The initial suit was brought in 1980, when the plaintiff, a young man possessing a "bad record", was unable to find himself an appropriate job. For years, the plaintiff had grown up in several foster homes, orphanages and infirmaries, until he came of age. Now, he blamed the defendant (the Liverpool City Council) for negligent care, as throughout the years he had suffered from various health problems, including psychiatric issues. In order to substantiate his case, he applied to the city council to gain access to his old medical records, which he intended to share with his advisors. However, the English court concluded that childcare reports may not be revealed, as there is substantial public interest in preserving them in full confidentiality, ${ }^{37}$ and cited in its decision a number of older lawsuits involving access to childcare reports. ${ }^{38}$ The European Court, after having assessed the key facts of the case, affirmed cognizance of the action under Art. 8 of the Convention, finding that the right of access to health records falls within the scope of the aforesaid provision. The European Court decided for the plaintiff, finding that he had a well-established legal interest in his health records, as this issue apparently belonged to "the right to private and family life." In addition, he didn't have an independent judicial body to appeal to. ${ }^{39}$ A similar suit appeared before the court

\footnotetext{
${ }^{29}$ Roche v United Kingdom [2005] ECHR 956, para. 170-172. In this case, the plaintiff desired to obtain records confirming he had been injured while being on military service in the 1950s, in order to enable him to receive a "service" pension. These were no hospital records, as I mentioned before, but only governmental records, though medical-related. Though the plaintiff didn't prevail in action upon Art. 10, he managed to recover on the basis of a violation of his right to privacy. It should be also noted that multi-claim lawsuits are quite frequent in the European Court. For instance, in Leander, the plaintiff invoked not only an Art. 8 and 10 breach, but Art. 14 (a right to an effective domestic remedy) as well. However, he didn't prevail on any of the counts.

${ }^{30}$ Leander $v$ Sweden [1987] 9 EHRR 433.

${ }^{31}$ Szulc v Poland, [2013] 57 EHRR 5, 163-167 (the trial facts are stated on the pages cited herein).

${ }^{32}$ See e.g., Odievre v France, [2003] F.C.R. 621.

${ }^{33}$ See Rotaru v Romania, [2000] ECHR 92, para. 43

${ }^{34}$ See Khehili v Switzerland, [2011] ECHR 195, para. 15 etc. (reported under the name Affaire Khelili c Suisse in French).

${ }^{35}$ B.F.B. Villa-Nova v Portugal, [2015] ECHR 1049; GSB v Switzerland, [2015] ECHR 1122, para. 75-98.

${ }^{36} S$ \& Marper v United Kindgom, [2008] ECHR 1581.

${ }^{37}$ Gaskin v Liverpool City Council, [1980] 1 W.L.R. 1549, 1552-1553 [per Denning, L.J]

${ }^{38}$ See In Re D (Infants), [1970] 1 W.L.R. 599, 600-602 etc.; D v NSPCC, [1978] A.C. 171, 242-246.

${ }^{39}$ Gaskin v United Kindgom (1989) 12 EHRR 36.
} 
in the mid-1990s, $M G v$. United Kingdom. The facts were basically similar to the Gaskin trial: the plaintiff had grown up in a number of orphanages. As an adult, he attempted to obtain access to his childcare reports, in order to reconstruct his memories concerning his early years (mid-1960s to early 1970s), and especially facts regarding violent abuse by his (now deceased) father. He also planned to sue the municipal authorities in case the medical records displayed any malpractice by the municipal bodies regarding his custody. Though upon his earlier requests he managed to obtain insight to a number of documents, those did not relate to most of his adolescent years, which were seemingly concealed and not entrusted to him. The verdict was the same: the European Court found that plaintiff had a vital interest in his medical records, and again, no independent judicial body to appeal to, stating that he prevailed in action under Art. 8 of the Convention. ${ }^{40}$

Another interesting lawsuit was Odievre v. France, an example of a sophisticated action concerning the wish to gain access to adoption records in order to reveal the identity of the biological parent. These trials are quite complex, as adoption records possess a high degree of confidentiality, meaning the plaintiff has little chance to prevail in court. For instance, American scholars in the 1970s were confident that it was the United States' state policy to keep such records sealed $^{41}$ (and thus referred to as "sealed records"). This policy was rarely overturned, and only on occasions when the plaintiff proved that the revelation was necessary for property inheritance, ${ }^{42}$ or implied some medical reasons to access the sealed records. ${ }^{43}$ The US jurisprudence also faced tort actions for the wrongful disclosure of adoption records concerning a biological mother. ${ }^{44}$ The German legislature asserted a prohibition on revealing adoption files, though not unqualified: these records may be disclosed if a strong justifiable interest is shown, and if all parties (e.g. biological sisters, brothers etc.) gave consent to the disclosure. ${ }^{45}$ This approach arose from a French civil law concept of the "l'accouchement secret", or "Accouchement sous X", upon which the records of biological parents are supposed to be eternally confidential. The legal framework of the concept is mostly based upon a 1904 law. ${ }^{46}$ The French jurisprudence of the $19^{\text {th }}$ century recognised birth records to be highly confidential and even physicians found reporting personal data outside the scope of civil code demands to be a breach of confidence (even in cases reported to public bodies, but not to any third parties). ${ }^{47}$

\footnotetext{
${ }^{40}$ MG v United Kindgom, App. 39393/98, judgment of 29 Sept. 2002,

${ }^{41}$ Crane (1986) at 647.

${ }^{42}$ Massey v. Parker, 369 So. 2d 1310, 1313-1315 (La. 1979).

${ }^{43}$ Kirsch v. Parker, 383 So. 2d 384, 387-388 (La. 1980).

${ }^{44}$ See Humphers v. First Intestate Bank, 298 Or. 706; 696 P. 527, 533-536 (Or. 1985).

${ }^{45}$ OLG Bayern, 07.02.1996 - 1 Z BR 72/95, para. 9-11.

${ }^{46}$ Bulletin officiel du Ministère de l'intérieur (1904) at 282-283. Concerning the French legislature's initiatives on "l'accouchement secret" and their application, see Passion (1983) at 478 et seq.

${ }^{47}$ See e.g. Mallet, 16 Sept. 1843, Cour de cass.; Ch. Crim., Sirey 1843 I 915, at p. 916; 918-919. In this trial, a physician from La Rochelle reported the birth records of a newly-born child to a town's registrar. As he was at the confinement, he was obliged to report it under the law within 3 days (Art. 56 Cod. Civ.; Sirey 1844 I 669, 671-672). He refused to reveal the mother's name for unspecified reasons, with a reference to medical secrecy. He was prosecuted, but won the appeal. The court of cassation affirmed the lower court's judgment, stating he was not obliged to report more than the
} 
As the legal concept progressed, being codified in the Civil Code, it received a more elaborate legal regulation. The Odievre trial resulted from this concept. The plaintiff, a French national born in 1965, was abandoned by her parents at birth. In the late 1960s, she was adopted and carried another surname (under which she sued) thereafter. While in her $30 \mathrm{~s}$, the plaintiff applied to a local child welfare service located in Seine to obtain the information concerning her biological parents. The plaintiff also believed she had siblings. But the only document she managed to receive were anonymised records, which were apparently valueless to her. As the appeals were unsuccessful, she lodged a suit to the European Court of Human Rights. The court, having recognised cognizance over the case, held that though it was not very typical to have legislation and case law allowing anonymous childbirth in much of Europe, ${ }^{48}$ this was not true for France, which had a long legal tradition of recognizing anonymous births. Furthermore, existing French legislation and jurisprudence allowed access to depersonalizsed records, meaning the plaintiff was not (in the stringent sense of the word) deprived of her informational rights. Thus, the court affirmed the French ruling. ${ }^{49}$ The ruling of Godelli v. Italy, with nearly identical facts, was somewhat reversed. The plaintiff, an elderly woman, decided to discover her origins. She was born in 1943 and adopted at the age of 6 . In her youth, she discovered that a girl from her village was also adopted, but the adoptive parents of both repeatedly suppressed any contacts between them and never disclosed the true identity of her parents. At age 63 (in 2006), the plaintiff applied to the town register to receive her birth records, but her request was denied. Her lawsuits at the trial and appellate courts were unsuccessful. ${ }^{50}$ The court found that the Italian civil law provisions on the subject granted access only in two cases: 1) a qualified one - to the physician; 2) upon a court order, if the plaintiff is over 25 , and there are medical reasons for the disclosure. The court found that though anonymised childbirth is quite rare in Continental law jurisdictions, it is not as rare as would be expected. ${ }^{51}$ At trial before the European Court, the woman claimed that she had been unable to receive non-identifying data, putting the count upon Art. 8.1 of the Convention. The court, assessing the balance, stated that privacy rights are expected to be balanced between two competing private interests - those of the person given up for adoption, and those of the birth parents. In Odievre v. France, the plaintiff easily received depersonalised birth records, of which she had been deprived in the instant case. ${ }^{52}$ The court, attempting to be as fair as possible, stated that the plaintiff, being nearly 70 years of age (at the time of the trial) had attempted to trace her origins, a desire that doesn't vanish with age. Italian law, unlike its French counterpart, did not provide an adequate balance by lodging a possibility to

infant's personal data. Despite the fact that in earlier times lower French courts interpreted it differently, this approach was accepted and applied in succeeding trials with identical circumstances, Romieux c. Min. Publ, 1 Juin 1844, Cour de cass; Ch. Crim., Sirey 1844 I 669, 672.

${ }^{48}$ See also Godelli v Italy, [2012] ECHR 347, para. 28-31.

${ }^{49}$ Odievre . France, [2003] F.C.R. 621, para. 15-onw.

${ }^{50}$ Godelli v Italy, [2012] EC.HR 347, para. 7-15 (statement of facts).

${ }^{51}$ Godelli v Italy, [2012] ECHR 374, para. 18-23; 28-31 (concerning the analysis of Italian civil law and jurisprudence).

${ }^{52}$ Odievre v France, [2003] F.C.R. 621, para. 12. 
inspect anonymised childbirth records. Therefore, the court found in favour of the plaintiff, stating that her right to privacy had been violated. ${ }^{53}$

Although the European Court of Human Rights possesses some jurisprudence on the subject of access to medical records, the existing case law is far from enough to be able to elaborate general rules on the right to access and its exemptions. By means of analysing various Commonwealth and Continental Europe jurisprudence, this may be substantially enhanced. In one of my recent papers, ${ }^{54}$ I demonstrated the trends in the United Kingdom and American jurisprudence on the subject from the perspective of the Anglo-American law.

\section{General Assumptions Regarding Access to Health Records in German Jurisprudence}

The right of access to medical records is a contractual right and subsequently derives from the contract between the patient and physician. ${ }^{55}$ This is also the position of the Austrian courts. ${ }^{56}$ According to some courts, the right of access to medical records derives from the patient's right not only to a diagnosis and therapy, but to information concerning their medical records, which may be related to their current state of health and future prognosis. ${ }^{57}$ This is in addition to the right to autonomy, or self-determination, which, apart from informed consent ${ }^{58}$ (including, in more recent jurisprudence, a consent to transferring medical data from one medical institution to another), ${ }^{59}$ involves an informational right of access to medical records. ${ }^{60}$ According to applicable German case law, special provisions concerning the patient's right to access are not required, making it practically a "common-law" right. ${ }^{61}$ In fact, in the late 1970s, a Limburg regional court expressed a dictum upon which there may be a contractual provision restricting access to medical records in some "exceptional" circumstances (though

\footnotetext{
${ }^{53}$ Godelli v Italy, [2012] EC.HR 374, para. 50; 54-56; 57-59.

${ }^{54}$ See Lytvynenko (2019a).

${ }^{55}$ See the following decisions: $A G$ Weltzar, 15.08 .1978 - 3C 707/78, para. 8-9 and 15; LG Gottingen, 16.11.1978 - 2 O 152/78, para. 9-10; 16; BGH, 23.11.1982; VI ZR 222/79, para. 15; BGH, 31.05.1983 - VI ZR 259/81, para. 9; OLG Munchen, 19.04.2001 - 1 U 6107/00, para. 21.

${ }^{56}$ OGH 23.05.1984, 1 Ob. 550/84.

${ }^{57}$ OLG Bremen, 31.07.1979 - $1 \mathrm{U} 47 / 49$, para. 15.

${ }^{58}$ See, for instance, $B G H, 16.01 .1959$, VI ZR $179 / 57$, para. $14-16$, etc. There, the plaintiff was not informed of the potential hazards of radiotherapy treatment. The case was won on the basis of breach of contract/breach of duty to inform. This leading case raised the concept of "selfdetermination" ("Recht der Selbstbestimmung") in German jurisprudence (see para. 15 of the judgment in particular). The 1950s (or earlier) case law acknowledged a duty to inform the patient only of frequent side effects, see $B G H, 11.04 .1956$ - VI ZR 20/55, para. 10-12. However, in cases where negligence was proved, the plaintiff was able to win a malpractice suit on this basis.

${ }^{59}$ See AG Neunkirchen, 28.10.1991, 5 C 648/91, para. 12-onw. Concerning the right to autonomy see para. 16. There the court held that the transfer of an elderly patient's medical data from a hospital to a clearinghouse without written consent is void.

${ }^{60}$ OLG Bremen, 31.07.1979 - 1 U 47/79, para. 15.

${ }^{61} B G H, 31.05 .1983$ - VI ZR 259/81, para. 12.
} 
not specified in the judgment) or there may be a special contract between the patient and physician or hospital concerning such restrictions. ${ }^{62}$

In comparison to commonwealth states, such as Scotland, ${ }^{63}$ the patient conventionally does not need to display any legal interest in obtaining access to medical records. ${ }^{64}$ In certain civil actions involving confidential medical records, such as psychiatric data, or rights of heirs to access the deceased person's health data, ${ }^{65}$ the court may request that the plaintiff justify their request to access the medical records. ${ }^{66}$ In some earlier judgments, the German courts held that a plaintiff was allowed access to medical records in cases in which they had a substantial legal interest, most often when preparing a medical malpractice suit. ${ }^{67}$ In the early 1980s, the Supreme Court announced a variety of cases in which access to medical records may be limited, ${ }^{68}$ or restrictions imposed upon very sensitive personal information. ${ }^{69}$ Similarly, the court ruled that, as in England ${ }^{70}$, the USA ${ }^{71}$ and Canada, ${ }^{72}$ the physician or a hospital is the owner of their patients' medical records, but their property rights are limited and qualified to the patient's right to access them; ${ }^{73}$ The property rights may not serve as an excuse not to produce medical records upon request. In a 2001 OLG Munich decision, for instance, after having suffered a brain injury and being unsuccessfully treated, the plaintiff applied to the hospital to obtain photocopies of their MRI, computerised tomography and other records, promising to return them in 6 months. The defendant refused, inter alia, claiming that the production of these documents may adversely affect the hospital's property rights, and offered photocopies of the material instead. The court determined that this solution did not comply with the defendant's contractual obligation to supply the records, and held they such records are quite frequently disposed at trial and damage to them is rare. In this

\footnotetext{
${ }^{62}$ LG Limburg, 17.01.1979 - 3 S 244/78, para. 13.

${ }^{63}$ See generally, Boyle v Glasgow Royal Infirmary and Associated Hospitals, 1969 S.C. 72; 1969 S.L.T. 137.

${ }^{64} B G H, 31.05 .1983$ - VI ZR 259/81, para. 8; BGH, 02.10.1984 - VI ZR 311/82; at p. 5.

${ }^{65} B G H, 31.05 .1983$ - VI ZR 259/81, para. 19-20.

${ }^{66}$ See e.g. LG Saarbrucken, 20.09.1995 - 16 S 1/93, para. 7.

${ }^{67}$ OLG Köln, 12.11.1981: 7 U 96/81, para. 18.

${ }^{68} B G H, 23.11 .1982$; VI ZR 222/79, para. 17-et seq.

${ }^{69} \mathrm{BGH}, 06.12 .1988$ - VI ZR 76/88, para. 7.

${ }^{70}$ R. v Mid Glamorgan Family Health Services Authority \& Another/Ex Parte Martin, [1995] 1 W.L.R. 110, 116; 119-120.

${ }^{71}$ In Re June 1979 Allegheny County Grand Jury Investigation, 415 A.2d 73, 76-77 (1979).

${ }^{72}$ This issue in Canada is quite complicated. The leading opinion of McInerney v Macdonald, [1992] 2 S.C.R. 138, where a patient merely requested to examine an entire medical file and was refused, didn't display a firm application of property rights, as the Supreme Court based its decision upon the fiduciary duty of a physician (see p. 150-152). At the same time, there are some decisions of lower Canadian courts where the hospitals or doctor's property rights in medical records were firmly recognised, see Lamothe v. Mokleby \& Erle Holdings Co., 106 D.L.R. (3d) 233 (1979), para. 8-9; Re Mitchel \& St. Michael's Hospital, 112 D.L.R. (3d) 360 (1980), para. 10-11. The former case, however, dealt with the proprietary status of medical records in terms of their purchasing alongside with other property.

${ }^{73} B G H, 23.11 .1982$; VI ZR 222/79, para. 16.
} 
matter, the property status of the records was not actually addressed, and the plaintiff's counsel guaranteed their safety, thus the appeal was dismissed. ${ }^{74}$

It is possible that the denial of access to medical records by the physician or hospital may be justified and substantial opposing interest may be displayed at trial. $^{75}$ Even in cases where the patient requests highly-confidential medical records (most often those relating to psychiatric treatment), ${ }^{76}$ a decision to allow only limited access, deemed by the court under the label of "therapeutic reasons", ${ }^{77}$ must be justified by defendant hospitals by precise facts (e.g. worsening of a patient's condition in the last few years, which may become further aggravated if the records are not concealed and handed over to plaintiff). ${ }^{78}$ The limited access may be justified based on an evaluation of their potential influence on the plaintiff's disease and their current health condition. ${ }^{79}$ People who are detained in psychiatric facilities cannot be deprived of their right to inspect medical records, and in psychiatric cases, an exact and sufficient risk of an illness reoccurring may justify the restriction. ${ }^{80}$ More recent case law grants a right of access to medical records not only to people who are detained in psychiatric facilities, but to prisoners serving their sentence as well; however, there may be additional procedures to implementing this right, taking into account the fact these people are in isolated institutions, as a mental facility, a reformatory or a prison. ${ }^{81}$ In some psychiatric cases, the records may be disclosed to the plaintiff in the presence of his medical advisor or a consulting physician, especially if there are grounds to believe that the information contained in the records may adversely affect the plaintiff's mental condition $^{82}$.

The patient being treated at the hospital where all their records are maintained, has a qualified property right to them Upon their death, this right might be transferred to their heirs unless the deceased clearly stated their objection to this before their demise. ${ }^{83}$ The right of access to medical records is frequently contradicted by the physician's obligation to maintain medical secrecy. In German jurisprudence, the term "breach of medical confidentiality" may refer to: a) an exemption of a physician, ${ }^{84}$ a nurse ${ }^{85}$ or other hospital staff to testify at trial

\footnotetext{
${ }^{74}$ OLG Munchen, 19.04.2001 - 1 U 6107/00, para 2-13 (facts); para. 25-26 (concerning damage to records).

${ }^{75}$ See e.g. OLG Köln, 12.11.1981: 7 U 96/81, para. 20-21; OLG Karlsruhe, 36.03.2007 - 2Ws $322 / 06$, para. 3 .

${ }^{76}$ See also comment, BVerfG, 16.09.1998 - 1 BvR 1130/98, para. 4.

${ }^{77} B G H, 06.12 .1988$ - VI ZR 76/88, para. 9.

${ }^{78} B G H, 06.12 .1988$ - VI ZR 76/88, para. 7-10.

${ }^{79} B G H, 02.10 .1984-$ VI ZR $311 / 82$ at p. 5.

${ }^{80}$ OLG Karlsruhe, 36.03.2007 - 2Ws 322/06, para. 3, 4-5.

${ }^{81}$ OLG Hamm, 23.02.2012 - 1 Vollz (Ws), 653/11, para. 13-21 and see other German court decisions cited.

${ }^{82} B G H, 06.12 .1988$ - VI ZR 76/88, para. 9-10.

${ }^{83} B G H, 31.05 .1983$ - VI ZR 259/81, para. 17-18; 20.

${ }^{84}$ See e.g. BVerWG, 25.09.1958 - BVerWG WDB 9/58 (A physician refused to testify in a suicide trial and was fined, appeal dismissed).

${ }^{85} B G H, 20.02 .1985$ - 2 StR $561 / 84$, para $7-11 ; 13-14$. (A nurse refused to testify concerning two burglars, one of whom was shot during an unsuccessful robbery of an electric shop. However, she was not allowed to conceal the facts beyond the treatment of the patient).
} 
concerning one's state of health, treatment and similar facts in both civil and criminal actions, which is quite far from being absolute, especially in the latter case; b) a breach of privacy by disclosing a patient's health data to third parties this may be any disclosure, from divulging the contents of a patients' list, ${ }^{86}$ to sharing one's medical records with non-medical hospital staff. ${ }^{87}$ Undoubtedly, disclosure of medical records may cause harm to the plaintiff, e.g. obtaining or extending a driving license, but it may pursue a legitimate aim. ${ }^{88}$ The demise of the individual, who is the subject of the requested medical records, does not waive the confidentiality of the records, but it may be overridden by a substantial legal interest, e.g. to define the cause of death and, if negligence is proved, to sue for damages. ${ }^{89}$ In fact, in some Continental Europe countries, such as France ${ }^{90}$ and Belgium $^{91}$, the disclosure of one's health data had been criminalised by penal code provisions from quite an early date. Medical secrecy was also touched upon by the European Court of Human Rights in the trial of $Z$ against Finland. ${ }^{92}$

\section{The Development of German Jurisprudence Regarding Access to Medical Records, its Boundaries and Limitations}

The right of access to medical records, being performed either for bringing a malpractice, personal injury or wrongful death suit against a physician or a hospital, or for private discovery, was introduced into German case law in the late 1970s, not much later than in England. Several decisions, where courts ruled that there must be a nearly unlimited exercise of the right of access to medical records, occurred in 1978-79. In the 1978 decision of a regional court in Weltzar, the facts were simple. The plaintiff and his spouse requested a hospital to provide health

\footnotetext{
${ }^{86}$ LG Koln 02.04.1959 - 34 Qs 76/59; NJW 1959, 1598, at 1598-99.

${ }^{87}$ LAG Niedersachsen, 15.09.1993; 5 Sa. 1772/92 (A patient's medical records were revealed to non-medical staff of a hospital, the plaintiff managed to recover $6000 \mathrm{DM}$ in damages.

${ }^{88}$ BVerWG, 08.05.1970 - BVerWG VII ER 207.69. In this case, the plaintiff, previously a psychiatric patient, failed to obtain a driver's license owing to the fact he had an acute psychosis while in Frankfurt in the mid-60s. His appeal failed.

${ }^{89}$ BGH, 31.05.1983 - VI ZR 259/81, para. 17 and 28.

${ }^{90}$ Watelet et Dallet c. Min. Publ., Cour de Cass.; Dall. Per. 1886 I 347, at 347-348. In this case, two physicians were convicted for a breach of professional (medical) confidentiality by revealing the history of illness and cause of death of Jules Bastien-Lepage, a French painter. The story was published in a local paper, La Matin. The doctors were fined upon a criminal code provision and their appeal was unsuccessful. The Art. 378 of the French Criminal Code criminalised the divulgement any professional secret, be it a confessionary or a medical one. Concerning the early meaning of the statute, see Min. Publ. c. Berton, Trib. Corr. De la Seine, Mai 19, 1900, Dall. Per. 1901 II 81, p. 81-82 and note: the case was concerning a priest, but the note gives a comprehensive description of any divulgement of secrets, including medical ones. Concerning the medical secrets of personal records belonging to newborn children, see OLG Bayern, 07.02.1996 - 1 Z BR 72/95.

${ }^{91}$ Cass. 14 juin. 1965, Procureur General Pries La Cour de Bruxelles c. Dresse et Deflorenn, Pas. 1965. I 1102, 1103; on the criminalization of the breach of professional secrets (under Art. 478 of the Belgian Criminal Code), see older jurisprudence: Cass. 20 fevrier 1905, Procureur General a Bruxelles, a Charge d'Inconnus, Pas. 1905 I 141, 142-143; Albert Muller, Cass. 1 juillet 1912, Pas. 1912 I 367, 369.

${ }^{92} Z$ v Finland, [1997] 25 EHRR 371.
} 
records, while collecting evidence that the treatment that had been proscribed for their neonatal child, hadn't been performed at all. The hospital refused to furnish the records and the plaintiff took the matter to court. The court granted an order to allow the plaintiff access to the health records, finding that the couple's right to information derives from the contract of treatment. ${ }^{93}$ In a 1978 decision from Gottingen, the plaintiff was operated upon to remove his thyroid gland in 1975, but during the operation his vocal cords were severely injured. He subsequently commenced a negligence action and requested that his photocopied medical records and x-rays be examined by an appointed doctor. The defendants claimed that the medical records had been seized in the course of a preliminary investigation. The court expressed a dictum that not all information, but only treatment information should be supplied to the plaintiff, in order to avoid causing him psychological harm. The court, however, rejected the proposition that laymen are not entitled to see the documents, as the plaintiff could employ a skilled advisor to interpret them.

The seizure of documents was also found to be an unacceptable excuse, as the relevant record could also have been checked within the course of the investigation at the prosecutor's office. The court decided for the plaintiff, noting that there may be cases when the doctor may believe that some information may even cause the plaintiff to commit suicide if reviewed, but this was not the case. ${ }^{94}$ Surprisingly, in its 1982 decision, the Supreme Court found that the German legal and medical literature opposed the patient's right to insight, though the courts declined to follow the concept elaborated and discussed by the 1970 s authors. ${ }^{95}$ In a late 1970 s judgment from Limburg, a couple requested access to the hospital records of their neonatal child's treatment, but were denied. The court ruled that the defendant hospital's actions impaired the plaintiffs' right to self-determination; the contractual right to examine medical documents lies in the sphere of the patient's personal responsibility, and it is the patient's responsibility to contend with all the risks of disclosure. The court also augmented that the case before the tribunal did not come under the purview of "flattering consequences". Concerning the exceptions, the court noted that they may concern either the chances of recovery, or may derive from a special treatment contract provision, or may alternatively originate from a separate agreement. Therefore the court decided for the plaintiff and held that the defendant had no legitimate interest in obstructing the examination of the records. ${ }^{96}$ In a 1979 Bremen decision, the plaintiff sought access to records in order to file a medical malpractice suit, and the court affirmed his right to insight; concerning the "detrimental effects", the court determined that they were basically the "other side" of the "personlichkeitrecht", and there were no grounds for concealing the information, at least regarding the specific case. The court recognised that the inspection of hospital records is actually a form of

\footnotetext{
${ }^{93} A G$ Weltzar, 15.08.1978 - 3C 707/78, (para. 8-9; 15).

${ }^{94}$ LG Gottingen, 16.11.1978 - 2 O 152/78, para. 9-16.

${ }^{95}$ See BGH, 23.11.1982; VI ZR 222/79, para. 10; for an example, see Daniels (1976) at 348-349.

${ }^{96}$ LG Limburg, 17.01.1979 - 3 S 244/78, para. 7-8; 10; 13 (key points).
} 
"informational self-determination", in the same mode as informed consent to treatment. ${ }^{97}$

The scope and limits of the right to access were firmly designed by two surprising 1980s judgments: a 1981 decision in Cologne, and the Supreme court's 1982 decision. In the first instance, the plaintiff was a woman who had been under the defendant's treatment repeatedly since 1969 . He had already removed her right breast in order to address carcinoma in 1975. In 1979 the plaintiff was diagnosed with liver cancer. The defendant repeatedly missed check-ups and the plaintiff blamed the defendant for failure to detect her cancer earlier. In order to prove this, she requested the medical history recorded in 1975-79, but was denied. She petitioned the court to either: a) grant her access to records, or b) take photocopies of all the records; c) allow her or her representative to inspect her health records. ${ }^{98}$ The defendant claimed there is no legal basis to request the production of the records. The court held that in any case where a patient has a firm legal interest, the access may be granted, and noted that indeed there may be some medical records that may not be shown to the plaintiff, but to another person "subject to secrecy" (i.e. another physician). ${ }^{99}$ The court firmly rejected the claim that laymen may find the information in medical records incomprehensible, stating that even if this were the case, a plaintiff may consult lawyers or other physicians to clarify complicated data. The court also firmly denied that insight into medical records may affect the adequate handling of the data by physicians. ${ }^{100}$ The court added that there may a claim of secrecy in certain situations, e.g. if third parties' data is involved, but this was not the case. Moreover, the defendant's fear that the plaintiff would use the records to consult with an unsuitable professional was ungrounded, as it is the plaintiff's right to decide whom to consult with. The court decided in favour of the plaintiff. ${ }^{101}$ Interestingly, in this ruling the Cologne court stringently opposed the position of the English court in the case of Davidson v. Lloyd Aircraft Services Ltd. In that case, the plaintiff, a liaison engineer, had contracted tropical malaria and a number of further health complications that caused him to be unable to work. The plaintiff attempted to file an action against his employer, an English aircraft company that had let him go to Zanzibar without proper vaccinations. ${ }^{102}$ There, the English court firmly denied the plaintiff's right to direct insight to the medical records, insisting, inter alia, that laymen are unable to understand them properly. However, this and the earlier 1970s judgments were overruled by the McIvor judgment in $1978 .^{103}$

In the Supreme Court's 1982 judgment, the facts were somewhat similar. In 1976 the plaintiff underwent an operation on his cervical cord to prevent its further constriction and stop the progressing paralysis. After the operation he didn't feel

\footnotetext{
${ }^{97}$ OLG Bremen, 31.07 .1979 - 1 U 47/79, para. 15-et seq.(key points). Concerning the rule of informed consent, the Court cited the leading case of the Federal Supreme Court: BGH, 16.01.1959 - VI ZR 179/57.

${ }^{98}$ OLG Koln, 12.11.1981, 7U 96/81, para. 1-8 (facts).

${ }^{99}$ OLG Koln, 12.11.1981, 7U 96/81, para 18; 20.

${ }^{100}$ OLG Koln, 12.11.1981, 7U 96/81, para. 24-25.

${ }^{101}$ OLG Koln, 12.11.1981, 7U 96/81, para. 27; 29-30.

${ }^{102}$ Davidson v Lloyd Aircraft Services Ltd., [1974] 1 W.L.R. 1042, 1043-1044.

${ }^{103}$ McIvor v Southern Health \& Social Service Board, [1978] 1 W.L.R. 757, 760-761.
} 
better, but instead the paralysis worsened. While preparing a negligence lawsuit he attempted to obtain his treatment records. The plaintiff employed a lawyer and a physician to assist him. The defendant claimed: 1) he would not let plaintiff's lawyer examine the health records; 2) it may affect property rights in the medical records; 3 ) the revelations may be detrimental to the patient. ${ }^{104}$ The court ruled that the plaintiff generally had a right to access deriving from the contract, but it was necessary to examine and determine its precise scope. ${ }^{105}$ The Supreme Court affirmed that the right to insight is contractual by nature, and originates from the patient's right to self-determination and dignity, as a patient is not a mere object of treatment, and has a number of basic rights concerning his treatment. ${ }^{106}$ In a similar manner to the Cologne tribunal in the decision described above, ${ }^{107}$ the court came to the following conclusions: 1) it is not true that all laymen (herein the patients) cannot comprehend medical information, and if this is the case, they may ask for professional advice; property rights or copyrights in the medical records do exist, but they may surrender to "personlichkeitrecht", the personal rights of the patient involved; 2) the "detrimental effect" (at least in cases akin to this one) may surrender to the right to self-determination despite the negative consequences that may occur if the patient examines the records (though, as the Limburg court denoted, the patient, by accessing records, takes all risk upon himself) 3) hence, the only known restriction is the "patient-physician privilege" which may be hardly applicable to most cases; 4) the court acknowledges that there may be communications between doctors concerning patients that may not be accessible or subject to revelation, as they may contain subjective language or alleged diagnoses - generally speaking, information not intended for patient insight. However, that is not the case in this instance and, in general, is neither frequently requested nor mentioned; Thus, the court ruled that the plaintiff may have a right to access his medical records, limited only to scientific findings. ${ }^{108}$

\section{Complications with Psychiatric Records}

There are some types of medical records that are deemed highly confidential by their nature, much more than ordinary health records. For instance, the US courts held that HIV-status records, ${ }^{109}$ donor lists ${ }^{110}$ and psychiatric records ${ }^{111}$ are highly confidential. German judges have confirmed the same position as well. ${ }^{112}$

\footnotetext{
${ }^{104} B G H, 23.11 .1982$; VI ZR 222/79, para. 1-5 (trial facts).

${ }^{105} B G H, 23.11 .1982$; VI ZR 222/79, para. 14-15.

${ }^{106} B G H, 23.11 .1982$; VI ZR 222/79, para. 15-16.

${ }^{107}$ OLG Koln, 12.11.1981, 7U 96/81, para. 18-27.

${ }^{108} B G H, 23.11 .1982$; VI ZR 222/79, para. 17-27; 30.

${ }^{109}$ Doe v. Roe, 155 Misc. 2d 392, 397; 588 N.Y.S. 2d 236, 240 (1992).

${ }^{110}$ However, in cases where a person (plaintiff) was contracted with AIDS by blood transfusion, the identity of the blood donors and other personal data (e.g. addresses, basic medical records) may be disclosed upon a court order. See Tarrant County Hospitals v. District v. Hughes, 734 S.W.2d 675, 678-680 (Tex. App. - Fort Worth 1987); Boutte v. Blood Systems Ltd, 127 F.R.D. 122, 125-126 (1987); Stenger v. Lehigh Valley Hospital Center, 609 A.2d 796, 803 (1992). This position of several American courts is far from being omnipresently recognised.

${ }^{111}$ Indeed, in some American jurisdictions, psychiatric records were even bound to be disclosed upon a subpoena: In $\operatorname{Re} B, 394$ A. 2d 419, 425-426 (1978) [per curiam]. However this approach was
} 
In the Supreme Court's 1984 ruling, the plaintiff was treated at a closed psychiatric asylum in 1965 . He believed that he was put there in the course of some criminal investigations, seemingly unknown to him previously. After nearly twenty years, he desired to check his medical records. By the time the trial commenced, the plaintiff's symptoms had already been gone for over a decade. The regional court permitted the access but the defendant appealed; affirming the right to access, the court held that insight may be limited, depending on the type of plaintiff's disease or his actual health condition. While the records the plaintiff had requested were psychiatric ones, that didn't mean they were explicitly exempt from review. The defendant didn't express any adequate objections, demonstrating simple unwillingness instead; upon the appellate court's assessment, it was determined that the revelation might not affect the plaintiff's health in any way; thus, the court reaffirmed the judgment, emphasizing that a physician's objections must be grounded and justified, and not on mere speculations, but on facts and conclusions. $^{113}$

The Supreme Court's judgment from 1988 also touched upon the problems of insight into psychiatric records based on the chances that the plaintiff's symptoms may reoccur. The plaintiff, a former psychiatric facility patient, requested the hospital to produce his medical records involving his treatment in 1976-1981, having had a brief insight of these records in the presence of a physician prior to the lawsuit. But after he was twice hospitalised in 1986 and 1987, his application was withdrawn, as the physicians determined that the insight might worsen his health condition. Therefore the plaintiff lodged his lawsuit. In this case, the plaintiff did not actually desire to examine regular treatment facts, such as the results of medical examinations, he was interested in what doctors thought of his condition. The court affirmed his actual right to inspection, but noted that the right may be considerably reduced to psychiatric data. The court ruled that disclosure of the requested information may cause the patient's mental condition to deteriorate or that the patient may mistakenly communicate the findings to other physicians who may treat or consult him. ${ }^{114}$ The court argued that a physician has a right to restrict the available records to those with 'therapeutic' aspects. At the same time, psychiatric records themselves are not strictly inaccessible. However, in case of subsisting hypochondria, the access to records may be restricted on the basis of this fact, meaning it may be disclosed to an appointed medical advisor, or a fellow physician, or not to be disclosed to the plaintiff in detail. In the abovementioned case, the court found that access to the requested information might cause the plaintiff paranoia. Finally, the court ruled to grant the plaintiff access to the records, but only in the presence of a treating physician, who would explain the information found in the records. ${ }^{115}$

not uniform. See Ceasar v. Mountanos, 564 F2d. 1064, 1068-1069 (1978). The state of Pennsylvania recognised the right to privacy in psychological test results in a child custody litigation, over the necessity to disclose them to other parties involved, see In Re T.R., 731 A.2d. 1276, 1280-1282 (1999).

${ }^{112} B G H, 06.12 .1988$ - VI ZR 76/88, para. 7

${ }^{113} B G H, 02.10 .1984$ - VI ZR 311/82, originally reported at 5-8.

${ }^{114} B G H, 06.12 .1988$ - VI ZR 76/88, para. 3, 4-7 (facts).

${ }^{115} B G H, 06.12 .1988$ - VI ZR 76/88, para. 9-10. 
In a later judgment from Saarbrucken, the plaintiff desired to access his health records regarding previous psychiatric treatment. He desired not only ordinary records, but to obtain facts of "evaluative nature" and other details of his treatment, claiming these were required for his employment and for receiving insurance. This request was denied. Though the court confirmed his secondary contractual right in access, psychiatric records are quite restricted in their nature. Thus it is possible that in separate instances, the claimant, though not bearing an obligation to demonstrate a legal interest in purveying health records, may be requested to justify the reasons for disclosure. Taking into account that the plaintiff in this matter had already been employed and did not explain the reasons for his request for access at the trial (e.g. a need to commence a malpractice action or something similar), the court dismissed the appeal. ${ }^{116}$

Occasionally, the right to inspect medical records may be transferred to the heirs of the deceased person concerned. As I mentioned in my recent paper on data privacy and banking secrecy, several Continental Europe states, namely Germany, Austria, Switzerland and Liechtenstein have transferred the right to inspect a deceased person's banking records to all their heirs. ${ }^{117}$ The Supreme Court's 1983 decision cast a light on this complicated issue. The plaintiffs were the widow and daughter of a man who was unsuccessfully treated in the mid- to late 1970s, having suffered from appendicitis, inflammatory conditions of his lungs, pleura and an abdominal cavity outlet infection. The patient presumably died in late 1978 and the heirs, after having suspected malpractice, contacted a medicine negligence centre to determine the cause of death and, if malpractice was confirmed, to sue the hospital for damages. The surgeon of the negligence centre requested the medical records to make a verdict, but the hospital firmly refused to divulge the medical records. ${ }^{118}$ The court determined that the plaintiffs were not conventionally obliged to demonstrate a legal interest in insight, and that a patient's death shouldn't deprive them of such right. The court asserted that there are property rights within the right to inspect records, since the heirs had a well-understood legal interest in defining the cause of death, and if negligence was proved, to sue for damages, stating that the property rights of the deceased patient are transferred to his heirs with his presumed consent. The court added, however, that the "transfer" derives from secondary contractual rights, not in the sense of bequeathing ordinary property. ${ }^{119}$ The court also stated that the issue of medical confidentiality in this case should be properly clarified. In fact, as a general rule, medical confidentiality is bound to be breached without the implied or explicit consent of the patient, or in some exceptional circumstances. The court found that the heirs may have a right to access unless the deceased had, at some point, forbidden it, ${ }^{120}$ claiming that the contractual right to inspection may be somehow "transferrable", and the determination of the cause of death may be justifiable to "relational" access. In such cases the will of the deceased must be taken into

\footnotetext{
${ }^{116}$ LG Saarbrucken, 20.09.1995 - $16 \mathrm{~S}$ 1/93, see key points at para. 7-8.

${ }^{117}$ Lytvynenko (2019b) at 311.

${ }^{118} B G H, 31.05 .1983$ - VI ZR 259/81, para. 2-6 (facts).

${ }^{119} B G H, 31.05 .1983$ - VI ZR 259/81, para. 9; 12.

${ }^{120} B G H, 31.05 .1983$ - VI ZR 259/81, para. 13-14; 17;18.
} 
account, but not absolutely; according to the court, medical secrecy, as such, is not an acceptable justification for denying access to medical data. Thus, the court found that a right to insight of close relatives as heirs may allow the breach of medical confidentiality if properly justified. Based on this, the court found in favour of the plaintiff and the case was remanded. ${ }^{121}$ In a later judgment from Essen, the relatives of a deceased patient were granted the right to access to his medical records, hoping to discover the cause of his demise (and, if negligence was confirmed, to file a wrongful death suit), based upon a contractual right to insight; as another aspect of their action, nearly all medical records were unreadable, and the court affirmed their right to inspect the entries in a conceivable form. $^{122}$

\section{Summary and Hints for the European Court of Human Rights}

In both Anglo-Saxon and Continental legal systems, the courts recognise that a patient has a right to inspect their medical records either in the course of prelitigation (or after commencing a malpractice suit), or for their own private purposes. What general rules may be derived from the German jurisprudence in trials akin to Gaskin, Martin, Odievre or Godelli? Following are some conjectural ideas:

a) The property rights in the hospital records belong to the physician or hospital, but these rights are qualified to the patient's rights, ${ }^{123}$ and the German jurisprudence held that the patient also possesses property rights in their medical records; ${ }^{124}$

b) In non-psychiatric cases, the detrimental effect of examining medical records is considerably minimalised, though not completely void. At the same time, the right to self-determination in its informational component stringently means that the plaintiff should be prepared to behold the facts at their own risk; ${ }^{125}$

c) It is incorrect to assume that laymen are not intelligent enough to comprehend at least a part of their medical records. ${ }^{126}$ At the same time, they are free to choose any advisors they might necessitate, and it is unacceptable for a physician or hospital to withhold the production of files based upon the argument that the records may be transferred to an incompetent or in some way unreliable person; this is with the patient's autonomous discretion;

d) The physician and the hospital cannot object to the production of medical records merely by their own desire. Any objection must be justified and

\footnotetext{
${ }^{121} B G H, 31.05 .1983$ - VI ZR 259/81, para. 19-20; 25; 28; 30.

${ }^{122}$ A G Essen, 21.04.1997 - 12 C13/97, para. 5-6.

${ }^{123} B G H, 23.11 .1982$; VI ZR 222/79, para. 17.

${ }^{124} B G H, 31.05 .1983$ - VI ZR 259/81, para. 9.

${ }^{125}$ LG Limburg, 17.01.1979 - 3 S 244/78, para. 8-9.

${ }^{126}$ OLG Koln, 12.11.1981, 7U 96/81, para. 24.
} 
the defendant is expected to be ready to prove their objection at trial. ${ }^{127}$ Such objections, as the inability of the plaintiff to conceive the writings, are not accepted by the courts: ${ }^{128}$

e) Psychiatric records, being highly confidential, are restricted in access, but are not exempt from the right to inspection with limitations deriving from specific circumstances.

f) The contract-originating right to access may be transferred to a decedent's heirs in case they display a legal interest in insight, and the deceased person hadn't objected, at some point, to disclosing this information to their closest relatives. ${ }^{129}$

g) Plaintiffs who are maintained in psychiatric institutions or penitentiaries must not be deprived of the right to insight, but the fact of their confinement may impose additional rules of access, or limited disclosure of facts, or an inspection of the records by specially appointed professionals. ${ }^{130}$

h) Concerning trials commenced to grant access to medical records in adoption cases, the European Court strives to strike a balance in two directions: 1) between the privacy rights of the offspring and the birth parent; 2) the legislative balance establishing at least some remedy, such as access to anonymised records. ${ }^{131}$

The value of the said records is, however, doubtful. At the same time, I believe that the given "tests" must be augmented. France, Italy and other states recognizing a "right to anonymous birth" possess at least some jurisprudence upon which exceptions are frequently laid down. As the case law in "civil law" legal systems primarily derives from various statutes (laws, decrees and civil or other code provisions), bare code provisions without jurisprudence will not give an explicit landscape of what is the law concerning a particular subject.

\section{Conclusion}

In conclusion, it seems that the progressive development of law lies in jurisprudence, or case law. The principle of precedence is both successfully disposed in both Commonwealth and Continental legal systems. The jurisprudence of the ECHR is still relatively young and developing. For these reasons, the jurisprudence of various states is a perfect source for elaborate general rules in complicated actions that are brought before the European Court. Therefore, the given paper was devoted to a review of German jurisprudence on the subject of access to medical records. The author shares a thought that the analysis of national jurisprudence is quite sufficient to develop general rules of adjudicating cases that are brought before international human rights courts.

\footnotetext{
${ }^{127} B G H, 06.12 .1988$ - VI ZR 76/88, para. 7-10.

${ }^{128}$ LG Gottingen, 16.11.1978 - 2 O 152/78, para. 15; OLG Koln, 12.11.1981, 7U 96/81, para. 24.

${ }^{129} B G H, 31.05 .1983$ - VI ZR 259/81, para. 18; 20.

${ }^{130}$ See OLG Karlsruhe, 26.03.2007 - 2 Ws 322/06, para. 4; 11-et seq.

${ }^{131}$ Godelli v Italy, [2012] ECHR 374, para. 50; 54-56.
} 


\section{References}

Bulletin officiel du Ministère de l'intérieur, 1904 I 273 at gallica.bnf.fr/ark:/12148/bpt6k 55339232/f13.image

Crane, A.E. (1986) Annual Survey of American Law, at 645.

Daniels, J. (1976). 'Die Ansprüche des Patienten hinsichtlich der Krankenunterlagen des Arztes', in NJW 1976:345-349.

Demont, L. (2000). 'Secret medical et instance judiciare' 'Secret medical et instance judiciare', Rev. Juridique de l'Quest ( $N^{\circ}$ Spécial 2000 75-100.

Deutsch, E. (1992). 'Das Persönlichkeitsrecht des Patienten' in Archiv für die civilistische Praxis, 192(3):161-180.

Dworkin, G. (1979). 'Access to Medical Records - Discovery, Confidentiality and Privacy' in Modern Law Review 42(1):88-91.

Feenan, D. (1996). 'Common Law Access to Medical Records' in Modern Law Review 59(1): 101-110.

Harpst, R.J. (1962). 'Ownership of X-Rays' in Clev.-Marshall L. Rev. 11(2): 272-278.

Lytvynenko, A.A. (2019a). 'Common Law Right to Access to Medical Records: The Commonwealth and European Court of Human Rights Practice', $7^{\text {th }}$ International Conference of PhD Students And Young Researchers: "Law 2.0: New Methods, New Laws", Vilnius, Lithuania.

Lytvynenko, A.A. (2019b). 'Data Privacy and Banking Secrecy: Topical issues in Commonwealth, Continental Europe and International Jurisprudence', in Athens Journal of Law 5(3):303-322, Doi=10.30958/aj1.5-3-5.

Passion, L. (1983). 'Législation et prophylaxie de l'abandon à Paris au début du XXème siècle' in Histoire, économie \& société 2(3):475-496.

Wischnath, M. (1998). 'Einführung zu den Bewertungs- und Erschließungsempfehlungen für Krankenakten' in Der Archivar, Jg. 51 (2): 233-244.

\section{Cases}

\section{European Court of Human Rights}

B.F.B. Villa-Nova v Portugal, [2015] ECHR 1049

Gaskin v United Kindgom (1989) 12 EHRR 36

Godelli v Italy, [2012] ECHR 347

GSB v Switzerland, [2015] ECHR 1122

Khehili v Switzerland, [2011] ECHR 195

Leander $v$ Sweden [1987] 9 EHRR. 433

MG v United Kindgom, App. 39393/98, judgment of 29 Sept. 2002

Odievre v France, [2003] F.C.R. 621

Roche $v$ United Kingdom [2005] ECHR 956

Rotaru v Romania, [2000] ECHR 92

$S$ \& Marper. United Kindgom, [2008] ECHR 1581

Szulc. Poland, [2013] 57 EHRR. 5

$Z v$ Finland, [1997] 25 EHRR 371 


\section{$\underline{\text { Australia }}$}

Breen v. Williams, [1996] H.C. 78

\section{Austria}

OGH 23.5.1984, 1 Ob 550/84

\section{$\underline{\text { Belgium }}$}

Cass. 1 juillet 1912, Albert Muller, Pas. 1912 I 367

Cass. 14 juin. 1965, Procureur General Pries La Cour de Bruxelles c. Dresse et Deflorenn, Pas. 1965. I 1102

Cass. 20 fevrier 1905, Procureur General a Bruxelles, a Charge d'Inconnus, Pas. 1905 I 141

\section{Canada}

Lamothe v. Mokleby \& Erle Holdings Co., 106 D.L.R. (3d) 233 (1979)

McInerney v. Macdonald, [1992] 2 S.C.R. 138

Re Mitchel \& St. Michael's Hospital, 112 D.L.R. (3d) 360 (1980)

\section{Federal Republic of Germany}

AG Essen, 21.04.1997 - 12 C13/97

AG Neunkirchen, 28.10.1991, 5 C 648/91

AG Weltzar, 15.08.1978 - 3C 707/78

$B G H, 11.04 .1956$ - VI ZR 20/55

$B G H, 16.01 .1959$, VI ZR $179 / 57$

$B G H, 23.11 .1982$; VI ZR 222/79

$B G H, 31.05 .1983$ - VI ZR 259/81

$B G H, 02.10 .1984$ - VI ZR 311/82

$B G H, 20.02 .1985$ - 2 StR 561/84

$B G H, 06.12 .1988$ - VI ZR 76/88

BVerfG, 16.09.1998 - 1 BvR 1130/98

$B V e r W G, 25.09 .1958$ - BVerWG WDB 9/58

BVerWG, 08.05.1970 - BVerWG VII ER 207.69

LAG Niedersachsen, 15.09.1993; 5 Sa. 1772/92

LG Gottingen, 16.11.1978 - 2 O 152/78

LG Koln 02.04.1959 - 34 Qs 76/59; NJW 1959, 1598

LG Limburg, 17.01.1979 - 3 S 244/78

LG Saarbrucken, 20.09.1995 - 16 S 1/93

OLG Bayern, 07.02.1996 - 1 Z BR 72/95

OLG Bremen, 31.07.1979 - 1 U 47/79

OLG Hamm, 23.02.2012 - 1 Vollz (Ws), 653/11

OLG Karlsruhe, 36.03.2007 - 2Ws 322/06

OLG Köln, 12.11.1981, 7U 96/81

OLG Munchen, 19.04.2001 - 1 U 6107/00 


\section{$\underline{\text { France }}$}

Mallet, 16 Sept. 1843, Cour de Cass.; Ch. Crim., Sirey 1843, I 915

Min. Publ. c. Berton, Mai 19, 1900, Trib. Corr. De la Seine, Dall. Per. 1901 II 81

Romieux c. Min. Publ, 1 Juin 1844, Cour de Cass.; Ch. Crim., Sirey 1844 I 669

Watelet et Dallet c. Min. Publ., Cour de Cass.; Dall. Per. 1886, I 347

\section{United Kingdom}

England

Church of Scientology v DHSS, [1979] 1 W.L.R. 723.

$D v$ NSPCC, [1978] A.C. 171.

Davidson v Lloyd Aircraft Services Ltd., [1974] 1 W.L.R. 1042.

Deistung v South West Metropolitan Regional Hospital Board, [1974] 1 W.L.R. 213.

Dunning v United Liverpool Hospitals' Board of Governors, [1973] 1 W.L.R. 586.

In Re D (Infants), [1970] 1 W.L.R. 599.

McIvor v Southern Health \& Social Service Board, [1978] 1 W.L.R. 757.

R. v Mid Glamorgan Family Health Services Authority \& Another/Ex Parte Martin, [1995] 1 W.L.R. 110.

Scotland

Boyle v Glasgow Royal Infirmary and Associated Hospitals, 1969 SC 72; 1969 S.L.T. 137.

\section{United States of America}

Boutte v. Blood Systems Ltd, 127 F.R.D. 122 (1987).

Ceasar v. Mountanos, 564 F2d. 1064 (1978).

Cannell v. Medical and Surgical Clinic, 315 N.E.2d 278 (1974).

Clay v. Little Co. of Mary Hospital, 277 Ill.App.3d 175; 213 Ill.Dec. 866; 660 N.E.2d 123 (1995).

Doe v. Roe, 155 Misc. 2d 392; 588 N.Y.S. 2d 236 (1992).

Hoyt v. Cornwall Hospital, 169 Misc. 361 (N.Y. 1940).

Humphers v. First Interstate Bank, 298 Or. 706; 696 P. 527 (Or. 1985).

In Re B., 394 A. 2d 419 (1978).

In Re June 1979 Allegheny County Grand Jury Investigation, 415 A.2d 73 (1979-80).

In Re T.R., 731 A.2d. 1276 (1999).

In re Weiss, 147 N.Y.S 2d. 455 (1955).

Kirsch v. Parker, 383 So. 2d 384 (La. 1980).

Massey v. Parker, 369 So. 2d 1310 (La. 1979).

Rabens v. Jackson Park Hospital Foundation, 40 Ill.App.3d 113; 351 N.E.2d 276 (1976).

Stenger v. Lehigh Valley Hospital Center, 609 A.2d 796 (1992).

Tarrant County Hospitals v. District v. Hughes, 734 S.W.2d 675 (Tex. App. - Fort Worth 1987). 